\title{
PLANT VIRUS INHIBITORS FROM MARINE ALGAE
}

\author{
by \\ KEITH PARDEE \\ B.Sc. (spec.), The University of Alberta, 1996 \\ l \\ A thesis submitted in partial fulfillment of \\ the requirements for the degree of
}

MASTER OF SCIENCE

in

THE FACULTY OF GRADUATE STUDIES

(Department of Botany)

We accept this thesis as conforming

to the reauired standard

The University of British Columbia

November 2001

(CKeith Ian Pardee, 2001 
In presenting this thesis in partial fulfilment of the requirements for an advanced degree at the University of British Columbia, I agree that the Library shall make it freely available for reference and study. I further agree that permission for extensive copying of this thesis for scholarly purposes may be granted by the head of my department or by his or her representatives. It is understood that copying or publication of this thesis for financial gain shall not be allowed without my written permission.

Department of Botrany

The University of British Columbia

Vancouver, Canada

Date Decenber 13/2001 


\begin{abstract}
This study was the first to evaluate new world algal species for compounds with potential for plant virus chemotherapy. Methanolic extracts from 30 species of marine algae were assayed for antiviral activity against potato virus $\mathrm{X}$ (PVX) in local lesion assays using Chenopodium quinoa L. as host. Extracts from six algal species (Fucus gardneri Silva, Alaria nana Schrader, Ralfsia sp. (Berkley), Codium fragile (Suringar) Hariot, Fragilaria oceanica Cleve, Egregia menziesii (Turner) J.E. Areschoug) inhibited PVX infectivity by more than $80 \%$, with a disproportionate number of these extracts coming from the phylum Heterokontophyta. Of the six most active extracts, it is the first time that Fucus gardneri, Ralfsia sp. and Fragilaria oceanica have been reported as sources of antiviral agents. Antiviral activity from the most potent extract, $F$. gardneri, was selected for phytochemical analysis. Fractionation of the crude extract resulted in the isolation and identification of the polysaccharide alginate as a source of bioactivity. Alginate inhibited potato virus $\mathrm{X}$ infectivity by $95 \%$, and preliminary transmission electron microscopy indicates that the mode of action may be related to aggregation of virus particles. Bioactivity in a second fraction was the result of phenolic and amino-based compounds that have yet to be positively identified.
\end{abstract}




\title{
TABLE OF CONTENTS
}

\author{
Abstract \\ List of Tables \\ List of Figures $\quad$ vi \\ Acknowledgements viii \\ Chapter 1: Introduction to the Field 1 \\ $\begin{array}{ll}\text { Bibliography } & 17\end{array}$
}

Chapter 2: Screening Marine Algae for Antiviral Activity

$\begin{array}{ll}\text { Introduction } & 20\end{array}$

Species List 29

Methods and Materials $\quad 40$

Results 45

$\begin{array}{ll}\text { Discussion } & 50\end{array}$

Bibliography $\quad 57$

Chapter 3: Fractionation of Antiviral Compounds from Fucus gardneri

Introduction 62

$\begin{array}{ll}\text { Methods and Materials } & 68\end{array}$

Results $\quad 85$

Discussion $\quad 99$

Summary and Conclusions 112

$\begin{array}{ll}\text { Bibliography } & 114\end{array}$

Appendix 1 


\section{LIST OF TABLES}

Table 2.1: Major classical algal phyla.

Table 2.2: Algal phyla based on classical taxonomy and molecular sequence information.

Table 2.3: Potato virus $Y$ isolates.

Table 2.4: Local lesion antiviral assay from algae screening.

Table 2.5: Inhibition of TMV $-\mu 1$ by select algal extracts.

Table 2.6: Percent PVX inhibition tested, using a local lesion assay on Chenopodium quinoa, over a logarithmic dilution series of four crude extracts.

Table 2.7: Anti-PVX activity of select algal extracts 4 months after extraction.

Table 2.8: Effects of crude and semi-pure fractions of Fucus gardneri extract were tested against PVX-infected Solanum tuberosum culture.

Table 3.1: Percent inhibition of PVX infectivity in LLAs by extracts from two different solvent extractions over a time course.

Table 3.2: Percent bioactivity of compounds isolated from preparatory-TLC bands.

Table 3.3: Percent inhibition of PVX infectivity in LLAs by groups of fractions collected from silica column $(S i-1)$.

Table 3.4: Percent inhibition of PVX infectivity of fractions collected before and after heat treatment and diazo-methylation of crude Fucus gardneri determined using LLAs.

Table 3.5: Percent inhibition of PVX infectivity in LLAs of fractions collected from Amberlite XAD-2 column chromatography $(A-1)$. 
Table 3.6: Percent inhibition of PVX infectivity of fractions collected from Sephadex LH-20 column chromatography $(\mathrm{Se}-\mathrm{I})$.

Table 3.7: Percent inhibition of PVX infectivity from silica column chromatography $(\mathrm{Si}-2)$ of the ethyl acetate fraction from liquid partitioning of crude Fucus gardneri extract.

Table 3.8: Percent inhibition of PVX infectivity in LLAs by fractions collected from Sephadex LH-20 column chromatography ( $\mathrm{Se}-2)$ of silica column (Si-2) fractions (53-78).

Table 3.9: Percent inhibition of PVX infectivity in LLAs by fractions collected from Amberlite IR-120 column chromatography (A-2).

Table 3.10: Percent inhibition of PVX infectivity in LLAs from fractions collected from Polyamide column chromatography $(P-I)$ of fraction A of Sephedex LH-20 chromatography (Se-2).

Table 3.11: Percent inhibition of PVX infectivity of crude polysaccharide fractions collected in a serial extraction of Fucus gardneri.

Table 3.12: Percent inhibition of PVX infectivity of commercially prepared polysaccharides. 


\section{LIST OF FIGURES}

Figure 2.1: Transmission electron micrograph of potato virus $\mathrm{X}$ particles.

Figure 2.2: Lesion development on Chenopodium

quiona in local lesion assay.

Figure 2.3. Collection site Whiffin Spit, Vancouver Island.

Figure 2.4: Potato tissue culture after 30 days of chemotherapy.

Figure 3.1: Fucus gardneri found growing densely on intertidal rocks of North Pacific coast.

Figure 3.2: Flow diagram of serial polysaccharide extraction of Fucus gardneri.

Figure 3.3: Silica preparatory thin-layer chromatogram of crude Fucus gardneri extract.

Figure 3.4: Silica thin-layer chromatogram of crude and methylated Fucus gardneri extracts.

Figure 3.5: Fluorescence image of electrophoresis of fraction A in SDS-PAGE.

Figure 3.6: Thin-layer chromatogram of acid hydrolysed fraction B, crude fraction B and glucose sugar standard.

Figure 3.7: Transmission electron microscopy images of PVX particles after incubation in the test solutions.

Figure 3.8: Thin-layer chromatography of hydrolysed alginate standard and active fractions from Sephadex G-100 chromatography.

Figure 3.9: Flow diagram of methods used leading to the isolation of fraction A and B from Sephadex LH-20 column chromatography (Se-2). 
Figure 3.10: Summary of methods and results from the characterization of Fraction A.

Figure 3.11: Summary of methods and results from the characterization of Fraction B. 


\section{ACKNOWLEDGMENTS}

My sincerest thanks go to both of my supervisors. Dr. Chris French for his encouragement, patience and his willingness to allow me to explore new ideas. Dr. Neil Towers also for his encouragement, creativity and wonderful stories. I would like to thank the entire committee, which also included Drs. Iain Taylor and Jim Hudson, for their advice along the way and their efforts in the writing of this thesis.

Many thanks also go to Zyta Abramowski, Mike Boutihillier, Dr. Dong Sheng Ming, Felipe Balza and Rene Orozco for their assistance in and out of the lab. I am also grateful to members of the Towers Lab and the Department of Botany including: Andres Lopez, Kevin Usher, Aniko Varga, Fiona Cochrane, Eduardo Jovel, Brian Hillhouse and Patrik Inderbitzin for advice and friendship.

This research was supported by the Science Council of British Columbia in the form of two years of scholarship to the author. Agriculture Canada also supported this project in the form of funding to the author during the summer of 1999 and a lab operating budget through Dr. Chris French. As well, the Natural Sciences and Engineering Research Council of Canada provided support through operating and equipment grants to Dr. Neil Towers.

Finally, I would like to thank my partner, Una Dowey, for her patience and unwavering support throughout. 
This thesis is dedicated to my

Family 


$$
\text { Cbapter } 1
$$

\section{Introduction to the Field}

\section{All that we do is touched with ocean, yet we remain on the shore of what we know...}

-Richard Wilbur, former U.S. poet laureate

\section{Background}

As agriculture has developed into an intensive and global industry, plant virus outbreaks and chronic infections have become increasingly frequent and disruptive (Thresh, 1983). Economic and social costs resulting from such crop pathogens call for better means of either virus prevention or control (Bos, 1999). Traditionally the agricultural industry has looked toward synthetic chemistry to solve problems of crop disease and fertility. However, natural chemical diversity is playing an increasing and integral role in the search for novel and alternative agrochemicals (Wedge and Camper, 2000). Plant viral chemotherapy is currently an effective strategy used to fight plant virus infection, however problems with phytotoxicity limit its application (Hansen, 1989). Exploiting natural chemical diversity to meet the demand for alternative, non-toxic plant antivirals presents an excellent opportunity for discovery of new products (Muller et al., 2000). The goal of this project is to evaluate the chemical diversity of selected British Columbian marine algae for antiviral activity against a plant virus, potato virus $\mathrm{X}$. 


\section{Agricultural Significance}

For many plant virologists, it is the agricultural significance of viruses that ultimately drives most lines of investigation. Plant viruses are very important crop pathogens, second in importance only to fungi, and result in annual losses in the billions of dollars (Matthews, 1991). The effects of infection are manifested in a variety of ways. The most obvious is often a reduction in growth that is frequently accompanied by lower crop productivity. Plant virus infection can also affect crop quality. Changes in chemical composition such as sweetness or taste, color, and size can all lead to losses for the grower. As is the case with some human viral infections, plant viruses may also increase host vulnerability to stress. By reducing vigor, viruses can leave crops vulnerable to opportunistic infections, competition, drought or frost. An example of the scale of potential social and economic consequences is provided by the cacao swollen shoot badnavirus in West Africa. Between the discovery of the disease in the 1930's and its control in 1977, Ghana alone lost over 160 million cacao trees (Bos, 1999). More recently, pepino mosaic virus has emerged as a new crop pathogen for tomato growers in both Europe and North America. Although economic impacts to date have been negligible, the threat of the virus jumping into more important solanaceous crops like potato is significant (EPPO, 2001). Given the impact viruses have on the economics and trade of agricultural products there is clearly a need for practical alternatives to prevent or curtail infections. 


\section{Plant Viruses}

Viruses are difficult to define but are unique in almost all respects. Not only are they very small in size and simple but their means of replication, translocation and transmission set them apart from all other pathogens. Their ability to cause disease, carry genetic material and reproduce suggests behavior characteristic of other microorganisms. However, in other respects viruses resemble complex chemical molecules in that they are essentially lifeless outside host organisms. In their most basic form viruses are composed of nucleic acid, either RNA or DNA, surrounded by a protective capsule of protein and, in some groups, an additional membrane. The nucleic acid may exist in either single or double stranded configuration, although for plant viruses the most common form of genome is positive single-stranded RNA (Matthews, 1991). The simplicity of viruses however imparts limitations to their natural history. For viruses to perform any metabolic function they must associate with the cellular machinery of another organism, and it is in the process of doing so that viruses can cause disease. The symptoms that are recognized as a disease are often the result of virus particles disrupting host cellular function, consuming cellular resources and occupying cellular space (Agrios, 1997).

\section{DISCOVERY OF VIRUSES}

Viruses and other cellular parasites such as viroids are the most recent class of plant pathogens to be discovered (Hansen, 1989). One of the earliest well 
documented reports of viral disease in agriculture dates back to seventeenth century Holland. Although at the time not known to be caused by a virus, tulips infected with the tulip breaking potyvirus were highly prized for their colorful and streaked petals (Walkey, 1991). The true start of plant virology began in the late $19^{\text {th }}$ century with the identification and characterization of the first virus, tobacco mosaic virus (TMV), by Beijerinck. (1898). This new class of transmissible agents became known collectively as filterable viruses, because they could easily be passed through ceramic filters designed to remove bacteria (Bos, 1999). Over time the definition of a virus has become refined to differentiate viruses from other cellular parasites, such as Rickettsiae, Chlamydiae and Mycoplasmas. Matthews (1991) defines viruses as:

"A virus is a set of one or more nucleic acid template molecules, normally encased in a protective coat or coats of protein or lipoprotein, that is able to organize its own replication only within suitable host cells. Within such cells, virus replication is (i) dependent on the host's protein-synthesizing machinery,

(ii) organized from pools of the required material rather than by binary fission, (iii) located at sites that are not separated from the host cell contents by a lipoprotein bilayer membrane, and (iv) continually giving rise to variants through various kinds of change in the viral nucleic acid."

\section{VIRAL TRANSMISSION}

Inactive outside of their host organisms, plant viruses must rely on outside mechanisms for dispersal and transmission. The discovery, in 1883 , that 
leafhopper insects could transmit rice dwarf disease was the first time that viral transmission was demonstrated (Zaitlin and Palukaitis, 2000). Since then, plant viruses have been found to be transmissible by many different means. Of the 997 plant viruses known, many can be transmitted to successive generations through seed, pollen and vegetative propagation; this is known as vertical transmission (Bos, 1999). Intermediate organisms can also facilitate viral transmission; fungi, bacteria, invertebrates and vertebrates including humans often serve as vectors for plant viruses; this is known as horizontal transmission (Matthews, 1992). The unintentional spread of viruses through human activities such as grafting, vegetative propagation, mechanical damage and global trade are often important contributors to plant virus epidemics. In fact, epidemiological studies have found human activity is a leading cause of plant virus outbreaks (Thresh, 1983). An example of such is the outbreak of plum pox potyvirus in the Niagara Peninsula, Ontario in 2000 (CFIA, 2001). It is thought that infected rootstock was imported into Canada and once in the country, aphids may have transmitted the virus to adjacent orchards. Ultimately all infected orchards may have to be destroyed and replanted with virus-free trees or alternative crops (Cree, 1999). Such outbreaks are not infrequent and their occurrence demonstrates the value of surveillance of imports and early detection in the field.

\section{Detection \& Diagnosis}

The development of improved methods for the detection and characterization of plant viruses has been of immeasurable importance to this 
field. Prior to the development of serological and molecular techniques, determination of suspected viral agents relied on using indicator hosts, testing transmissibility to indicator species, host range, cross protection tests and description of cytological effects (Matthews, 1991). The development of the local lesion assay by Holmes in 1929 permitted for the first time the determination of virus infectivity. Although this technique is limited by sensitivity, it is still the only method that can discriminate between viable and nonviable plant virus particles (Zaitlin and Palukaitis, 2000). The development of serology and reverse transcriptase polymerase chain reaction (RT-PCR), has led to applications such as immuno-labeling and molecular screening using virus-specific primers. These methods have considerably advanced characterization in plant virology (Walkey, 1991; James et al., 1997). For the purposes of this study, diagnostic needs were met using local lesion assays and enzyme linked immunosorbent assays (ELISA).

\section{Control Measures}

Despite the importance of viruses in crop pathology there are few methods available to prevent infection. To compound the situation for growers, there are no practical field methods for treating virally infected crops (Bos, 1999). The most common and successful approach to virus control is prevention. On a global scale, regulatory measures such as quarantine and inspection help to limit the spread of viruses (Agrios, 1997). In the field, preventive measures include crop rotation, greenhouse and field hygiene, limiting mechanical damage and the 
removal of symptomatic plants and related taxa that may serve as virus reservoirs. Biological control of vectors, planting of barrier crops to intercept vectors and planting with certified virus-free seed are other passive measures available to growers (Matthews, 1991, 1992). The last method raises a key point, for passive controls to be effective the crop must first be free of infection.

\section{Production of Virus-free Plants}

For vegetatively propagated crops, such as potato or fruit trees, viral infections are often a persistent problem because viruses may spread to successive generations through the propagules themselves. However, once the cycle is broken, crops can often be maintained virus-free for several growing seasons. Obtaining virus-free foundation stock from which propagules are generated can be achieved using a number of approaches (Matthews, 1992).

\section{Traditional Methods}

Early methods took advantage of individual plants that were naturally virus-free because of either geographic isolation or chance. Although seemingly inadequate, this method successfully provided for early potato and fruit tree cultivation (Hansen, 1985). Since 1950, heat therapy has been used successfully to rid plant material of viruses. Using this method, dormant or growing plants are exposed to above average temperatures (usually $35-54^{\circ} \mathrm{C}$ ) for a period of weeks (Matthews, 1991). Viral suppression achieved using heat therapy can be attributed to the disruption of viral multiplication. At temperatures above optimum, viral 
multiplication is reduced while viral degradation and plant growth continue. This can lead to the production of virus-free tissue that can be used to establish foundation stock. However, low plant survival, host intolerance, viral resistance and length of the process limit the practical application of heat therapy (Hansen, 1985).

An alternative approach to obtaining virus-free tissue is meristem tip culture (Walkey, 1991). This technique takes advantage of a natural phenomenon which for some viruses leaves the apical $100-500 \mu \mathrm{m}$ of many shoots virus-free (Matthews, 1991). It has been hypothesized that this phenomenon is the result of either cell division exceeding the rate of viral synthesis or cell division outcompeting viruses for resources. Despite its value in eradicating certain viruses, recalcitrant infections and practical limitations such as manipulation of the meristem and poor regeneration make meristem culture best suited for application in combination with other techniques (Hansen, 1989).

\section{Breeding Resistance}

Breeding crops with resistance to plant viruses provides a completely different approach to this problem by preventing rather than treating infection. Originally this was achieved by introducing genes for resistance, tolerance or hypersensitive response into cultivars through crossbreeding. The hypersensitive response can prevent systemic infection by confining the proliferation of viruses to the site of entry. Unfortunately because of breeding limitations, expression of these traits into agriculturally important crops generally failed (Walkey, 1991). 
However when successful, this strategy has proven to be sound. As an example, the breeding of virus resistant sugarbeet cultivars in response to emerging viruses has repeatedly prevented the collapse of the sugar industry in North America. With the introduction of molecular techniques over the past decade, development of virus resistance cultivars is no longer restricted by reproductive compatibility (Bos, 1999).

\section{Genetically Engineered Resistance}

Electroporation, gene-gun and other molecular techniques now allow free shuffling of genes not only between species but also between kingdoms. By overcoming limitations of generation time and breeding incompatibility, molecular advances have revolutionized the process of developing resistant cultivars. The most common approach for achieving plant virus resistance in this field is a technique called coat-protein-mediated virus resistance (Bos, 1999). DNA complementary to viral coat-protein genes is introduced and expressed in crop plants. The concept comes from a process called cross-protection. Crossprotection refers to resistance acquired by a plant following a mild viral infection, much like vaccination. By mechanisms not fully understood, once a plant is infected subsequent exposure to the same or a related virus does not result in disease (Miller and Hemenway, 1998).

Genetic engineering techniques have opened up many possible strategies for reducing crop pathogenesis. Examples specific to potato viruses include resistance acquired through transformation with a natural antiviral protein gene 
from pokeweed and a protease gene from potato virus $\mathrm{Y}$. Both of these genes result in the expression of enzymes that confer antiviral protection to the transformed potato (Kaniewski and Lodge, 1992; Jilka and Tumer, 1996). However, issues over public and environmental safety of genetically modified organisms have raised concerns over the use of transgenic plants in agriculture. Other factors slowing the application of this approach include the large investment required to develop resistant cultivars. Unlike other methodologies, most developments in this field are by their very nature specific to each host-virus combination making cost recovery more difficult (Matthews, 1992). Generally speaking, ethical and proprietary issues as well as concerns over long-term effectiveness have made genetically engineered solutions less desirable at present.

\section{Plant Virus Chemotherapy}

Intervention against viral infection can take three forms: avoidance, prophylaxis, and post-infection treatment (Rozhon et al., 1994). To this point all major antiviral strategies have been reviewed with one important exception, viral chemotherapy. Plant virus chemotherapy offers a further approach to providing virus-free plants for agriculture. Chemotherapy does not have the advantage of genetic resistance that genetic engineering offers, however it also does not carry the disadvantages. Over the past 50 years, plant virus chemotherapy has grown from a string of serendipitous observations into a field with substantial outcomes and potential for further improvement. Promising directions for plant viral 
chemotherapy include the identification of new effective but non-phytotoxic antivirals and plant defense stimulators (Walkey, 1991; Klarzynski et al., 2000). Currently, plant viral chemotherapy is not practical for field applications. Much like meristem culture and heat therapy, chemotherapy is generally performed under laboratory conditions to the tissues of desirable but infected cultivars (Walkey, 1991). It acts by slowing virus multiplication such that new tissues grown while under therapy are virus-free and can be used to establish uninfected foundation stock (Hansen, 1989).

In contrast to the number of antibiotics available for treating bacterial infections, there are few comparable treatments for viral infections. The intimate association between virus replication and host metabolism poses a problem for the development of viral chemotherapy in both plant and animal systems. Unlike many pathogens, viruses have an internal, obligate relationship with their hosts, depending on host cellular processes for all activity. Consequently, drugs that are intended to inhibit viral function often also act against cellular processes resulting in toxicity to the host (Rozhon et al., 1994).

Difficulty in identifying specific viral targets for drug action and an incomplete understanding of infection and replication processes, at one point made the development of successful viral chemotherapy unlikely (Neushul, 1990). However, in 1961 Quak successful demonstrated in a series of thiouracil treatments that chemotherapy could not only prevent virus replication but could do so without severely affecting cell metabolism. Her strategy was to minimize 
phytotoxicity by using viral inhibitors specific to RNA metabolism (Quak, 1961). To date the most successful plant viral chemotherapeutic compound is a synthetic uracil analogue specific to RNA metabolism, called ribavirin. This compound, also known by the name Virazole, is effective against many viruses including those of animals (Hansen, 1988). However because some cellular distuption still occurs, inhibition by ribavirin is often accompanied by phytotoxic effects including: stunted growth, irregular foliage and limited root development (Bos, 1999). Similarly, DHT (2,4-dioxo-hexhydro-1,3,5-triazine) can reduce losses incurred due to viral infection, however it appears to be unable to eradicate the virus entirely (Hansen, 1988). Resolution of these problems may be found through combination therapy as is increasingly being done with human viruses. By combining two or more therapeutics, the individual concentration of each compound can be reduced and their combined modes of action act together to further challenge the infection (Hansen, 1988).

Resolving the demand for alternative non-toxic antivirals remains a high priority in applied virology. Both pharmaceutical and agrochemical discovery processes are largely geared toward synthetic compounds. This in part is an artifact of the industry's heavy reliance on high throughput screening (HTS) to identify new leads (Muller et al., 2000). This is because HTS is well suited to simple extracts like those produced by combinatorial chemistry, but is essentially incompatible with the complexity of natural extracts. Furthermore, difficulties inherent with purification and structural elucidation also contribute to dominance of synthetic 
therapeuticals; however, advances in automation are making natural chemical diversity more accessible (Grabley and Thiericke, 1999).

Although it is difficult to argue the success of the HTS, this method has disadvantages, an important one being the nature of the substance pool. Evidence suggests that from a strategic point of view, drug and agrochemical research require greater focus on evaluation of natural products. By focusing screening programs strictly on compounds of synthetic origin, particularly from combinatorial chemistry, substantial forms of chemical diversity may be overlooked. Analysis shows that approximately $40 \%$ of chemical diversity found in natural products is not available through traditional synthetic approaches (Muller et al., 2000). Furthermore synthesis of highly complex molecules, such as taxol, is simply impractical for screening programs. Consequently, screening programs based on natural products are essential. Natural product screening programs extend the range of available chemical diversity, thus complementing existing programs focused on compounds of synthetic origin.

\section{Natural Products and Their uses}

Once considered to be incidental by-products of metabolism, secondary metabolites are now recognized as mediators of herbivory, competition and a host of other ecological interactions. A sort of chemical warfare appears to have evolved between groups of organisms. As one group would produce a noxious chemical the other would develop detoxifying mechanisms or tolerance. In some cases this has resulted in plants having suites of redundant defensive compounds. 
Similar strategies are found in other organisms, particularly invertebrates such as insects or sessile organisms such as sponges (Wedge and Camper, 2000). Natural products that are identified as having valuable bioactivity for human use do not necessarily have a corresponding role in the organism from which they come. Rather societies have simply found an alternative use for naturally occurring chemical diversity (Hansen, 1989)

Chemical diversity, generated by such things as defense mechanisms, has been exploited by humans for millennia. India and China are two well-known examples of cultures that relied heavily on plant-based medicine; however, it can probably be said that until recently this was the case for all cultures (Grabley and Thiericke, 1999). Some well-known plant-based medicines are morphine from Papaver somniferum and quinine from the Peruvian Cinchona officinalis tree. Isolation of such active principles during the early part of the 1800 's led to the development of the modern day pharmaceutical industry. More recent examples of natural product based drugs are the anticancer agent, taxol, and the immunosuppressant, FK 506 (Grabley and Thiericke, 1999). The first record of a natural product used to combat plant virus infection dates back to 1925. Duggar and Armstrong found several plant extracts, which curtailed TMV infections in tobacco. Natural products remain a source of bioactive compounds for agriculture. Examples of recent agrochemicals to come out of natural product research include: insecticidal avermectins from Streptomyces avermitilis and a 
new class of non-phytotoxic agro-fungicides based on the fungal metabolites strobilurin and oudemansin (Anke and Steglich, 1999).

\section{Natural Products as Viral Inhibitors}

Demand for novel, biologically active structures is encouraging chemists to exploit natural chemical diversity (Wedge and Camper, 2000). Although not inherently better than synthetically derived compounds, natural products as mentioned can augment screening programs by providing chemical diversity and variation not easily accessible to synthetic chemistry. The trend towards including natural products in screening programs is becoming apparent in the pharmaceutical market where " $60 \%$ of approved drugs and pre-new drug application candidates were of natural origin for the period 1989 to 1995 " (Grabley and Thiericke, 1999). Furthermore, in 1996 drugs based on natural products accounted for $\$ 79$ billion of the $\$ 227$ billion market in new pharmaceuticals (Muller et al, 2000). To date only a handful of natural productbased antivirals, such as Neem (Azadiracta indica) and Boerhaavia diffusa, have been put into practical agricultural applications (Hansen, 1989). Considering the chemical diversity only available through natural products and the minor extent to which such diversity has been exploited, future work in this area is bound to yield discovery. 


\section{GoALS AND OBJECTIVES}

A combination of research capability and proximity to the Pacific coast makes screening organisms from the marine environment for antiviral activity a natural partnership. There were two main objectives of this research project. The first objective was to screen 30 selected marine algae for antiviral agents against the plant virus potato virus $\mathrm{X}$. The second objective was to select from the most antiviral extracts a candidate for more detailed characterization. Fucus gardneri, the most potent marine algal extract, was selected. Detailed study of this extract included evaluation for bioactivity against local and systemic PVX infection and phytochemical analysis. 


\section{BIBLIOGRAPHY}

Agrios, G.N. 1997. Plant diseases caused by viruses. In: Plant pathology 4th edition. Edited by: Agrios, G.N. Academic Press. Toronto. pp. 479-560.

Anke, T. and Steglich, W. 1999. Strobilurins and oudemansins. In: Drug discovery from nature. Edited by: Grabley S. and Thiericke R. Springer New York. pp. 302-323.

Beijerinck, M.W. 1898. Over een contagium vivum fluidum als oorzaak van de vlekziekte der tabaksblanden. Verhandel. Koninkl. Akad. Wetenchap., Afdel. Wis-Natuurk. 7:229-235. In: Matthews, R.E.F. 1991. Plant virology $3^{\text {rd }}$ Edition. Academic Press. Toronto. pp. 1-8.

Bos, L. 1999. Plant viruses, unique and intriguing pathogens: a textbook of plant virology. Backhuys Publishers, Leiden. pp. 5-19 \& 254-274.

CFIA (Canadian Food Inspection Agency). 2001. Plum Pox Virus Confirmed in Canada. www.inspection.gc.ca/english/corpaffr/newcom/20000623e.html

Cree, L.A. 1999. Plum Pox Potyvirus facts sheet. Canadian Food Inspection Agency. www.inspection.gc.ca/english/ppc/science/phra/plumpox/.html

Duggar, B.M. and Armstrong, J.K. 1925. The effect of treating the virus of Tobacco mosaic with the juices of various plants. Annals of the Missouri Botanical Garden. Xii, 4: 359-366. Summary found in: 1926 Review of Applied Mycology 5: 377-378.

EPPO (European and Mediterranean Plant Protection Organization). 2001. Pepino mosaic potexvirus. www.eppo.org/quarantine/alert list/Viruses?pzm$\underline{\text { xxx.html }}$

Grabley, S. and Thiericke, R. 1999. The impact of natural products on drug discovery. In: Drug discovery from nature. Edited by: Grabley, S. and Thiericke, R. Springer. New York. pp. 2-33.

Hansen, A.J. 1985. An end to the dilemma - Virus-free all the way. Hortscience 20: 852-859.

Hansen, A.J. 1988. Chemotherapy of plant virus infections. In: Applied virology research. Volume I: New Vaccines and Chemotherapy. Edited by: Kurstak, E., 
Marusyk, R.G., Murphy, F.A. and Van Ragenmortel, M.H.V. Plenum Press. New York. pp. 285-298.

Hansen, A.J. 1989. Antiviral chemical for plant disease control. Critical Reviews in Plant Science 8: 45-88.

James, D., Trytten, P. A., Mackenzie, D.J., Towers, G.H.N. and French, C.J. 1997. Elimination of apple stem grooving virus by chemotherapy and development of an immunocapture RT-PCR for rapid sensitive screening. Annals of Applied Biology 131: 459-470.

Jilka, J.M. and Tumer, N.E. 1996. Virus Resistant Plants Transformed with a PVY Protease Gene. US Patent No. 5,589,612.

Kaniewski, W.K. and Lodge, J.K. 1992. Virus Resistant Potato Plants. US patent No. 6,015,940.

Klarzynski, O., Plesse, B., Joubert, J.M., Yvin, J.C., Kopp, M., Kloareg, B., Fritig, B. 2000. Linear beta-1,3 glucans are elicitors of defense responses in tobacco. Plant Physiology 124: 1027-1037.

Matthews, R.E.F. 1991. Plant virology $3^{\text {rd }}$ Edition. Academic Press. Toronto. pp. $1-634$.

Matthews, R.E.F. 1992. Fundamentals of plant virology. Academic Press. Toronto. pp. 1-380.

Miller, E. D. and Hemenway, C. 1998. History of coat protein-mediated protection. In: Methods in molecular biology, Vol. 81: Plant virology protocols: From virus isolation to transgenic resistance. Edited by: Foster, G. D. and Taylor, S.C. Humana Press. Totowa. pp. 25-38.

Muller, H., Brackhagen, O., Brunne, R., Henkel, T. and Reichel F. 2000 Chapter 7 Natural Products in Drug Discovery. In: The role of natural products in drug discovery. Edited by Mulzer, J. and Bohlmann R. Springer. New York.

Neushul, M. 1990. Antiviral carbohydrates from marine red algae. Hydrobiologia 204: 99-104.

Quak, F. 1961. Heat treatment and substances inhibiting virus multiplication in meristem culture to obtain virus-free plants. Proceedings: $25^{\text {th }}$ International Horticultural Congress 1: 144-155. 
Rozhon, E., Albin, R., and Schwartz, J. 1994. Strategies for discovering antiviral agents from natural products. In: The discovery of natural products with therapeutic potential. Edited by: Gullo, V. Butterworth-Heinemann. Toronto. pp. 223-237.

Thresh, J.M. 1983. Plant virus epidemiology and control: current trends and future prospects. In: Plant virus epidemiology. Edited by: Plumb R.T. and Thresh J.M. Blackwell Scientific Publications. Boston. pp. 349-358.

Walkey, D.G.A. 1991. Applied plant virology $-2^{\text {nd }}$ Edition. Chapman and Hall. New York. pp. 3-8 \& 270-292.

Wedge, D.E. and Camper, N.W. 2000. Connections between agrochemicals and pharmaceuticals. In: Biologically active natural products: pharmaceuticals. Edited by: Cutler, S.J. and Cutler, H.G. CRC Press. New York. pp. 1-16.

Zaitlin, M. and Palukaitis, P. 2000. Advances in understanding plant viruses and virus diseases. Annual Review of Phytopathology 2000. 38:117-143. 
Chapter 2

\section{Screening Marine Algae for Antiviral Activity}

"The answers we are searching for on earth are to be found in the sea"

-Anonymous

\section{Introduction}

\section{SUMMARY AND OBJECTIVES}

Marine algae have received little attention as a source of chemical diversity in the search for non-toxic alternatives to current plant virus chemotherapeuticals. Marine ecosystems offer a largely untapped source of biological and chemical diversity, which over the past thirty years has yielded novel and unique bioactive compounds (Carté, 1996). Several workers have found that marine algae contain compounds with significant potential against human (Nakashima et al., 1987; Beress et al., 1993; Hudson et al., 1999a,b) and plant viruses (Galal et al., 1999; Padmakumar and Ayyakkannu, 1997). Although marine algae have been recognized as a source of bioactive compounds for several decades, it was not until 1997 that the rich flora in the coastal waters of British Columbia was screened for therapeutic value (Kim et al., 1997).

The goal of this study was to identify marine algae that contain non-toxic, antiviral agents for potential use in plant chemotherapy. Work on this project began after algal extracts in a small screening proved to have potent antiviral activity against potato virus $\mathrm{X}$. The study includes more than 30 species of marine algae, mostly macro-algae collected from the shores of Vancouver Island. 


\section{Marine Natural Products}

Appreciation for the potential of marine natural products as therapeutics began in the early part of the 1970s. Marine organisms continue to yield molecules of unique and unconventional chemical structure (McConnell et al., 1994). The reason that marine ecosystems are so richly endowed with chemical diversity is not fully understood, although the answer may lie in the role that oceans played during early evolution (Volkman, 1999). Marine environments gave rise to life on the planet and are home to many "primitive" organisms. It has been hypothesized that because these organisms often lack sophisticated immune systems, survival in such competitive environments requires diverse and often toxic defense strategies (Grabley and Thiericke, 1999).

The rationale behind the suggestion that these secondary metabolites play a defensive role is two-fold. First, synthesis of these structurally complex molecules is metabolically expensive and correspondingly it can be argued must be of some utility to the organism. Second, there is a strong correlation between these unique secondary metabolites and their occurrence in seemingly vulnerable soft-bodied organisms like algae and sponges (Pawlik, 1993). Such defense strategies are often based on metabolites that have very specific binding. This specificity is attractive to agrochemical and pharmaceutical industries, as they try to avoid nonspecific chemical interactions that lead to toxicity and are a chief cause of compounds failing to reach the market (McConnell et al., 1994).

Despite the promising outlook of marine-based therapeutics, the field is still in its infancy, with as yet no commercial products. Two interrelated issues are the main barriers to the development of this field. Most of the compounds identified as having potential for therapy are structurally complex and therefore do not lend themselves to synthesis (Jensen and Fenical, 2000). Secondly, isolating these compounds from natural sources is not realistic, because active 
metabolites often make up a minute fraction of the organism's fresh weight (Fusetani, 2000). This scenario is similar to the difficulties involved in the development of the anticancer drug, taxol. Although technical advances may provide some solutions to supply issues, algae remain with the distinct advantage that mariculture techniques can be easily adapted to provide reliable and renewable culture of algae with therapeutic value (Jensen and Fenical, 2000).

\section{MARINE ALGAL NATURAL PRODUCTS}

Seaweeds have long been used in agriculture as manures to improve soil fertility (Chapman, 1970) as well as foliar sprays to nourish and reduce crop stress (Blunden and Gordon, 1986). Marine algae however do not have the ethnobotanical heritage of many land plants (Chapman, 1970). The first modern report of biological activity coming from algal metabolites dates back to 1940 when extracts of Chlorella vulgaris were found to have antibiotic properties (Pratt and Fong, 1940). It was almost twenty years later before any algal metabolites were found to be antiviral (Gerber et al., 1958).

The emergence of viral chemotherapy is actually closely tied to marine natural product chemistry. The most successful class of both plant and animal antivirals, nucleoside analogs, are based on the discovery in the 1950s that arabinosides from sponges could be used therapeutically against viruses. Synthetic chemistry advanced this concept and led to the development of the two most successful antivirals: Ribavirin and Acyclovir. However only in the early eighties, with the beginning of systematic screening programs, were algae and other marine organisms screened comprehensively for antiviral activity (Rinehart $e t$ al., 1981). Statistically metabolites from marine organisms are also the leading source for anticancer bioactivity (Munro et al., 1987). Most research into the antiviral properties of marine algae has focused on members of the Rhodophyta and Heterokontphyta. Chlorophyta have not been closely evaluated for marine natural 
products largely because their metabolites are unstable and most species are tropical (Carté, 1996; Paul and Fenical, 1987).

Intensive phytochemical studies of algal antiviral agents began with the identification of the human immunodeficiency virus (HIV) in 1984. Algal metabolites that have since been implicated in antiviral activity against human infection include: sulphated polysaccharides, polyphenols, peptides, and sulfoglycolipids (Schaeffer and Krylov, 2000). As the surveys of marine natural products have widened, bioassays have become more diverse (Munro et al., 1987). Algal metabolites have been found to have bioactivity against human retroviruses, herpes viruses, togaviruses, paramyxovirues, thabdoviruses (reviewed in Schaeffer and Krylov, 2000), poliovirus (Hudson et al., 1999a,b) and plant tobamoviruses and necroviruses (Padmakumar and Ayyakkannu, 1997; Galal et al., 1999).

\section{Potato VIRUS $\mathrm{X}$}

Algae screened for bioactivity in this study were tested against the Potexvirus, potato virus $\mathrm{X}$, which is also known by the common names potato latent virus or potato mild mosaic virus. Particles are long flexous filaments with dimensions approximately 515 by $13 \mathrm{~nm}$ (Figure 2.1). The virus has a positive sense, single-stranded RNA genome and lacks a membrane envelope (Shaw, 1996). Symptoms in Solanum tuberosum depend on the strain but are generally mild, ranging from none to mild mosaic or necrotic streaking (Šutić et al., 1999). The strain used in this study as a model for screening and for bioassay-guided fractionation was a severe strain, originally isolated in Prince Edward Island, Canada. There are no natural vectors of PVX; transmission occurs by vegetative propagation, contact between infected plants or mechanically. PVX occurs in potato growing areas around the world; however, in many areas the virus no longer presents a threat to production (Brunt et al., 1996). PVX was chosen for this study because of viral stability and clear symptom development in indicator 
species. In nature the virus mainly infects members of the Solanaceae, however it can also be successfully replicated in a number of other hosts from the following genera: Amaranthus (Amaranthaceae), Brassica (Brassicaceae), Chenopodium (Chenopodiaceae), Euphorbia (Euphorbiaceae), Gomphrena (Amaranthaceae), Trifolium (Fabaceae) and Vitis (Vitaceae) (Šutić et al., 1999).

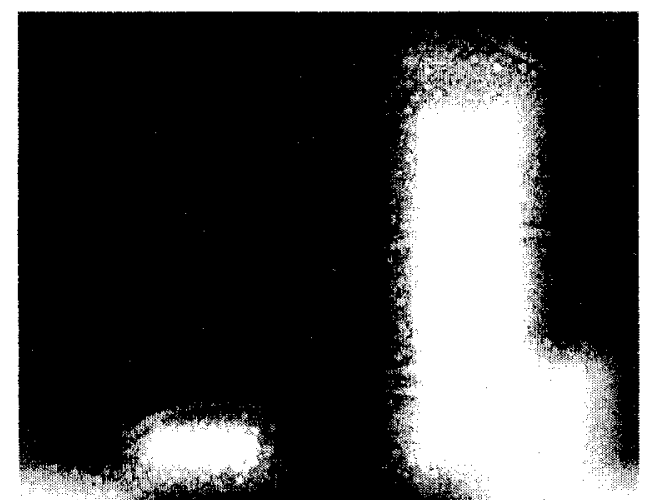

Figure 2.1: Transmission electron micrograph of potato virus $\mathrm{X}$ particles. Virus particles are long flexuous rods approximately $13 \times 515 \mathrm{~nm}$ (Source: University of Columbia in New York City, 2001).

\section{BIOASSAYS}

It is important in the design of a screening program to choose bioassays that reliably reconstruct the conditions of the infection to be treated. Fortunately when testing for agents against plant viruses, ethical constraints do not limit assays either in vivo or in the intended host. This provides some reassurance that antiviral compounds in the assay will have relevant activity within the host (Munro et al., 1987). The two bioassays used in this study were the local lesion assay and systemically infected potato tissue culture, which tested bioactivity of compounds against local and systemic infections, respectively. The latter assay was used to assess the most antiviral algal extract, which was obtained from Fucus gardneri, against established viral infection in $S$. tuberosum. Since $S$. tuberosum does not exhibit a hypersensitive response to PVX, infection is spread systemically producing no quantifiable lesions. Therefore the ELISA was used to 
detect and assay virus in the host. The design of this experiment was intended to reflect plant virus chemotherapy methods used by industry so that efficacy, absorption and toxicity of the extract could be more fully assessed.

Local lesion assays were invaluable to the project, allowing differentiation between viable and non-viable virus in the screening of algal extracts for bioactivity. Chenopodium quinoa was used as the host because of the clear countable lesions it produces in response to infective PVX particles. This assay relies on the hypersensitive response of such an indicator species to create foliar lesions in response to pathogen infection (Matthews, 1991). Two actions characterize a response. One is the necrosis of cells at and surrounding the entry point of the virus, this is the response that allows virologists to quantify virus infectivity (Figure 2.2). The other is a dramatic change in metabolism of surrounding cells, such as the creation of mechanical barriers, defense proteins and phytoalexins. These changes help to contain the spread of the virus by contributing to resistance in surrounding cells (Fritig et al, 1990). Local lesion assays can discern a difference in concentration of viable virus with a resolution of $10-20 \%$ (Matthews, 1991).

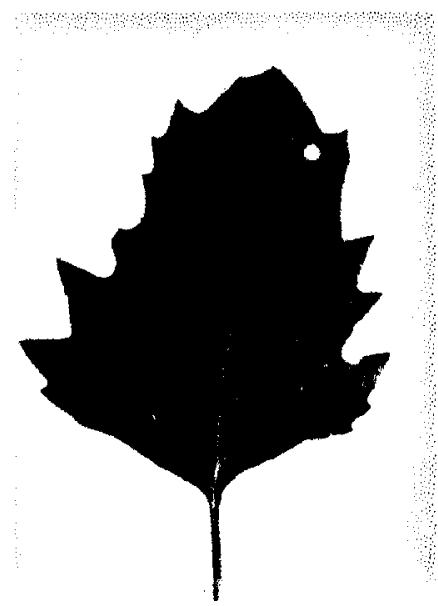

Figure 2.2: Lesion development on Chenopodium quinoa in local lesion assay. Treatment side (left) shows complete inhibition of PVX infectivity, while development of lesions on control side (right) indicates infective virus particles. 


\section{Marine Algae}

As primary producers, algae are extremely important to the global energy balance, contributing more than any other group to the world's biomass (Lee, 1999). Taxonomically they are a large and difficult to define group of organisms. This complexity comes from the fact that algae are polyphyletic; that is, they do not share a single common ancestor. The grouping is instead based on a shared form and function (Graham and Wilcox, 2000). Algae are thallophytes, plants without stems, leaves and roots, containing chlorophyll $a$ (Lee, 1999). Algae range in size from single cell diatoms to massive kelps over $40 \mathrm{~m}$ in length (Witvrouw and De Clercq, 1997). Most algae, including all in this study, are found in aquatic environments (Lee, 1999). Depending on the taxonomic scheme used to classify algae, they can be divided into eight or nine phyla. Traditionally this was done using accessory photosynthetic pigments and cell structure (Table 2.1) (Bold and Wynne, 1985). Recently, molecular techniques have essentially corroborated the existing classification, with only a few minor changes to the phylogenetic organization (Table 2.2) (Lee, 1999).

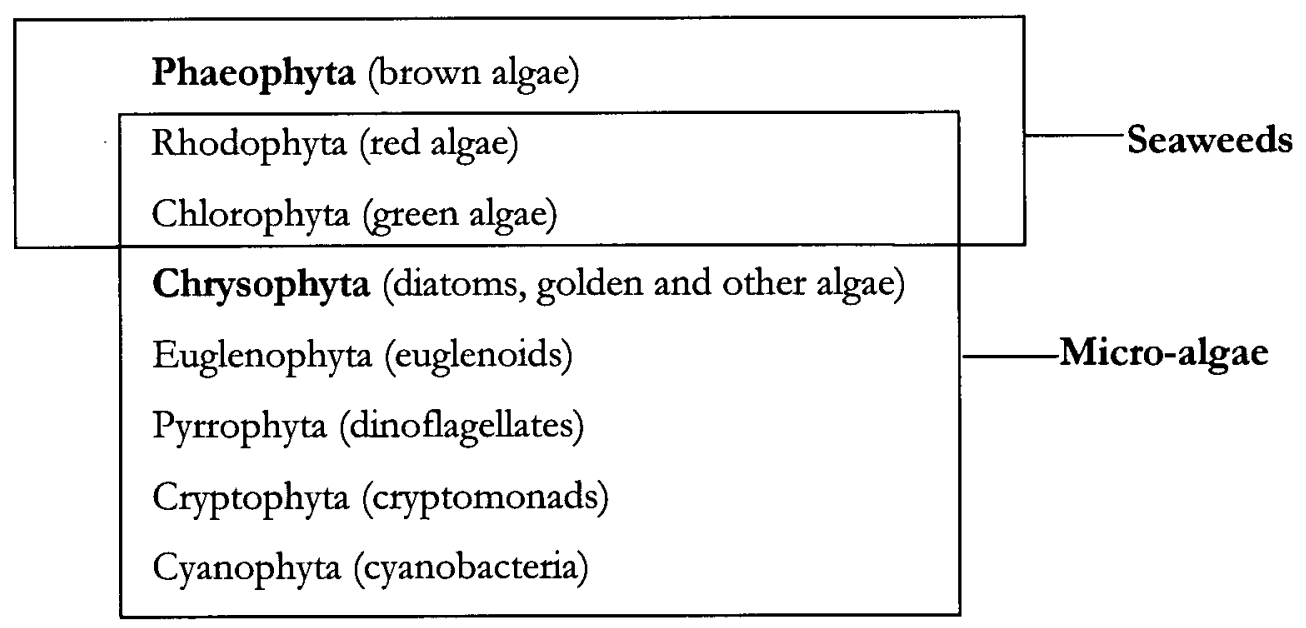

Table 2.1: Major classical algal phyla. Bold text refers to taxa that have since been grouped. (Adapted from Bold and Wynne, 1985) 
Heterokontophyta (Chrysophyceae, Synurophyceae,

Dictyochophyceae, Pelagophyceae, Bacillariophyceae,

Xanthophyceae, Eustigmatophyceae, Phaeophyceae)

Seaweeds

Rhodophyta (red algae)

Chlorophyta (green algae)

Prymnesiophyta (Chrysophyta)

Euglenophyta (euglenoids)

Micro-algae

Dinophyta (was Pyrrophyta)

Glaucophyta (chloroplasts are endosymbiotic

cyanobacteria cyanelle)

Cryptophyta (cryptomonads)

Cyanophyta (cyanobacteria)

Table 2.2: Algal phyla based on classical taxonomy and molecular sequence information. Bold text refers to newly formed taxa. (Adapted from Lee, 1999)

Based on the more recent classification, this study evaluated the bioactivity of algae from the Heterokontophyta, Rhodophyta and Chlorophyta (Table 2.2). Heterokont species evaluated in the screening belong to the brown algae and diatoms. This group is fundamentally different from the other algal divisions and consequently is classified in the Kingdom Chromista. Both Rhodophyta and Chlorophyta belong to the Kingdom Plantae. Specifically, members of the Heterokontophyta are distinguished from other algae by the presence of two heteromorphic flagellae, plastids encased with a fold of endoplasmic reticulum, chlorophyll $c$ but never $b$, and carotenoids such as fucoxanthin (Graham and Wilcox, 2000). Diatoms are strictly unicellular or colonial and are common in both fresh and salt water. The most notable feature of the diatoms is the siliceous frustule. This detailed and delicate covering protects the cells and provides key diagnostic features for identification (Van Den Hoek et al., 1995). In contrast, brown algae (Phaeophyceae) have no unicellular or 
colonial forms and reside almost exclusively in marine environments (Lee, 1999). The dark brown colour comes from accumulations of tannins and fucoxanthin that mask chlorophyll (O'Clair and Lindstrom, 2000). Members of the brown algae are dominant in the cold waters of the Northern and Southern Hemispheres such as coastal British Columbia, and are found abundantly in the intertidal and subtidal zones (Lee, 1999).

The Rhodophyta are more closely related to higher plants than brown algae and are also mostly found in marine environments ( $\mathrm{O}^{\prime} \mathrm{Clair}$ and Lindstrom, 2000). Their chemistry has been the most widely studied of the marine algae because of the abundance of halogenated compounds with high bioactivity (Carté, 1996). Although often red in color, varying amounts of the three primary pigments green chlorophyll, red phycoerythrin and blue phycocyanin lead to a wide range of coloration. These accessory pigments allow red algae to absorb green and blue light, thus permitting these algae to inhabit deeper reaches of the water column (O'Clair and Lindstrom, 2000). Red algae exist as a range of growth forms, from single cells or filaments to complex filamentous aggregations. As with the red algae Lithothamnium sp. and Corallina officinalis that were screened for PVX inhibition, the cell walls of some red algae are calcified. These particular red algae are called corallines and are especially common in warmer waters (Graham and Wilcox, 2000).

Green algae exist as either unicells or multicellular forms. As the name suggests the Chlorophyta are distinguished by the dominance of the bright green pigment chlorophyll. The Chlorophyta are the most diverse phylum of algae and most of its species (87\%) are found outside of marine environments. Evidence suggests that green algae (Charophycaceae) are the ancestors to modern land plants. Shared characters between green algae and higher plants include: chlorophyll pigments $a$ and $b, \alpha$ and $\beta$ carotenes, starch storage and in some cases cellulose. (O'Clair and Lindstrom, 2000). 
Below are descriptions of the taxonomy, habitat and structure for each of the species included in this study (Algaebase, 2001, O'Clair and Lindstrom, 2000; Hustedt, 1985; Scagel, 1967). The lifecycles of marine algae are complex and involve alternating generations between gametophyte and sporophyte. Since no general rules apply and some lifestages look identical while others are radically different, each species description is accompanied with a sketch.

\section{HETEROKONTOPHYTA}

Alaria nana Schrader

Order: Laminariales

Family: Alariaceae

Distribution: Cape Yakataga, Alaska to Oregon on exposed coasts

Bathymetry: mid-low intertidal

Description: A golden brown to olive color. Holdfast is large and with many rootlike haptera. Stipe is thick and cylindrical. Strap-shaped sporophylls just above holdfast. Above this point, stipe gives rise to conspicuous vegetative blade. Blade is up to $3 \mathrm{~m}$ long.

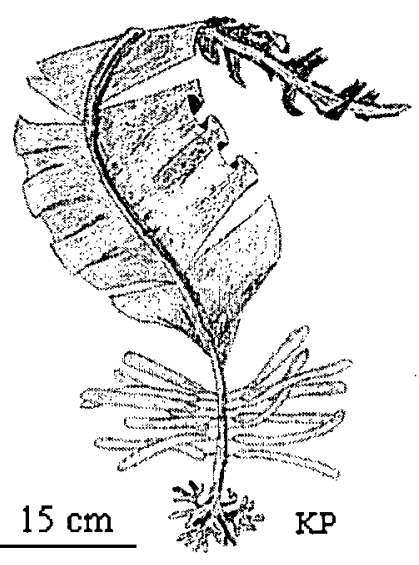

Colpomenia peregrina (Sauvageau) Hamel Order: Ectocarpales

Family: Scytosiphonaceae

Distribution: Alaska to central California, North

Atlantic, Australia, New Zealand

Bathymetry: low intertidal

Description: Yellow brown color. Globular, thin walled sacs. Tapered at base, no stipe and small holdfast.

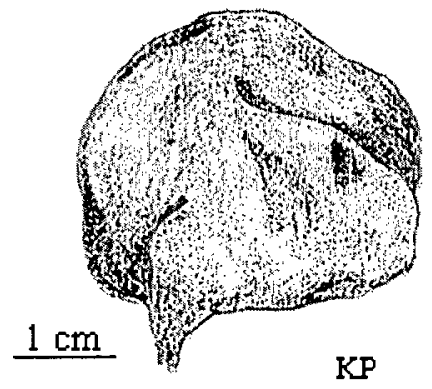


Costaria costata (C. Agardh) Saunders

Order: Laminariales

Family: Laminariaceae

Distribution: Unalaska Island, Alaska to southern

California, Japan and Russia.

Bathymetry: low intertidal and upper subtidal

Description: Yellow-brown to brown in color. Holdfast is branched and leads to a stipe with 5-7 parallel ribs. These ribs continue as the stipe widens into the blade that tapers at the top. Between ribs the blade is bullate.

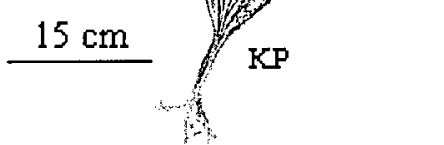

Cymathere triplicata (Postels \& Ruprecht) J. Agardh Order: Laminariales

Family: Laminariaceae

Distribution: Bering Sea to Northern Washington. Kurile Islands, Russia.

Bathymetry: low intertidal to upper subtidal.

Description: Yellow-brown in color. The holdfast is discoid and without branching. The stipe is short and leads to 3 ribs running the length of the undivided blade. Has a cucumber-like smell.

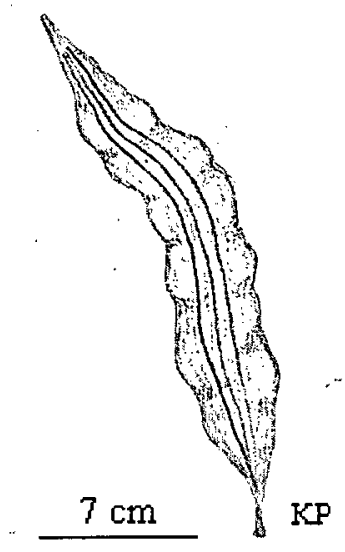

Egregia menziesii (Turner) Areschoug

Order: Laminariales

Family: Lessoniaceae

Distribution: Queen Charlotte Islands to Mexico.

Bathymetry: intertidal to shallow subtidal

Description: Dark brown to olive in color. Holdfast is branched and leads to a flattened stipe covered with papillae. It is branched irregularly with the sides of the branches being fringed with small blades and air bladders. (common name is feather boa kelp)

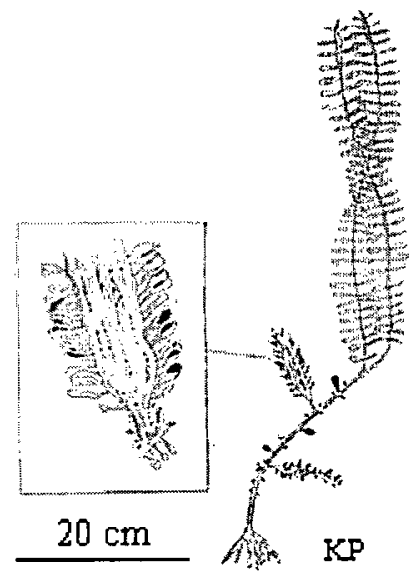


Fragilaria oceanica Cleve

Order: Fragilariales

Family: Fragilariaceae

Distribution: Northern Hemisphere

Bathymetry: mid to upper intertidal

Description: Colonial, forming dense ribbons of unicells. In valve view frustule is lanceolate $8-60 \mu \mathrm{m}$ long, 3-8 $\mu \mathrm{m}$ wide with delicate transapical straie. In girdle view rectangular and linear.

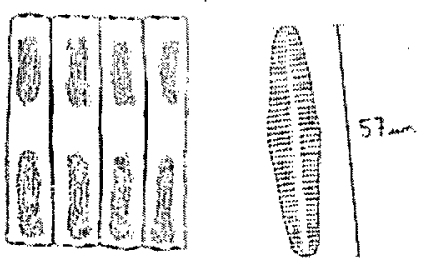

\section{Fucus gardneri Silva}

Order: Fucales

Family: Fucaceae

Distribution: Bering Sea, Alaska to central California,

Kamchatka

Bathymetry: upper to mid intertidal

Description: Brown to brown-olive color. Is often dominant in the mid intertidal. The holdfast is discoid and leads to flat, dichotomously branched blades.

Blades have percurrent midrib throughout. At the tips of blades are receptacles containing gametes.

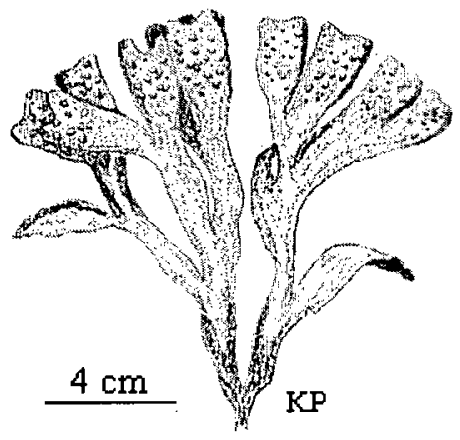

Hedophyllum sessile (C. Agardh) Setchell

Order: Laminariales

Family: Laminariaceae

Distribution: Aleutian Island, Alaska to Monterey

Country, California.

Bathymetry: mid to low intertidal

Description: Dark brown and prefers wave exposure. Very abundant at Whiffin spit collection site. The holdfast is finely divided and leads directly to the blade, with no stipe being present (very short stipe is present when young). The blade is fan shaped and has a pitted texture. As the

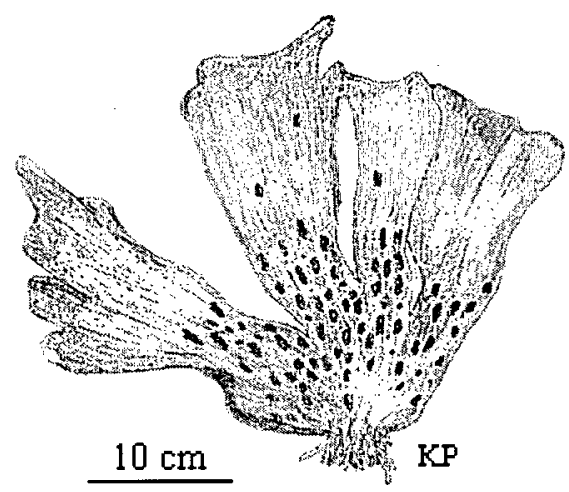
season passes the blade becomes very torn. 
Laminaria saccharina (Linnaeus) J. V. Lamouroux

Order: Laminariales

Family: Laminariaceae

Distribution: Aleutian Islands, Alaska to California; Japan; Arctic and North Atlantic.

Bathymetry: low intertidal to upper subtidal

Description: Brown to brown-olive in color. The conspicuous holdfast is branched and leads to a cylindrical stipe. The blade is smooth with slightly ruffled edges.

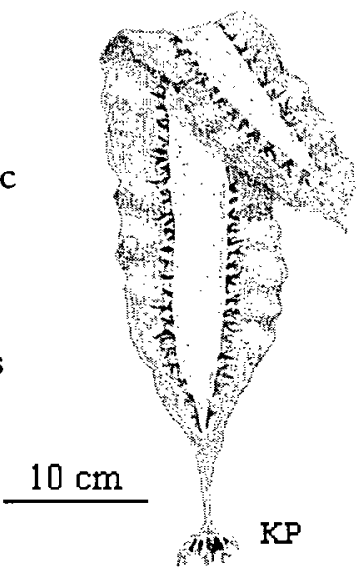

Nereocystis luetkeana (Mertens) Postels \& Ruprecht

Order: Laminariales

Family: Lessoniaceae

Distribution: Aleutian Islands, Alaska to

California

Bathymetry: Subtidal to $17 \mathrm{~m}$

Description: Brown in color. Is one of the largest brown algae. The holdfast is branched and can be as wide as $40 \mathrm{~cm}$ in diameter. The stipe makes up most of Nereocystis with the average length being about $10 \mathrm{~m}$. The upper end of the stipe is hollow and forms a tapered float. From the top of the bulb, two groups of blades (as many as 20) emerge. Often form thick beds

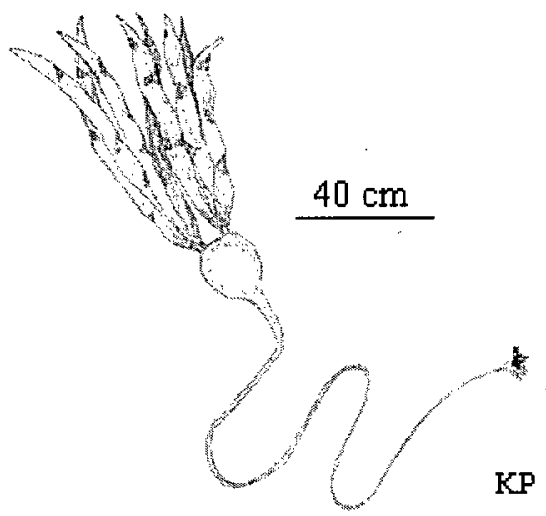
known as kelp forests.

Ralfsia sp. Berkeley

Order: Ralfsiales

Family: Ralfsiaceae

Distribution: Aleutian Islands, Alaska to Humbolt County, California; Arctic, North Atlantic

Bathymetry: middle to low intertidal

Description: Crustose algae, forming olive-brown circular patches 1-2 mm thick. Broadly overlapping lobes. Slow growing.

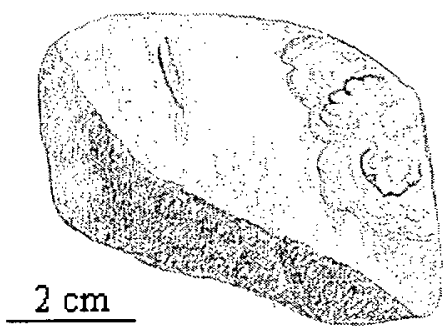


Soranthera ulvoidea Postels \& Ruprecht

Order: Ectocarpales

Family: Punctariaceae

Distribution: Alaska to California

Bathymetry: mid intertidal

Description: Have a balloon-like shape and are covered with evenly distributed brown bumps. Tapered at the base.

Inconspicuous discoid holdfast. Epiphytic on

Neorhodomela and Odonthalia.

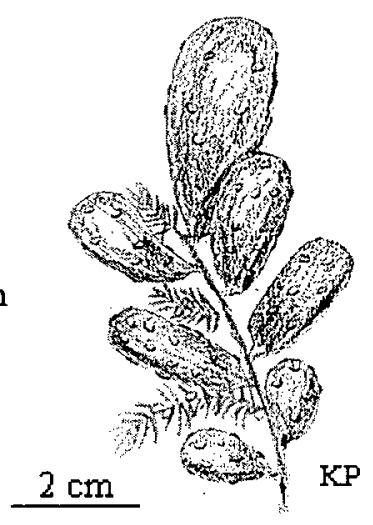

\section{RHODOPHYTA}

Bossiella orbigniana (Decaisne) Silva

Order: Corallinales

Family: Corallinaceae

Distribution: northern Southeast Alaska to Mexico;

Argentina

Bathymetry: extreme low intertidal and subtidal

Description: Combination of red pigments and calcium carbonate give this alga a pink color. Both the crustose base and erect branches it gives rise to are calcified. Branches are pinnately arranged off "wingnut" shaped segments greater than 2-3 $\mathrm{mm}$ across and about $1 \mathrm{~mm}$ long.

Clathromorphum reclinatum (Foslie) W.H.Adey Order: Corallinales

Family: Corallinaceae

Distribution: Alaska to southern California

Bathymetry: low intertidal

Description: Epiphytic, a combination of red pigments and calcium carbonate give this alga a pink color. Is slightly umbrella shaped with undulations. A close look reveals concentric circles on the disk.
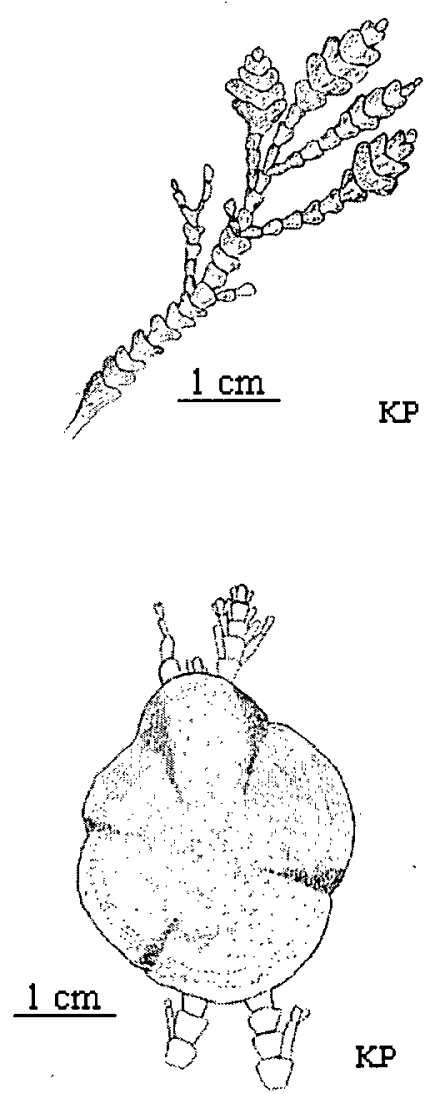
Corallina officinalis var. chilensis (Decaisne)

Kützing

Order: Corallinales

Family: Corallinaceae

Distribution: Prince William Sound, Alaska to

Mexico and Chile; Japan; Russia

Bathymetry: low intertidal and subtidal

Description: Combination of red pigments and

calcium carbonate give this alga a pink color. Both the crustose base and erect branches are calcified.

Branches are pinnately arranged at each of the 1.5 to $3 \mathrm{~mm}$ segments of the axis. Segments of the axis are flattened cylinders.

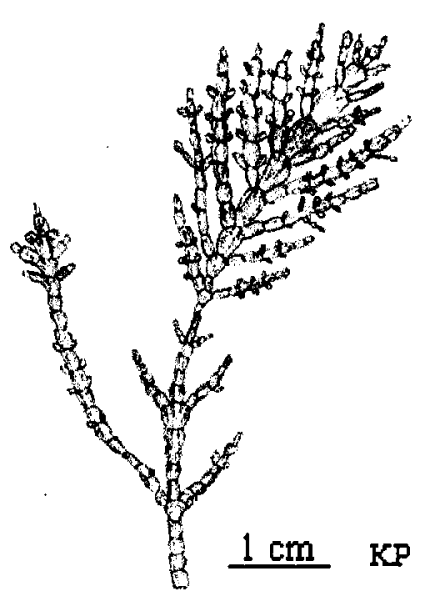

Halosaccion glandiforme (S.G. Gmelin) Ruprecht

Order: Palmariales

Family: Palmariaceae

Distribution: Bering Sea, Alaska to Point Conception, California; Kamchatka.

Bathymetry: mid intertidal

Description: Ranges in color from purple/red to yellow green depending on season. Elliptically shaped sacs are erect and filled with water. Attached at base by narrow discoid holdfast.

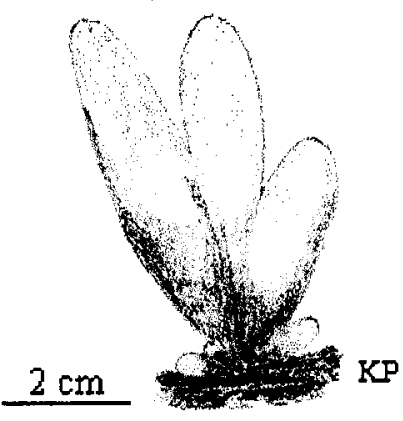

Hildenbrandia sp. Nardo

Order: Hildenbrandiales

Family: Hildenbrandiaceae

Distribution: Aleutian Islands, Alaska to Panama; Arctic; Chukchi sea; Galapagos Islands; Mediterranean, North Atlantic, Baltic.

Bathymetry: high to mid intertidal Description: Deep red color. A fleshy crustose alga closely ( $<1 \mathrm{~mm}$ ) adhered to rocks. Only sporophytic phase has been found, no

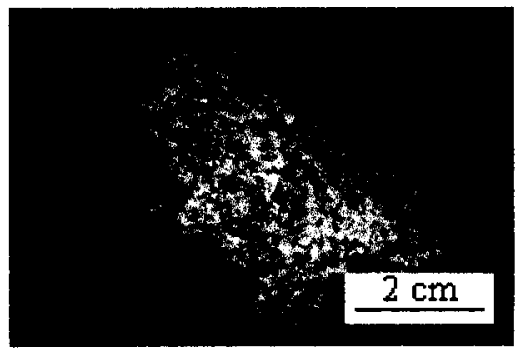
gametophytic phase known. Slow growing. 
Lithothamniom sp. Heydrich

Order: Corallinales

Family: Corallinaceae

Distribution: Alaska to California; Galapagos Islands, Ecuador and Japan.

Bathymetry: low intertidal on rocks and mid intertidal in tidal pools (intolerant to desiccation)

Description: Pink calcified crusts $(\sim 1 \mathrm{~mm})$ covering rocks and mollusks. Often with small branches

reaching up to $6 \mathrm{~mm}$ from the surface.

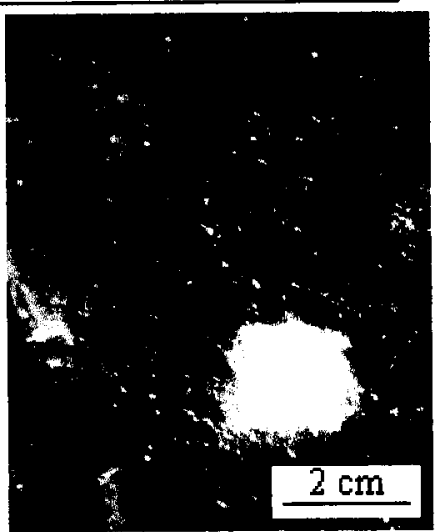

(O'Clair and Lindstrom, 2001)

Mastocarpus papillatus (C. Agardh) Kützing (Gametophyte)

Order: Gigartinales

Family: Phyllophoraceae

Distribution: Bering Sea, Alaska to Mexico; Japan and Russia

Bathymetry: mid upper intertidal

Description: A rich deep purple/red. On a short stipe, gametophytic blades annually grow out of a perennial crustose base. Blades are dichotomously

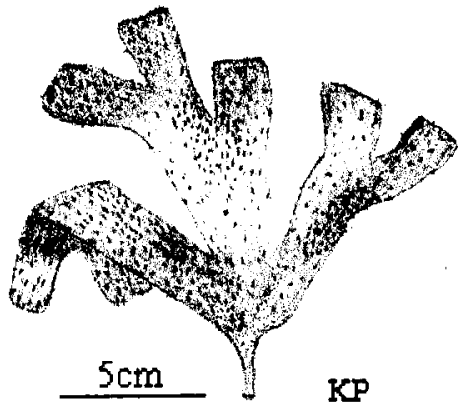
branched and are covered with gamete containing papillae, giving the surface a rough texture.

Mastocarpus papillatus (C. Agardh) Kützing (tetrasporophyte)

(formerly Petrocelis franciscana)

Order: Gigartinales

Family: Phyllophoraceae

Distribution: Bering Sea, Alaska to Mexico;

Japan and Russia

Bathymetry: mid upper intertidal

Description: Produced by gametophyte carpospores. Due to their heteromorphic nature, the tetrasporophytes were previously thought to be another species. Tetrasporophytes are also known as sea tar because of their black lobed crust. The crust is fleshy with irregular edges. Slow growing.

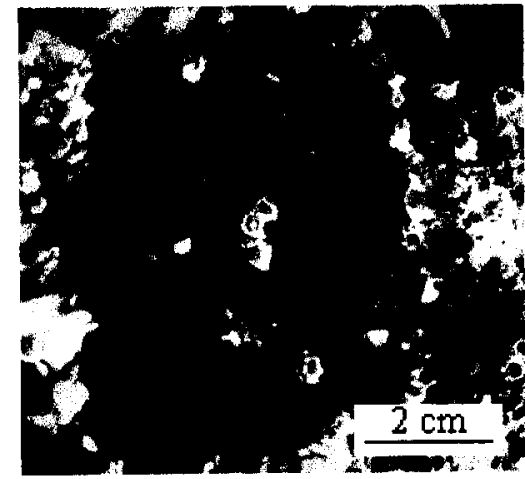

(O'Clair and Lindstrom, 2000) 
Mazzaella splendens (Setchell \& N.L. Gardner)

Fredericq

Order: Gigartinales

Family: Gigartinaceae

Distribution: Gulf of Alaska to Mexico

Bathymetry: low intertidal to upper subtidal

Description: Dark purple in color. A narrow holdfast leads to a short stipe and single blade. The ovate blade is thick and ruffled at the edges.

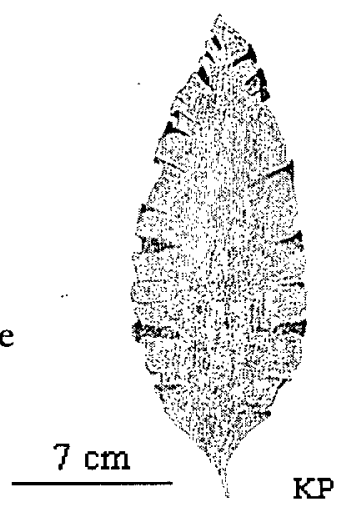

Microcladia borealis Ruprecht

Order: Ceramiales

Family: Ceramiaceae

Distribution: Aleutian Islands, Alaska to San Luis

Obispo County, California

Bathymetry: mid to low intertidal

Description: Dark red to olive in color. The holdfast is made up of a prostrate branch that is slightly

dissected. Alga is erect and branching in one plane, the blades are finely divided up to six times. Branches are arched and arise from the inside of the previous blade.

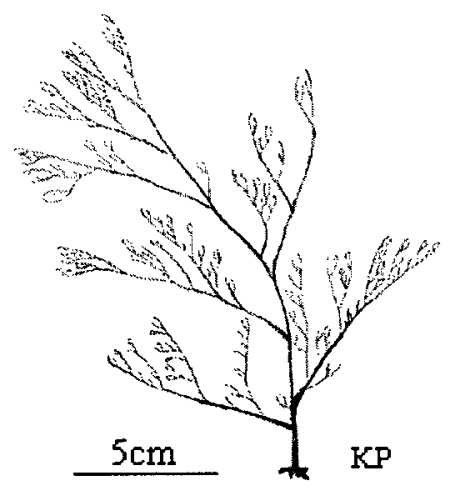

Odonthalia floccosa (Esper) Falkenberg

Order: Ceramiales

Family: Rhodmelaceae

Distribution: Bering Sea to Santa Barbara, California

Bathymetry: low intertidal

Description: Dark red to dark brown. Called the sea brush, this alga is highly branched. The main axis is erect and undulates.

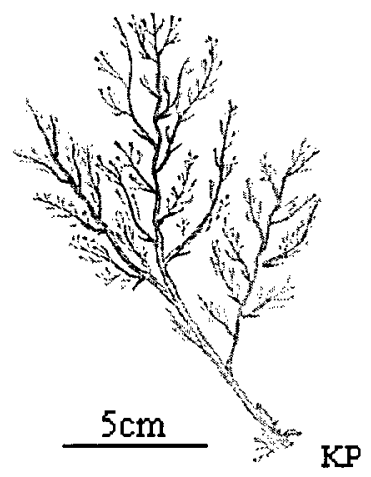


Porphyra perforata J. Agardh

Order: Bangiales

Family: Bangiaceae

Distribution: Aleutian Islands, Alaska to Mexico.

Okhotsk Sea, Russia.

Bathymetry: upper to low intertidal

Description: Is purple/red in color. Holdfast is

discoid and leads to a round ruffled blade.

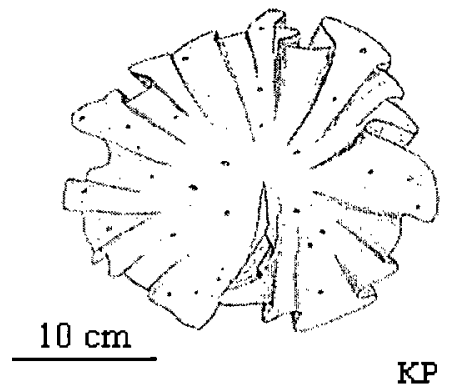

Prionitis lyallii Harvey

Order: Halymeniales

Family: Halymeniaceae

Distribution: Esquimalt, British Columbia to Baja,

California

Bathymetry: low intertidal to subtidal

Description: Brown to bright brick red in color.

Small holdfast leads to stipe $(1-7 \mathrm{~cm}$ long) that is

divided dichotomously several times. Blades are

lanceolate and 3-45 cm long. A diagnostic feature of

this alga is a distinct chlorine odor.

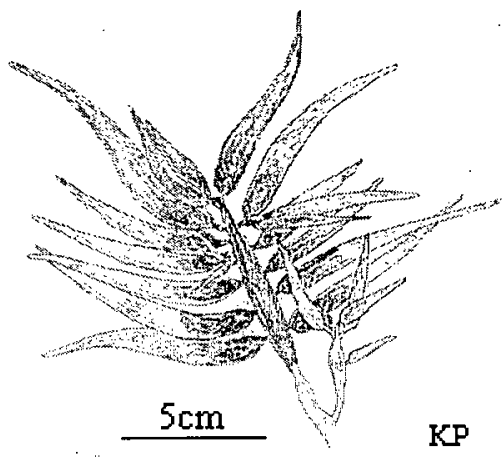

Smithora naiadum (Anderson) Hollenberg

Order: Compsogonales

Family: Erythrotrichiaceae

Distribution: Kodiak Island, Alaska to

Mexico

Bathymetry: low intertidal to upper subtidal

Description: Small red epiphyte of

Phyllospadix and Zostera grasses. Cushion

shaped holdfasts attach to the surface

(margins) of the grass. Blades are thin and

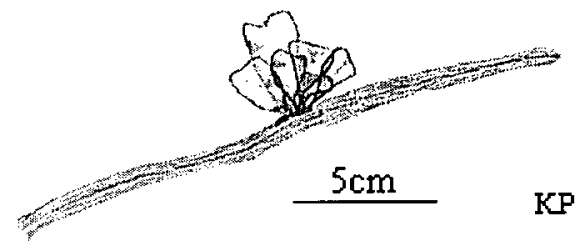

taper to a short stalk at the base. Sketch is of Smithora naiadum living

epiphytically on Phyllospadix scouleri. 


\section{CHLOROPHYTA}

Acrosiphonia coalita (Ruprecht) Scagel, Garbary, Golden \& Hawkes (new name Acrosiphonia mertensii) Order: Ulotrichales Family: Acrosiphoniaceae Distribution: Aleutian Islands, Alaska to central California

Bathymetry: mid to high intertidal Description: Gametophyte is a green filamentous alga up to $25 \mathrm{~cm}$ in length. The ends of the filaments have diagnostic hooks. The sporophyte

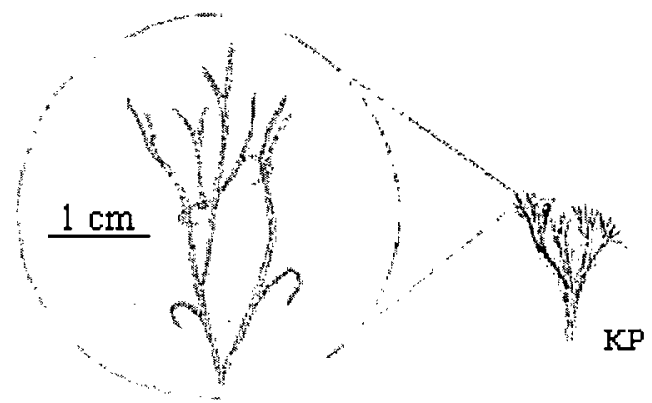
phase lives endophytically in

Mastocarpus papillatus which is included in this collection.

Codium fragile (Suringar) Hariot

Order: Codiales

Family: Codiaceae

Distribution: Mexico to Alaska, Japan and introduced to Atlantic

Bathymetry: mid intertidal to subtidal

Description: Dark blackish green in color. Tubular branches that are repeatedly dichotomously branched. Spongy and felt-like in texture.

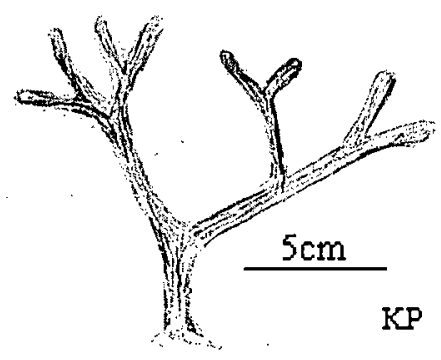

Ulva fenestrata Postels \& Ruprecht

Order: Ulotrichales

Family: Ulvaceae

Distribution: Alaska to Southern California

Bathymetry: mid to low intertidal

Description: Bright green, perforated, sheet-like blade arising from a holdfast.

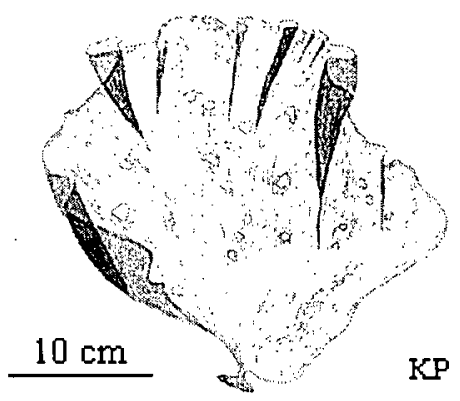


Ulva taeniata (Setchell ex Collins) Setchell \& N.L. Gardner Order: Ulotrichales

Family: Ulvaceae

Distribution: Southern British Columbia to Monterey County, California

Bathymetry: mid to low intertidal

Description: Blades are bright green. The holdfast is discoid and gives rise to one or several long blades (up to $1.5 \mathrm{~m}$ ). Edges of the blades are spirally twisted and slightly ruffled.

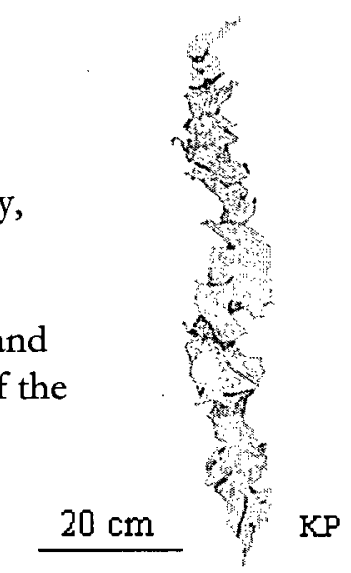

\section{ANTHOPHYTA}

Phyllospadix scouleri J. D. Hooker Family: Potamogetonaceae

Distribution: Sitka, Alaska to Mexico

Bathymetry: upper subtidal

Description: Although it appears to be a grass, Phyllospadix is not from the Poaceae. This surf grass is

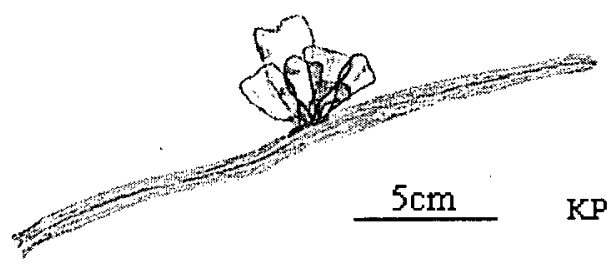
specially adapted to survive marine environments. Adaptations include: tolerance of high salt, flexible leaves and non-lignified xylem to withstand heavy surf, air spaces for floatation and complete lack of stomata. These plants are usually less than $1 \mathrm{~m}$ and leaves $4 \mathrm{~mm}$ wide. Well-developed roots and inconspicuous flowers which yield small heart-shaped fruit. Sketch is of Phyllospadix scouleri with Smithora naiadum epiphyte. 


\section{Methods and Materials}

\section{Collection}

Marine algae were collected at several locations including: French Beach, Vancouver Island $\left(48^{\circ} 23^{\prime} \mathrm{N}, 123^{\circ} 56^{\prime} \mathrm{W}\right)$, Acadia Beach, Vancouver (49 $17^{\prime} \mathrm{N}$, $\left.123^{\circ} 14^{\prime} \mathrm{W}\right)$ and Towers Beach, Vancouver $\left(49^{\circ} 16^{\prime} \mathrm{N}, 123^{\circ} 15^{\prime} \mathrm{W}\right)$. The primary collection was done at Whiffin Spit, Vancouver Island, $\left(48^{\circ} 22^{\prime} \mathrm{N}, 123^{\circ} 43^{\prime} \mathrm{W}\right)$ on July 28,1999 , during a -1.5 tide (Figure 2.3). At least three specimens were collected for each species. Samples were rinsed with fresh tap water to remove debris and epiphytes, air-dried at room temperature and stored at $4^{\circ} \mathrm{C}$. For each collection a voucher specimen was prepared and deposited at the University of British Columbia herbarium (UBC A84379-A84352). Vouchers were identified to species using Scagel (1967); Hustedt, (1985) and O'Clair and Lindstrom (2000) and classification was confirmed with the help of Drs. Rob DeWreede, Sandra Lindstrom and Max Taylor (Botany Department, University of British Columbia).

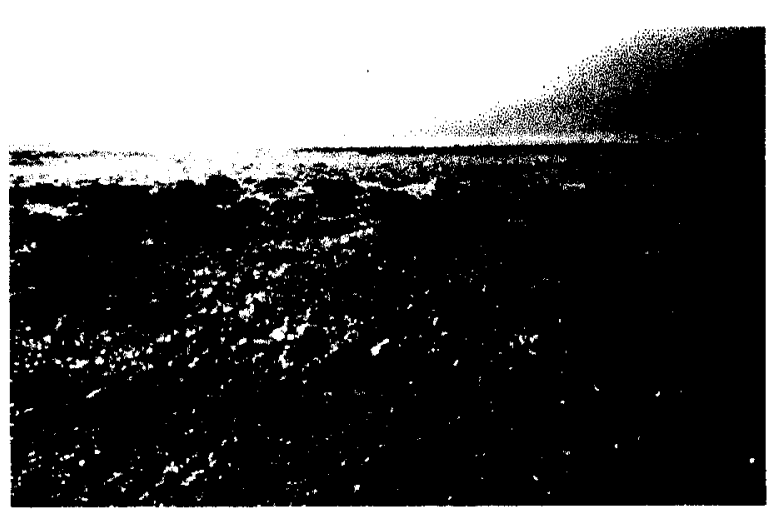

a

Figure 2.3. Collection site Whiffin Spit, Vancouver Island. a) low to mid intertidal b) upper intertidal.

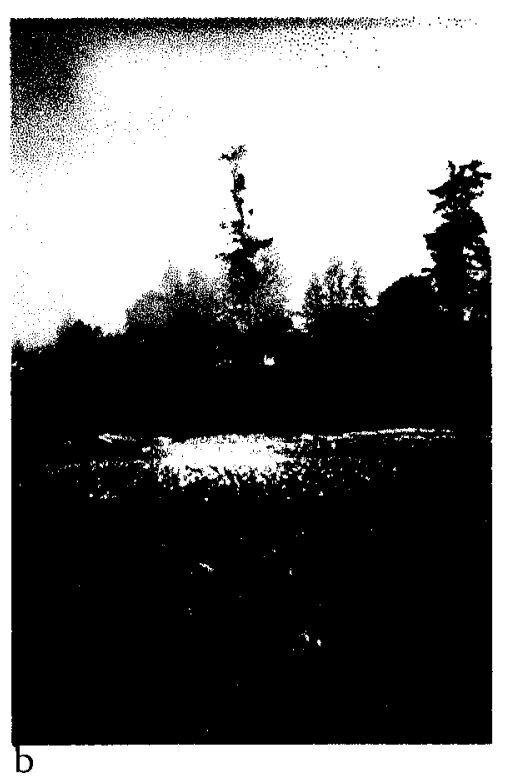


All of the taxa screened in this study, except the sea grass Phyllospadix scouleri, were algae. Since species composition changes significantly throughout the littoral zone, collections were made from low to high intertidal. Causes for these changes in community diversity relate to species' adaptation to length of exposure between tides and aquatic light conditions (Levring, 1979). In choosing the collection site, algal diversity was an important consideration. Whiffin Spit on southwestern Vancouver Island has moderate wave exposure and salinity as well as an intertidal zone of several hundred metres. The moderate growing conditions combined with a large habitat allow for wide range of species to inhabit Whiffin Spit, thus contributing to biodiversity (R.E. DeWreede personal communication) which in turn is often associated with chemical diversity (Carté, 1996).

\section{SOURCE OF VIRUS}

A severe strain of PVX from collections at the Pacific Agri-Food Research Centre (Summerland, B.C., Canada) was purified and stored as previously described (French \& Towers, 1992).

\section{EXTRACTION}

Approximately $2 \mathrm{~g}$ of each algal specimen was ground in liquid nitrogen using a mortar and pestle and extracted three times with $30 \mathrm{ml}$ of $100 \%$ methanol (ACS grade- Fisher). Grinding with liquid nitrogen was the best way to overcome the tough, elastic nature of the algae. Resulting supernatants were vacuum filtered (Whatman No.1 filter paper) and dried in vacuo at $30{ }^{\circ} \mathrm{C}$ using a Yamato model RE 47 rotavaporator (Japan). 


\section{BIOASSAYS}

\section{Local lesion assay}

Extracts were tested for antiviral activity against PVX using local lesion assays (LLA) in C. quinoa (French et al., 1991). Screening of each algal extract for anti-PVX activity was done using three plants (5-6 weeks of age), each with 4 test leaves. Control and treatment replicates were applied to the same leaf by dividing the 4 test leaves per plant arbitrarily into control and treatment halves. To compare the effect of one sample over another on the infectivity of the virus, it is recommended that at least six to eight leaf halves be tested. In this study all extracts were tested on 12 - 24 leaf halves (Matthews, 1991). Leaves were dusted with carborundum, a fine abrasive that facilitates virus transmission by producing small openings in the epidermal layer. The control side of each leaf received

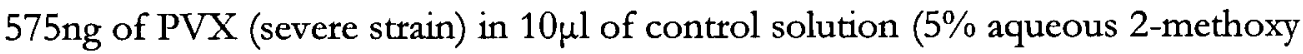
ethanol-Fisher). Each treatment side also received 575ng of PVX suspended in $10 \mu l$ of control solution, plus the respective algal extract at a final concentration of $10 \mu \mathrm{g} / \mu \mathrm{l}$. Both the control and treatment virus preparations were incubated $\left(25^{\circ} \mathrm{C}\right.$ water bath/shaker) for 30 minutes before application to leaves with a gloved finger. Infected plants were placed in a growth chamber $\left(20^{\circ} \mathrm{C}\right.$, cool white light, $16 \mathrm{~h}$ light:8h dark) for 5 to 6 days while lesions developed. The effect of the algal extract on viral infectivity was determined by comparing the relative number of lesions on both sides of the test leaves. All extractions and assays were completed in duplicate using the above methods.

The activity of selected extracts was determined by testing four crude extracts of moderate to high antiviral activity (E. menziesii, A. nana, U.taeniata, and F.gardneri) in a dilution series $(10 \mu \mathrm{g} / \mu \mathrm{l}, 1 \mu \mathrm{g} / \mu \mathrm{l}, 0.1 \mu \mathrm{g} / \mu \mathrm{l}$ and $0.01 \mu \mathrm{g} / \mu \mathrm{l})$ using the above method. These four extracts plus Fragilaria oceanica were further tested $(10 \mu \mathrm{g} / \mu \mathrm{l})$ four months after their extraction to evaluate the stability of their active constituents. To complement the LLAs with PVX, assays were repeated with tobacco mosaic virus (TMV) and potato virus Y (PVY). Difficulty 
with PVY infectivity resulted in assays being repeated with virus from several sources and from different preparations. These included testing 14 PVY isolates (Table 2.3) from Pacific Agri-Food Research Centre frozen storage in hosts: $C$. quinoa, C. quinoa cv. 'sensitive' and/or Nicotiana alata cv. 'lime green'.

Table 2.3: Potato virus $Y$ isolates inoculated into all or one of the following hosts, C. quinoa, C. quinoa cv. 'sensitive', Nicotiana alata Cv. 'lime green'.

\section{Potato virus $\mathrm{Y}$ isolates from PARC}

PVY flavda plate 72 5C O+C/N+C PVY $37 \mathrm{~B}(14 / 5 / 93)$

PVY TC isolate $\quad$ PVY $37 \mathrm{C}(18 / 5 / 93)$

PVY NE $391 \quad$ PVY $37 \mathrm{D}(8 / 8 / 93)$

PVY $^{\circ} 1056 \quad P V Y(24 / 5 / 83)$

PVY ME 1588

PVY F batch I $(4 / 1 / 74)$

PVY flavda plate $125 \mathrm{C} \mathrm{O}+\mathrm{C} / \mathrm{N}+\mathrm{C} \quad$ PVY F batch II $(4 / 1 / 74)$

PVY 37 A $(24 / 3 / 93)$ $\mathrm{PVY}^{0-3}$

\section{Application of Fucus gardneri extract to PVX infected potato tissue culture}

Crude and semi-pure fractions of $F$. gardneri were assayed for antiviral activity against PVX using systemically infected cultures of $S$. tuberosum cv. 'True Blue'. Sterile cultures of $S$. tuberosum were grown on solid medium $(30 \mathrm{~g}$ sucrose, 4.4g BC potato media 82 (PM) (Carolina Biological Supply), $5.6 \mathrm{~g}$ agar/litre, $\mathrm{pH} 5.7$ ) and leaves were mechanically inoculated with $10 \mu \mathrm{l}$ of PVX $(1.15 \mathrm{mg} / \mathrm{ml})$ in $10 \mathrm{mM}$ sodium phosphate buffer, $\mathrm{pH}$ 7.2. After 21 days, PVX infection was confirmed by ELISA. Stems were severed leaving five nodes. After removing the leaves, ten shoots were transferred aseptically to liquid culture (PM without agar) in two Sigma culture boxes. Liquid media were modified by the addition of algal extracts to produce six treatments: crude $F$. gardneri $(10 \mu \mathrm{g} / \mu \mathrm{l}$, $1 \mu \mathrm{g} / \mu \mathrm{l} \& 0.1 \mu \mathrm{g} / \mu \mathrm{l})$, semi-pure $F$. gardneri $1 \mu \mathrm{g} / \mu \mathrm{l}$ (butanol fraction), positive control (Ribavirin $0.02 \mu \mathrm{g} / \mu \mathrm{l}$ ) and negative control (no treatment). Plant cultures were grown in a Sanyo growth chamber $\left(16 \mathrm{~h} \mathrm{light:} 8 \mathrm{~h}\right.$ dark $/ 23^{\circ} \mathrm{C}$ ). At 30 days, 
shoot tips were excised from the developed lateral shoots and transferred to solid media containing either treatments as before or fresh standard media without additions. At sixty days, $0.05-0.15 \mathrm{~g}$ of leaves from each treatment were collected and ground (Erich Pollänhne, model R30DT71K4/2 with beveled rollers manufacturer, Germany) with extraction buffer [8.0g NaCl, $0.2 \mathrm{~g} \mathrm{KH}_{2} \mathrm{PO}_{4}, 1.15 \mathrm{~g}$ $\mathrm{Na}_{2} \mathrm{HPO}_{4}, 0.2 \mathrm{~g} \mathrm{KCl}, 2 \mathrm{~g}$ polyvinyl-pyrrolidone (M.W. 44,000), 0.5ml Tween 20/litre, $\mathrm{pH} 7.4]$ to a final concentration of $0.15 \mathrm{~g} / \mathrm{ml}$. Plant homogenates were assayed for PVX using ELISA (Clark et al., 1976).

In preparation for ELISA, 96 well polystyrene trays were coated with PVX-specific antibodies dissolved in $100 \mu \mathrm{l}$ of coating buffer $\left[1.82 \mathrm{~g} \mathrm{Na}_{2} \mathrm{CO}_{3} \cdot \mathrm{H}_{2} \mathrm{O}\right.$, $2.93 \mathrm{~g} \mathrm{NaHCO}_{3} /$ litre with $2 \mu \mathrm{l}$ PVX-specific antibody (final antibody concentration 1/5000 stock - Phytodiagnostics, North Saanich, B.C., Canada) per $10 \mathrm{ml}$ buffer] per well. Trays were incubated at $37^{\circ} \mathrm{C}$ for 4 hours, washed three times using 100-200 $\mu$ PBS-T buffer $\left(8.0 \mathrm{~g} \mathrm{NaCl}, 0.2 \mathrm{~g} \mathrm{KH}_{2} \mathrm{PO}_{4}, 1.15 \mathrm{~g} \mathrm{Na}_{2} \mathrm{HPO}_{4}\right.$, $0.2 \mathrm{~g} \mathrm{KCl}, 0.5 \mathrm{ml}$ Tween 20/litre, $\mathrm{pH}$ 7.4) per well and blotted dry. Sample homogenates $\left(100 \mu \mathrm{l} /\right.$ well) and standards in duplicate wells were incubated at $4^{\circ} \mathrm{C}$

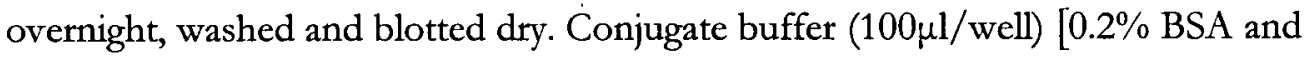
$10 \mu$ l conjugate antibody (final antibody concentration 1/1000 stock solution Phytodiagnostics, North Saanich, B.C., Canada) per $10 \mathrm{ml}$ of PBS-T buffer] was added and the trays were incubated for 2 hours at $37^{\circ} \mathrm{C}$. To ensure all unbound conjugate antibody was removed, wells were washed 4 times with PBS-T buffer and blotted dry. Next added $100 \mu \mathrm{l}$ per well of enzyme substrate $[15 \mathrm{mg} p$ nitrophenyl phosphate (Sigma) to $30 \mathrm{ml}$ substrate buffer (diethanolamine $97 \mathrm{ml}$ per litre $\mathrm{pH}$ 9.8)]. The resulting color reaction is proportionate to the virus titer of each well. Absorbance was monitored $(405 \mathrm{~nm})$ with an ELISA plate reader (Titertek Multiskan, Flow Laboratories International, Switzerland) at 20,40 and 60 minutes. 


\section{Results}

\section{LOCAL LESION ASSAYS}

Initial screening of algal extracts showed antiviral activity with two (Ralfsia sp. and Codium fragile) of the five extracts inhibiting PVX infectivity by more than $90 \%$. Of the 31 species tested, extracts of algae collected had effects ranging from slight stimulation (19\%) to complete inhibition of PVX infection (Table 2.4). Six species (F. gardneri, A. nana, Ralfsia sp., E. menziesii, $C$. fragile and $F r$. oceanica.) had strong (>80\%) antiviral effects. When applied to the leaves of $C$. quinoa none of the extracts appeared to cause obvious phytotoxicity such as necrosis, yellowing or reduced growth. When tested against TMV in $C$. quinoa, only the extract of $F$. gardneri resulted in viral inhibition greater than $80 \%$ (Table 2.5). Unfortunately due to problems with greenhouse pests, not all algal extracts were successfully assayed for activity against TMV. Problems with stability of PVY infectivity following virus isolation resulted in no data being collected for this virus. 
Table 2.4: Local lesion antiviral assay from algae screening. Inhibition of potato virus $\mathrm{X}$ infectivity by extracts of marine organisms at $10 \mu \mathrm{g} / \mu \mathrm{l}$ using a local lesion assay on the leaves of C. quinoa.

\begin{tabular}{lr}
\multicolumn{1}{c}{ Species } & \% Inhibition of \\
& PVX infectivity \\
\hline Heterokontophyta & \\
Fucus gardneri & $100.0 \pm 0$ \\
Alaria nana & $98.9 \pm 0.4$ \\
Ralfsia sp. & $97.2 \pm 0.7$ \\
Fragilaria oceanica & $83.5 \pm 10.6$ \\
Egregia menziesii & $80.3 \pm 2.5$ \\
Colpomenia peregrina & $50.0 \pm 17.1$ \\
Hedophyllum sessile & $44.6 \pm 10.6$ \\
Cymathere triplicata & $39.8 \pm 17.4$ \\
Laminaria saccharina & $38.8 \pm 18.6$ \\
Nereocystis luetkeana & $31.3 \pm 18.4$ \\
Costaria costata & $27.5 \pm 12.7$ \\
Soranthera ulvoidea & $26.19 \pm 24.5$ \\
\hline Chlorophyta & \\
Codium fragile* & $92.8 \pm 3.4$ \\
Ulva taeniata & $77.1 \pm 25.6$ \\
Ulva fenestrata & $73.8 \pm 25.2$ \\
Acrosiphonia coalita & $44.9 \pm 10.7$ \\
\hline Rhodophyta & \\
Porphyra perforata & $45.7 \pm 9.8$ \\
Smithora naiadum & $44.7 \pm 11.6$ \\
Mazzaella splendens & $41.2 \pm 14.6$ \\
Clathromorphum reclinatum & $37.3 \pm 13.2$ \\
Bossiella orbigniana* & $36.4 \pm 13.6$ \\
Prionitis lyallii & $29.7 \pm 20.8$ \\
Hildenbrandia sp. & $24.4 \pm 26.1$ \\
Microcladia borealis & $23.2 \pm 25.0$ \\
Corallina officinalis & $19.5 \pm 3.2$ \\
Mastocarpus papillatus (gametophyte) & $18.8 \pm 21.9$ \\
Odonthalia floccosa & $7.13 \pm 15.4$ \\
Mastocarpus papillatus (tetrasporophyte) & $7.0 \pm 22.5$ \\
Lithothamniom sp. & $-0.9 \pm 28.7$ \\
Halosaccion glandiforme & $-19.7 \pm 29.4$ \\
\hline Phyllospadix scouleri & \\
experiments (standard error represented with \pm t), each experiment consisting of \\
test leaves. Positive values refer to viral inhibition. Negative values refer to viral stimulation. \\
\hline Angiosperm
\end{tabular}


Table 2.5: Inhibition of TMV- $\mu 1$ by select algal extracts. Antiviral effect determined using local lesion assays on $C$. quinoa.

\begin{tabular}{lc}
\hline Extract & $\begin{array}{c}\text { \% Inhibition of } \\
\text { TMV }-\mu 1\end{array}$ \\
\hline Fucus gardneri & $86.2 \pm 4.9$ \\
Ralfsia sp. & $59.6 \pm 7.3$ \\
Fragilaria oceanica & $46.8 \pm 11.4$ \\
Microcladia borealis & $43.4 \pm 27.9$ \\
Ulva fenestrata & $41.1 \pm 8.0$ \\
Ulva taeniata & $29.2 \pm 18.7$ \\
Codium fragile & $24.5 \pm 17.5$ \\
Hedophyllum sessile & $20.5 \pm 36.7$ \\
Porphyra perforata & $18.8 \pm 21.3$ \\
Alaria nana & $-4.1 \pm 2.9$ \\
Mazzaella splendens & $-5.2 \pm 32.8$ \\
Costaria costata & $-34.6 \pm 19.2$ \\
\hline
\end{tabular}

Results are means \pm standard error of two separate experiments, each experiment consisting of 3 plants with 4 test leaves. Positive values refer to viral inhibition. Negative values refer to viral stimulation.

Results from the dilution series $(10 \mu \mathrm{g} / \mu \mathrm{l}-0.001 \mu \mathrm{g} / \mu \mathrm{l})$ showed the effect of concentration on the bioactivity of select extracts (Table 2.6). Full strength treatments $(10 \mu \mathrm{g} / \mu \mathrm{l})$ were consistent with results found in previous screening. At a concentration of $1 \mu \mathrm{g} / \mu \mathrm{l}, F$. gardneri was the only extract to inhibit PVX infection by more than $80 \%$. As algal extract concentration was reduced many treatments stimulated virus infectivity. The five extracts assayed four months after their extraction resulted in quite different apparent stabilities of bioactive molecules (Table 2.7). Extracts from both Fr. oceanica and U. taeniata showed a dramatic loss of bioactivity, whereas the bioactivity of the other three extracts remained essentially unchanged. 
Table 2.6: Percent PVX inhibition tested, using a local lesion assay on C. quinoa, over a logarithmic dilution series of four crude extracts.

\begin{tabular}{l|lllll}
\hline \multicolumn{7}{c}{ Concentration of dilution series } \\
\hline Species & $\mathbf{1 0} \boldsymbol{\mu g} / \boldsymbol{\mu l}$ & $\mathbf{1} \boldsymbol{\mu g} / \boldsymbol{\mu l}$ & $\mathbf{0 . 1} \boldsymbol{\mu g} / \boldsymbol{\mu l}$ & $\mathbf{0 . 0 1} \boldsymbol{\mu g} / \boldsymbol{\mu l}$ & $\mathbf{0 . 0 0 1} \boldsymbol{\mu g} / \boldsymbol{\mu l}$ \\
Fucus gardneri & $99.5 \pm 0.4$ & $93.6 \pm 2.5$ & $-2.1 \pm 10.3$ & $-59.5 \pm 21.2$ & $-16.8 \pm 13.8$ \\
Alaria nana & $99.4 \pm 0.3$ & $24 \pm 21.7$ & $-4.1 \pm 55.9$ & $5.6 \pm 7.4$ & $\mathrm{ND}$ \\
Egregia menziesii & $85.9 \pm 1.1$ & $-29 \pm 41.9$ & $-54.2 \pm 20$ & $-12 \pm 27.8$ & $\mathrm{ND}$ \\
Ulva taeniata & $73.5 \pm 7.9$ & $16.7 \pm 14$ & $-93 \pm 27.6$ & $-52.1 \pm 55.4$ & $\mathbf{1 8 . 7 \pm 1 3 . 4}$ \\
\hline
\end{tabular}

Results are means \pm standard error of two separate experiments, each experiment consisting of 3 plants with 4 test leaves. Positive values refer to viral inhibition. Negative values refer to viral stimulation. ND: not determined.

Table 2.7: Anti-PVX activity of select algal extracts 4 months after extraction.

\begin{tabular}{lcc}
\hline \multicolumn{1}{c}{ Species } & $\begin{array}{c}\text { \% Inhibition of } \\
\text { PVX infectivity }\end{array}$ & $\begin{array}{l}\text { Original } \\
\text { Bioactivity }\end{array}$ \\
\hline Alaria nana & $98.9 \pm 0.7$ & $98.9 \pm 0.4$ \\
Egregia menziesii & $81.8 \pm 8.9$ & $80.3 \pm 2.5$ \\
Fragilaria oceanica & $36.4 \pm 12.8$ & $83.5 \pm 7.3$ \\
Fucus gardneri & $100 \pm 0$ & $100 \pm 0$ \\
Ulva taeniata & $-22.8 \pm 4.9$ & $77.1 \pm 25.6$ \\
\hline
\end{tabular}

Results are means \pm standard error of two separate experiments, each experiment consisting of 3 plants with 4 test leaves. Positive values refer to viral inhibition. Negative values refer to viral stimulation.

\section{APPLication of F. gardneri EXTRACT TO PVX INFECTED POTATO TISSUE CULTURE}

After 30 and 60 days of chemotherapy, algal treatments showed little or no reduction in PVX concentration, whereas ribavirin showed a considerable antiviral effect (Table 2.8). Inclusion of 30 day and 60 day chemotherapy exposures was designed to verify virus eradication rather than virus suppression. Virus suppression would result in 30 day treatments showing increased virus titer after removal from chemotherapy. In treatments that were antiviral this was not the case, all 30 and 60 day treatments were comparable. Ribavirin treatment $(\mathbf{E})$ resulted in general stunting as found previously (Wambugu et al., 1985) (Figure 2.4). The highest concentration of crude $F$. gardneri $(\mathbf{C})$ was severely phytotoxic 
leaving stems etiolated, leaves reduced in number and size and limited root development.

Table 2.8: Effects of crude and semi-pure fractions of Fucus gardneri extract were tested against PVX-infected $S$. tuberosum culture.

\begin{tabular}{lcc}
\hline \multicolumn{1}{c}{ Treatment } & \multicolumn{2}{c}{ Absorbance } \\
& 30 days* & 60 days* \\
\hline Crude Fucus extract @ $10 \mu \mathrm{g} / \mu \mathrm{l}(\mathbf{C})$ & $0.556 \pm 0.024$ & ND \\
Crude Fucus extract @ $1 \mu \mathrm{g} / \mu \mathrm{l}(\mathbf{B})$ & $0557 \pm 0.012$ & $0.455 \pm 0.020$ \\
Crude Fucus extract @ $0.1 \mu \mathrm{g} / \mu \mathrm{l}(\mathbf{A})$ & $0.553 \pm 0.012$ & $0.442 \pm 0.045$ \\
Semi-pure Fucus extract @ $1 \mu \mathrm{g} / \mu \mathrm{l}(\mathbf{D})$ & $0.573 \pm 0.009$ & $0.496 \pm 0.009$ \\
Negative control (no treatment) & $0.382 \pm 0.077$ & $0.510 \pm 0.008$ \\
Positive control (Ribavirin @ $20 \mu \mathrm{g} / \mathrm{ml})(\mathbf{E})$ & $0.116 \pm 0.104$ & $0.009 \pm 0.001$ \\
\hline
\end{tabular}

${ }^{a} A$ bsorbance at $405 \mathrm{~nm}$ measures color change in ELISA assay, and consequently is proportional to PVX concentration in the sample.

Two treatments: 30 days chemotherapy followed by 30 days on unmodified media, 60 days chemotherapy. ND: not determined due to toxicity. Each treatment measurement is the summary of 5-10 replicates.

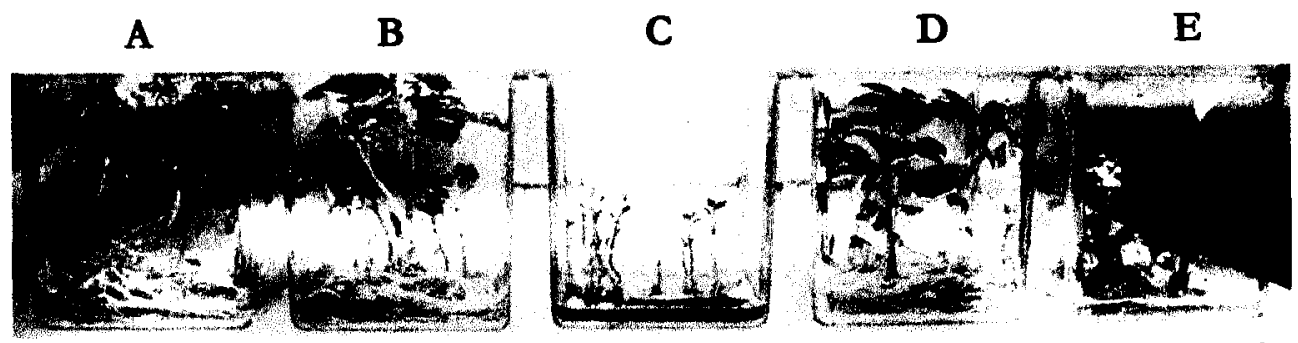

Figure 2.4: Potato tissue culture after 30 days of chemotherapy. Liquid media of each treatment supplemented (A) crude Fucus gardneri $0.1 \mathrm{mg} / \mathrm{ml}$ (B) crude Fucus gardneri $1 \mathrm{mg} / \mathrm{ml}$ (C) crude Fucus gardneri $10 \mathrm{mg} / \mathrm{ml}$ (D) Fucus gardneri butanol fraction $1 \mathrm{mg} / \mathrm{ml}$ (E) Ribavirin $20 \mu \mathrm{g} / \mathrm{ml}$. Reduced growth due to toxicity of treatments in $\mathbf{E}$ and particularly $\mathbf{C}$. 


\section{Discussion}

\section{LOCAL LESION ASSAY}

Marine algae have only recently been found to contain compounds inhibitory to plant viruses (Padmakumar and Ayyakkannu, 1997; Galal et al., 1999). This current study adds to the list of taxa known to contain such compounds and is the first to screen for activity against PVX. Local lesion assays detected inhibition of infectivity suggesting an antiviral effect occurring either in vitro during incubation or in vivo during the onset of infection. Of 31 species screened, six contained strong bioactivity $(>80 \%)$ that dramatically reduced the number of local lesions induced on C. quinoa (Table 2.4). Finding that $20 \%$ of extracts strongly inhibit viral infectivity adds credence to previous claims that marine extracts have great potential therapeutic value (Munro et al., 1987; Carté, 1996). Extracts of $H$. glandiforme (19\% stimulation) and $F$. gardneri $(100 \%$ inhibition) represent the extremes of antiviral effect found in the screening. To delineate the potency of some of the most active extracts, $F$. gardneri, $A$. nana, E. menziesii and $U$. taeniata were assayed over a concentration gradient (Table 2.6). The antiviral performance of crude $F$. gardneri extract at $1 \mu \mathrm{g} / \mu \mathrm{l}$ emphasizes the potential of this extract for phytochemical analysis. Below a concentration of $1 \mu \mathrm{g} / \mu \mathrm{l}$, several treatments resulted in stimulation of viral infection. This effect may be an artifact of experimental design. However, it possibly illustrates concentration dependent interactions between viral antagonizers and stimulators (i.e.: RNase inhibitors) both present in the algae.

These four extracts plus Fr. oceanica were tested 4 months after extraction to evaluate the stability of the bioactive compounds. The extracts of all three brown algae (A. nana, E. menziesii, $F$. gardneri) remained unchanged, whereas both $U$. taeniata (Chlorophyta) and Fr. oceanica (diatom) lost significant bioactivity (Table 2.7). The finding that bioactivity of $U$. taeniata is 
not tolerant of storage concurs with previous observations that bioactive compounds from Chlorophyta are notoriously unstable (Paul and Fenical, 1987). Despite diatoms being the largest microalgal population in marine ecosystems very little study of their metabolites as anti-infectives has been done (Shimizu, 1993), therefore no precedence on the chemical stability of their secondary metabolites was found.

The partial screening of algal extracts against tobacco mosaic virus found that only F. gardneri strongly inhibited infectivity of this virus (Table 2.5). Tobamoviruses and Potexviruses are not serologically related, differences between the surface moieties of these to viruses perhaps have led to this difference in efficacy of algal extracts (Brunt et al., 1996). However, it is unusual that $F$. gardneri exerted an effect while the other active brown alga; $A$. nana did not, perhaps suggesting that the modes of action of these two brown algae are different. The assays were completed 2 months after the extraction of the algae, therefore compound degradation, especially in the case of extracts from the Chlorophyta and diatoms, may have contributed to the low overall effect. However, the same extract of $A$. nana, used two months later in the four-month assay, remained strongly antiviral against PVX (Table 2.7).

Several algal taxa identified as inhibitory against PVX also inhibited human viruses. For example, extracts of Alaria nana, Codium fragile and Egregia menziesii have been found to be antiviral against herpes simplex-1 (HSV-1) and/or Sindbis (Kim et al., 1997; Hudson et al., 1999a,b) and extracts of Fucus vesiculosus against human immunodeficiency virus (HIV) (Beress et al., 1993). It is tempting to speculate that compounds with broad antiviral effect may occur in these taxa. However, differences in the nature of plant and animal viruses (i.e.: often membrane envelope) suggest that the common antiviral effect is the result of different algal constituents or modes of action.

As mentioned earlier, marine algae are not a monophyletic group, some belong to the Kingdom Plantae and others to the Kingdom Chromista. The algal 
sources of the most antiviral extracts in our study suggest a chemotaxonomic relationship based on this phylogenetic division. As Table 2.4 illustrates, 5 of the 6 most active algal extracts $(F$. gardneri, $A$. nana, Ralfsia sp., E. menziesii and Fr. oceanica) are from Heterokont taxa belonging to the Kingdom Chromista (Cavalier-Smith, 1998). The high representation of Heterokont species in the most antiviral extracts raises the possibility of inhibition being the result of common or related compounds. Members of the Heterokontophyta (brown algae) were identified in the early 1980's as a promising source of antiviral compounds (Rinehart, et al., 1981); however, this trend is not reflected in studies using plant viruses (Galal et al., 1999; Padmakumar and Ayyakkannu, 1997) or recent antiviral research on human viruses (reviewed in Schaeffer and Krylov, 2000; Hudson et al., 1999a,b). Nonetheless, findings in this study suggest that this group of algae contains potent antiviral agents, and that further screening of extracts from Heterokont taxa could prove to be rewarding.

A high degree of variation was a considerable factor in a number of extracts, this variation appeared to originate from three possible sources: experimental, the local lesion host and algal substances. Sources of variation were reduced in the experimental design by combining control and test treatments on the same leaf and by standardizing plant age, nutrition, moisture, and light intensity between replicates. Some factors however cannot be regulated, one being the sensitivity of the assay. The local lesion assay relies on the hypersensitive response of $C$. quinoa which requires the presence of many viable virus particles for lesion development (Zaitlin and Palukaitis, 2000). Consequently the number of lesions on a leaf is dependent not only on the viability of the virus, but also on virus distribution over the leaf. surface and therefore is only an approximation of viable virus.

However for a large part, variation observed between replicates appears to be primarily an artifact of the host response. Although the local lesion assay 
serves the purposes of this study well, there is an inherent problem with variation (Matthews, 1991). This becomes apparent when the data are arranged in order of increasing viral inhibition; the standard error substantially diminishes as the potency of antiviral effect increases (Table 2.4). Kleczkowski (1949) suggested that such variation observed in local lesion assays is a function of an increase in the mean number of lesions; however in this study there was no such correlation. What may be contributing to this variation, which increases proportionately with percent infectivity, is a manifestation of the following. The hypersensitive response is induced by very specific host/pathogen interactions. However, the defense response (i.e.: lesion development or alternative event) is non-specific and involves metabolic changes specific to each host (Fritig et al., 1990). Consequently, as the number of "infection events" (i.e.: lesions) increase relative to the control, it is possible that the non-specific nature (i.e.: variability) of the defense response becomes more apparent.

A further possible source of variation may come from the algal extracts themselves. As with any study involving natural populations: environmental, community, seasonal and individual factors can introduce variation between individual organisms (Duffy and Hay, 1990: Tuomi et al., 1989). It is possible that compositional differences between specimens contributed to variation by influencing the concentration and/or presence of biologically active compounds. As Neushul (1990) described with reference to the Rhodophyta, variation is an inherent difficulty in working with algae. For example, abundance of the polysaccharide fucoidan within members of the brown algae varies dramatically with both the depth and season a specimen is collected (Percival, 1970). Furthermore, resident microorganisms may actually be the sources of active metabolites (He et al., 2001; Shimizu, 1993). Therefore the presence or absence of resident bioactive microorganisms, epiphytes or endophytes associated with the algae could add to variation. An interesting observation related to this has to do with the high degree of variation found with specimens of Mastocarpus 
papillatus tetrasporophyte (Table 2.4). Microscopic evaluation of this species found highly variable amounts of unicellular Acrosiphonia sp. endophytes within its tissue. Perhaps, the high variability observed with the antiviral effect of extracts from Mastocarpus papillatus tetrasporophyte reflects differences in the abundance of Acrosiphonian or collaborative metabolites.

\section{APPlication of Fucus gardneri EXTRACT TO PVX INFECTED POTATO TISSUE CULTURE}

Based on antiviral performance, extracts of $F$. gardneri appeared to be the most promising for chemical analysis; thus, this extract was further assayed for efficacy against systemic PVX infection. This bioassay, in contrast to LLAs, evaluated extracts for antiviral effect against established infections rather than the onset of infection. Treatments in this assay included three concentrations of crude extract and a semi-pure fraction, all verified as active in local lesion assays. However, after both 30 and 60 days of algal chemotherapy in tissue culture, all fractions failed to show antiviral effect (Table 2.8). This may indicate that active compounds are not effective against systemic infection; however, it could also simply reflect a problem with delivery of the active compounds to infected leaves. Previous work done with animal viruses has implicated biopolymers such as polyphenols, peptides and polysaccharides in the antiviral activity of algae (Schaeffer and Krylov, 2000). Is it possible that the size of the bioactive molecule(s) in F. gardneri caused problems with uptake by the roots? Compounds such as polysaccharides and polyphenols are capable of passing into either animal or plant root cells (Logeart et al., 1997; A.D.M. Glass, personal communication). However, it is possible that compounds responsible for the antiviral effect in LLAs may be degraded in tissue culture by extra-cellular hydrolases secreted by the roots (A.D.M. Glass personal communication). If this is the case, alternate protocols may help to avoid such problems by offering more direct delivery to the leaves, such as: application to the surface of infected leaves, 
injection into plant vascular tissue or to the media of virus infected plant protoplasts or animal cells. For example, J.B. Hudson (personal communication) found the crude extract of $F$. gardneri to have high antiviral activity against influenza $A$ and herpes simplex-1, while remaining non-toxic to host cells. Providing that the same compounds affect plant and animal systems, the latter method may be the most effective method for testing the efficacy of compounds against established infection. With fewer steps to confound the assay, compounds could simply be absorbed from surrounding solution and viral effect monitored with ELISA.

In considering the toxicity observed in the most potent of the crude treatments $(10 \mu \mathrm{g} / \mu \mathrm{l})$ of tissue culture, it is important to bear in mind the high concentration and impure nature of the extract. Rather than being relevant to antiviral molecules, phytotoxic symptoms may be the result of elevated ionic concentration or toxicity of compounds not involved in antiviral activity. Although algae are clearly capable of toxicity, results of LLAs in this study and other antiviral studies (Kim et al., 1997) found little toxic effect from active algal fractions. Thus once purified, active algal constituents may not elicit the phytotoxicity observed in the crude $(10 \mu \mathrm{g} / \mu \mathrm{l})$ tissue culture treatment.

As an aside, an algal polysaccharide has been found to reduce toxicity induced by AZT (azidothymidine) in HIV-infected cells. A synergy study looking at $\mathrm{AZT}$ and the algal constituent fucoidan, suggested that the therapeutic dosage of the more toxic AZT may be reduced when used in combination with algal fucoidan (Schaeffer and Krylov, 2000). Like AZT, ribavirin which is a common plant antiviral, is also a nucleoside analog. It is possible that fucoidan or other polysaccharides from Fucus gardneri could supply a similar synergistic effect in plant systems. 


\section{Conclusion}

This study adds to the list of marine algae known to contain plant virus inhibitors and is the first to do so using potato virus $\mathrm{X}$. Local lesion assays identified six of the thirty marine algae to contain compounds which strongly inhibit infectivity of this virus. Of these six, it is the first time that Fucus gardneri, Ralfsia sp. and Fragilaria oceanica have been reported to be a source of antiviral agents. Furthermore, when applied to the leaves of $C$. quinoa none of the 30 algal extracts produced symptoms of toxicity. The clustering of bioactivity in species from the Heterokontophyta is intriguing. Further screening of species belonging to this group and characterization of their active constituents presents an excellent opportunity for future work.

Performance of extracts from $F$. gardneri in both PVX and TMV screening, as well as dilution and compound stability assays clearly identified this species as the most promising for phytochemical analysis. The following chapter will cover the fractionation and isolation of semi-pure and pure active fractions of this alga. Limitations of this study were highlighted by the outcome of systemically infected $S$. tuberosum, these difficulties may be overcome with compound purification or use of alternate assays. Nonetheless the success of this screening emphasizes the potential of marine algae to provide abundant and renewable compounds for treatment of agricultural viruses. In the search to identify new and effective agrochemicals the oceans will without doubt hold many solutions. 


\section{BIBLIOGRAPHY}

Algaebase. 2001. www.algaebase-.com National University of Ireland. Galway.

Beress, A., Wassermann, O., Tahhan, S., Bruhn, T., Beress, L., Kraiselburd, E.N. Gonzalez, L.V. de Motta, G.E. and Chevez, P.I. 1993. A new procedure for the isolation of anti-HIV compounds (polysaccharides and polyphenols) from the marine alga Fucus vesiculosus. Journal of Natural Products 56: 478-488. [Erratum appears in Journal of Natural Products (1996). 59: 552]

Blunden G., and Gordon S. 1986. Betaines and their sulphonio analogues in marine algae. In: Progress in Phycological Research. Volume 4. Edited by: F.E. Round and D.J. Chapman. Biopress Ltd., Bristol. pp. 39-80.

Bold, H.C. and Wynne M.J. 1985. Introduction to the Algae- $2^{\text {nd }}$ Edition. Prentice-Hall. Upper Saddle River. pp. 5-25.

Brunt, A., Crabtree, K., Pallwitz, M., Gibbs, A. and Watson, L. (Editors). 1996. Viruses of plants. Descriptions and lists from VIDE database. CAB International Press. pp. 1030-1033.

Carté, B.K. 1996. Biomedical potential of marine natural products. Marine. organisms are yielding novel molecules for use in basic research and medical applications. Bioscience 46: 271-286.

Cavalier-Smith, T. 1998. A revised six-kingdom system of life. Biological Reviews 73: 203-266.

Chapman, V.J. 1970. Seaweeds and Their Uses. Methuen \& Co. London. pp. 1073.

Clark, M.F., Adams, A.N. and Barbara, D.J. 1976. The detection of plant viruses by enzyme-linked immunosorbent assay (ELISA). Acta Horticulturae 67:43-47.

Duffy, J.E. and Hay M.E. 1990. Seaweed adaptations to herbivory. Bioscience 40: 368-375.

French C.J., Elder, M., Leggett, F. Ibrahim, R.K., Towers, G.H.N. 1991. Flavonoids inhibit infectivity of tobacco mosaic virus. Canadian Journal of Plant Pathology 13: 1-6. 
French, C.J. and Towers, G.H.N. 1992. Inhibition of infectivity of potato virus $\mathrm{X}$ by flavonoids. Phytochemistry 31: 3017-3020.

Fritig, B., Kauffmann, S., Rouster, J., Dumas, B., Geoffory, P., Kopp, M. and Legrand, M. 1990. Defence proteins, glycanhydrolases and oligosaccharide signals in plant-virus interactions. In: NATO ASI series, Vol. H 41. Recognition and Response in Plant-virus Interactions. Edited by: Fraser, R.S.S. Springer-Verlag. Berlin. pp. 375-394.

Fusetani, N. 2000. Introduction. In: Drugs from the Sea. Edited by: Fusetani, N. Karger. New York. pp. 1-5.

Galal A.M., El-Ayouty, Y.M., Hashem S.A. and El-Sabbahy, G. 1999. Screening of different algal extracts for their efficacy against mechanical transmission of two phytoviruses. Acta Hydrobiologica 41:155-163.

Gerber, P., Dutcher, J.D., Adams, E.V. and Sherman, J. H. 1958. Protective effect of seaweed extracts for chicken embryos infected with influenza B or mumps. Proceeding: Society for Experimental Biology and Medicine 99: 590593.

Grabley, S. and Thiericke, R. 1999. Chapter 1- The impact of natural products on drug discovery. In: Drug Discovery from Nature. Edited by: Grabley, S. and Thiericke, R. Springer. New York. pp. 2-33.

Graham, L.E. and Wilcox, L.W. 2000. Algae. Prentice Hall. Upper Saddle River. pp. 8-21.

He H., Ding, W.D., Bernan, V.S., Richardson, A.D., Ireland, C. M., Greenstein, M., Ellestad, G.A. and Carter, G.T. 2001. Lomaiviticins A and B, potent antitumor antibiotics from Micromonospora Lomaivitiensis. Journal of the American Chemical Society 123:5362-5363.

Hudson, J.B., Kim J.H., Lee M.K., Hong Y.K., and DeWreede, R.E. 1999a. Multiple antiviral activities in extracts of seaweed from British Columbia. Pharmaceutical Biology 37: 300-306.

Hudson, J.B., Kim, J.H., Lee, M.K., DeWreede, R.E., and Hong, Y.K. 1999b. Antiviral compounds in extracts of Korean seaweeds: Evidence for multiple activities. Journal of Applied Phycology 10: 427-434.

Hustedt, F. 1985. Die Kieselangen 2 Teil. Koenigstein. New York. pp. 138-139. 
Jensen, P.R. and Fenical, W. 2000. Marine microorganisms and drug discovery: current status and future potential. In: Drugs from the Sea. Edited by: Fustani, N. Karger. New York. pp. 2-29.

Kim, J.H., Hudson J.B., Haung A.M., Bannister K., Jin H., Choi T.J., Towers G.H.N., Hong Y.K., and DeWreede R.E. 1997. Biological activities of seaweed extracts from British Columbia, Canada, and Korea. I. Antiviral activity. Canadian Journal of Botany 75: 1656-1660.

Kleczkowski, A. 1949. The transformation of local lesion counts for statistical analysis. Annals of Applied Biology 36:139-152.

Lee, R. E. 1999. Phycology $3^{\text {rd }}$ Edition. Cambridge University Press. pp. 481-540.

Levring, T. 1979. The vegetation of the sea. In: Marine algae in pharmaceutical science. Edited by: Hoppe, H.A., Levring, T., and Tanaka, Y. Walter de Gruyter. New York. pp. 3-25.

Logeart, D., Prigent-Richard S., Jozefonvicz, and Letourneur, D. 1997. Fucans, sulphated polysaccharides extracted from brown seaweeds, inhibit vascular smooth muscle cell proliferation. I. Comparison with heparin for antiproliferative activity, binding and internalization. European Journal of Cell Biology 74: 376384.

Matthews, R.E.F. 1991. Plant Virology $3^{\text {rd }}$ Edition. Academic Press. Toronto. pp. 423-450.

McConnell, O.J., Longley, R.E. and Koehn, F. E. 1994. The discovery of marine natural products with therapeutic potential. Chp. 5. In: The Discovery of Natural Products with Therapeutic Potential. Edited by: Gullo V. ButterworthHeinemann. Toronto. pp. 109-165.

Munro, M.H.G., Luibrand, R.T. and Blunt, J.W. 1987. The search for antiviral and anticancer compounds from marine organisms. In: Bioorganic Marine Chemistry - Vol. 1. Springer-Verlag. Berlin. pp. 93- 160.

Nakashima, H., Kido, Y., Kobayashi, N., Motoki, Y., Neushel, M., and Yamamoto, N. 1987. Purification and characterization of an avian myeloblatosis and human immunodeficiency virus reverse transcriptase inhibitor, sulphated polysaccharides extracted from sea algae. Antimicrobial Agents and Chemotherapy 31: 1524-1528. 
Neushul, M. 1990. Antiviral carbohydrates from marine red algae. Hydrobiologia 204: 99-104.

O'Clair R. M. and Lindstrom S. C. 2000. North Pacific Seaweeds. Plant Press. Auke Bay.

Padmakumar, K. and Ayyakkannu, K. 1997. Antiviral activity of marine plants. Indian Journal of Virology 13: 33-36.

Paul, V. J. and Fenical, W. 1987. Natural products chemistry and chemical defense in tropical marine algae of the Phylum Chlorophyta. In: Bioorganic Marine Chemistry - Vol. 1. Springer-Verlag. Berlin. pp. 1-30.

Pawlik, J.R. 1993. Marine invertebrate chemical defenses. Chemical Reviews 93 : 1991-1922.

Percival, E. 1970. Algal polysaccharides. In: The Carbohydrates: Chemistry and Biochemistry Vol. IIB $2^{\text {nd }}$ Edition. Edited by: Pigman, W. and Horton, D. Academic Press. New York. pp. 537-568.

Pratt, R. and Fong, J. 1940. Studies of Chlorella vulgaris. Further evidence that chlorella cells form a growth inhibiting substance. American Journal of Botany 27: 431-436.

Rinehart, Jr. K.L., Shaw, P.D., Shield, L.S., Gloer, J.B., Harbour, G.C., Koker, M.E.S., Samain, D., Schwartz, R.E., Tymiak, A.A., Weller, D.L., Cartér, G.T., Munro, M.H.G., Hughes, Jr. R.G., Renis, H.E., Swynenberg, E.B., Stringfellow, D.A., Vavra, J.J., Coats, J.H., Zurenko, G.E., Kuentzel, S.L., Li, L.H., Bakus, G.J., Brusca, R.C., Craft, L.L., Young, D.N. and Conner, J.L. 1981. Marine natural products as sources of antiviral, antimicrobial and antineoplastic agents. Pure and Applied Chemistry 53:795- 820.

Scagel, R.F. 1967. Guide to Common Seaweed of British Columbia. British Columbia Provincial museum: Handbook No. 27.Province of British Columbia, Ministry of the Provincial Secretary and Travel Industry. pp. 36-166.

Schaeffer, D.J. and Krylov V.S. 2000. Anti-HIV activity of extracts and compounds from algae and cyanobacteria. Ecotoxicology and Environmental Safety 45: 208-227. 
Shaw, J.G. 1996. Plant viruses In: Fields Virology: $3^{\text {rd }}$ Edition. Edited by: B.N. Fields, D.M. Knipe, P. M. Howley, R. M. Chanock, T.P. Monath, B. Roizman, J.L. Melnick and Straws, S.E. Lipponcott-Raven Publishers, Philadelphia. 1996. pp. 499-532.

Shimizu, Y. 1993. Microalgal metabolites. Chemical Reviews 93: 1685-1698.

Šutić, D.D., Ford, R.E. and Tošić, M.T. 1999. Handbook of Plant Virus Diseases. CRC Press. New York. pp. 255-256.

Tuomi, J., Ilvessalo, H., Niemela, P. Siren, S. and Jormalainen, V. 1989. Withinplant variation in phenolic content and toughness of the brown alga Fucus vesiculosus L. Botanica Marina 32: 505-509.

University of Columbia in the City of New York. 2001. http://www.ncbi.nlm.nih.gov/ICTVdb/ICTVdB/56010000.htm. New York.

Van Den Hoek, C., Mann, D.G. and Jahns, H.M. 1995. Algae: an Introduction to Phycology. Cambridge University Press. Cambridge. pp. 103-168.

Volkman, J.K. 1999. Australasian research on marine natural products: chemistry, bioactivity and ecology. Marine and Freshwater Research 50: 761-779.

Wambugu, F.M., Secor, G.A. and Gudmestad, N.C. 1985. Eradication of potato virus $\mathrm{Y}$ and $\mathrm{S}$ from potato by chemotherapy of cultured axillary bud tips. American Potato Journal 62:667-672.

Witvrouw, M. and De Clercq, E. 1997. Sulfated polysaccharides extracted from sea algae as potential antiviral drugs. General Pharmacology 29: 497-511.

Zaitlin, M. and Palukaitis, P. 2000. Advances in understanding plant viruses and virus diseases. Annual Review of Phytopathology 38:117-143. 


$$
\text { Cbapter } 3
$$

\section{Fractionation of Antiviral Compounds from Fucus gardneri}

\section{Introduction}

Work to this point has identified several species of marine algae that exert a strong antiviral effect against PVX in local lesion assays (LLAs). Fucus gardneri was chosen over other species because of its potency in screening and dilution assays, local abundance and the stability of its biological activity. Fucus gardneri belongs to the order Fucales and is also known by the common names bladderwrack or bubble kelp. It can be found in abundance on rocks of the mid intertidal in a range stretching from central Califomia to the Bering Sea, Chukchi Sea and Kamchatka (Figure 3.1). It forms a short and often dense canopy $(<50 \mathrm{~cm})$ and is ecologically important as a source of food and protection from wave action and desiccation. Attached to rocks by a small discoid holdfast, a short stipe supports its flat, dichotomously branched thallus. At maturity, the tips of its branches are densely packed with gamete filled conceptacles. Living for between 2-5 years, individuals reproduce throughout the year (O'Clair and Lindstrom, 2000). Although the lifecycle involves alternation of generations, the haploid generation of $F$. gardneri is limited to the egg and sperm (Lee, 1999).

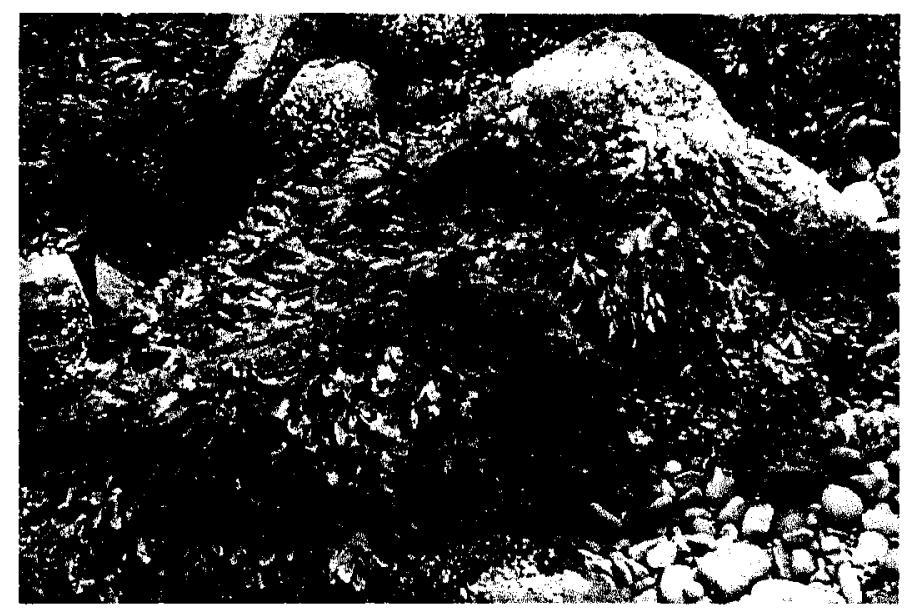

Figure 3.1: Fucus gardneri found growing densely on intertidal rocks of North Pacific coast. Source: King County Washington, 2001. 


\section{BACKGROUND}

The goal of this phase of the project was to isolate and identify the compounds in $F$. gardneri that are responsible for the anti-PVX effects observed in chapter two. Based on a review of human virus research literature, the constituents of marine algae likely to have antiviral activity include: polyphenols, sulphated polysaccharides and peptides (Nakashima et al., 1987; Baba et al., 1988; Beress et al., 1993; Boyd et al, 1997; Hudson et al., 1999a,b). Few studies have evaluated the therapeutic potential of $F$. gardneri. There was no bioactivity in a screening against herpes simplex-1 and Sindbis viruses (Kim et al., 1997); however, concentrations of aqueous. $F$. gardneri extract as low as $20 \mu \mathrm{g} / \mathrm{ml}$ did inhibit Taq DNA polymerase (Jin et al., 1997). Nonetheless, there is no direct evidence of antiviral activity from $F$. gardneri.

Although I could not find specific studies on $F$. gardneri, previous work on the order Fucales has identified several hundred primary and secondary metabolites within the larger taxon (Valls and Piovetti, 1995). Phenolic compounds include phloroglucinol and other simple phenols like pyrogallol, catechol, resorcinol and hydroquinone (Waterman and Mole, 1994). The Fucales are also rich in diterpenes and compounds of mixed terpenoid shikimate biosynthetic origin (Valls and Piovetti, 1995). Fucus vesiculosus contains an

abundance of phlorotannins and the polysaccharides alginic acid and fucoidan (Beress et al., 1993). The biosynthetic origin of algal metabolites tends to be less complicated than in land plants. Below is a review of algal metabolites in $F$. gardneri considered to be primary candidates as sources of the observed antiPVX activity.

\section{Polysaccharides}

Marine algae have a rich diversity of polysaccharides, which consist of both linear and branched chains (Lehninger et al., 1993) and serve a variety of 
roles by providing mechanical strength (Witvrouw and De Clerq, 1997), protection from desiccation, food storage (Percival, 1970) and perhaps even a mechanism for ion exchange (Eppley, 1958). Although variation occurs within each taxon, different forms of polysaccharides are characteristic of each of the major algal groups. Members of the Chlorophyta contain: starch, inulin, cellulose, $D$-mannans, $\beta$-D-xylans and mucilages (complex assemblages of carbohydrate, protein and sulphur). The Rhodophyta is characterized by: floridean starch, cellulose, $\beta$-D- $(1 \rightarrow 4)$ mannans, $\beta$-D-xylans and sulphated galactans (i.e.: agars and carrageenans). The major polysaccharides of the Heterokontophyta include cellulose, alginate, fucoidan and laminarin or chrysolaminarin (Painter, 1983).

\section{Cellulose}

Cellulose is the only glycan that the Heterokontophyta shares with land plants. Although it is defined as a linear polymer of $\beta$-D-glucopyranose, algal cellulose often also contains mannose or xylose residues (Painter, 1983). As a principal component of cell walls, cellulose provides structure and strength to plants (Lehninger et al., 1993). Due to its high molecular weight and strong associative properties, cellulose is only soluble under special conditions. Consequently, it is not likely that cellulose is involved in the observed bioactivity of methanolic extracts (Whistler and Smart, 1953).

\section{Alginate}

Alginate, the most well known polysaccharide of brown algae, is a collective term that refers to a family of linear $(1 \rightarrow 4)$-linked $\alpha$-L-gulurono- $\beta$-Dmannuronans (Painter, 1983). These polyuronides are commercially important in food, dental and pharmaceutical applications (Percival, 1970). The key role of alginate in brown algae is structural, contributing as much as $40 \%$ of the dry weight. Alginate occurs as cationic salts (i.e.: $\mathrm{Na}^{+}, \mathrm{Mg}^{2+}, \mathrm{Ca}^{2+} \& \mathrm{~K}^{+}$). Sodium salts of alginate are water-soluble, whereas alginates cross-linked with calcium or other 
cations are completely insoluble (Van Den Hoek et al., 1995). During extraction, I exploited this property by using $\mathrm{Na}_{2} \mathrm{CO}_{3}$ in an ion exchange reaction that transformed insoluble, mixed cation alginate into soluble sodium alginate (Haug, 1974).

\section{Fucoidan}

Fucoidans are sulphated L-fucans and although found in all brown algae, they are especially abundant in intertidal species such as $F$. gardneri. Fucoidans are found in intercellular tissues and extracellular exudates (Painter, 1983). They are extremely hygroscopic and are exuded by brown algae in the intertidal as protection against desiccation (Percival, 1970). As a consequence, the fucoidan content of this species depends on where individuals occur in the littoral zone (Lee, 1999). Although slightly soluble in aqueous solutions (w/v 3\%), extraction of fucoidan under acidic conditions greatly increases yield (Percival and McDowell, 1967).

\section{Laminarin}

Found in all brown algae, laminarin, as the name suggests, was first isolated from the genus Laminaria. Laminarin is a food reserve and the abundance varies throughout the year, being plentiful in the autumn and winter and absent in the spring. Laminarins are $(1 \rightarrow 3)$-linked $\beta$-D-glucopyranans containing 16 to 31 sugar residues and, unlike the previously described polysaccharides, are usually branched (Painter, 1983). The degree of branching as well as periodic $1 \rightarrow 6$ linkages and terminal mannitol residues introduce variation to different forms of laminarin (Lee, 1999). A high number of $1 \rightarrow 6$ linkages and/or branching points dramatically increase the solubility of these molecules, with many forms being soluble in cold water (Percival, 1970). 


\section{Phenolics}

The term "phenolic" refers to a family of compounds containing an aromatic ring with one or more hydroxyl substituents. Such compounds are not directly involved in the primary metabolism and therefore are considered to be secondary metabolites (Mann, 1987). With the exception of one family of green algae, the Charophyceae, compounds from the shikimic acid pathway, such flavonoids and hydrolysable tannins, are absent in algae. Instead, metabolites such as phlorotannins, which are derived entirely from acetate, are found in abundance (Waterman and Mole, 1994).

Phlorotannins contribute as much as $10 \%$ to the dry weight (Ragan and Glombitza, 1986). Carbon-carbon and carbon-oxygen bonds link monomers of phloroglucinol (1,3,5-trihydroxybenzene) into polymers of various molecular weights (Haslam, 1998; McInnes et al., 1985). Variations on the basic chemical structure include the addition of halogens, sulphates, hydroxyls and alkenyl side chains (Ragan, 1985).

Once considered to be waste products, such secondary metabolites are now recognized to mediate a host of ecological interactions. Although structurally different from polyphenols of land plants, phlorotannins are functionally similar (Tuomi et al., 1989). One role for such compounds may be as nonspecific allelochemicals important in the regulation of endophytes, epiphytes, and bacteria and in herbivory (Lee, 1999).

\section{Amino-based algal compounds}

Polysaccharides and polyphenols are certainly the most widely reported classes of bioactive algal compounds; however, other algal substances have excellent therapeutic potential (Schaeffer and Krylov, 2000). One set of compounds that appear to be involved in the anti-PVX activity of $F$. gardneri are those which have amino groups. Amino functionalities occur widely in biological chemicals; however, this review will consider peptides, betaines and lectins. 


\section{Peptides}

There is a growing awareness of the potential of peptides in therapeutic applications (Schaeffer and Krylov, 2000). Naturally occurring polypeptides range in length from two or three amino acids to more than a thousand. Large peptides are not easily extracted and may be degraded (Lehninger et al., 1993), consequently I emphasize smaller peptides. These smaller peptides are considered to be most therapeutically relevant, because of uptake and physiological effects (Prasad, 1995). The small peptides, which have been isolated from algae are rich in arginine, asparagine or glutamine residues, although their function remains unknown. Nitrogen storage is a likely possibility (Higgins and Payne, 1982). An example of a very active antiviral peptide comes from the cyanobacterium, Nostoc ellipsosporum. This peptide, cyanovirin-N, has been selected for detailed study by the U.S. National Cancer Institute because of its potent action against HIV infection (Boyd et al., 1997).

\section{Lectins and Betaines}

Lectins are proteins that specifically bind to carbohydrates, such as the glycans found on the envelope of some viruses. Lectins are found in both plants and animals, but their physiological role remains unclear, in part because lectins do not appear to have catalytic activity (Lehninger et al., 1993). To date, no algal lectins have been implicated in antiviral activity. This may be more a consequence of research focus rather than a reflection of the bioactivity of algal lectins (Schaeffer and Krylov, 2000).

Betaines are methylated derivatives of amino and imino acids. Although not previously implicated in antiviral activity, they have been associated with crop stress reduction and are abundant in many algae (Blunden and Gordon, 1986). One, $\gamma$-aminobutyric acid betaine, found in Fucus sp. has recently been linked to the stimulation of plant defense response (Jenkins et al., 1998) and is also well known for potent physiological effects in mammals (Liu et al., 1993). 


\section{Methods and Materials}

\section{Preliminary Phytochemistry}

\section{Local lesion assays}

Unless specified, all LLAs discussed in this chapter were performed at a standard concentration of $10 \mu \mathrm{g} / \mu \mathrm{l}$ as described in chapter 2. Most LLAs in this chapter were used as a tool for bioassay guided fractionation to direct isolation procedures. Results from these assays should be interpreted generally in this sense, not quantitatively.

\section{Extraction of $F$. gardneri over a time course}

The general polarity of bioactivity was determined by extracting $F$. gardneri with solvents of varying polarity. Each treatment began with $20 \mathrm{~g}$ of dried plant material infused with $100 \mathrm{ml}$ of hexane or methanol (unless specified all organic solvents used were ACS grade, Fisher). Samples $(20 \mathrm{ml})$ were collected at 1 minute, $2 \frac{1}{2}$ and 26 hours, dried in vacuo and assayed for bioactivity using LLAs.

\section{Preparatory Thin-layer Chromatography}

To determine the general polarity and position of bioactivity in the thinlayer chromatography (TLC) profile of the crude extract, two preparatory TLC plates (silica gel $60 \quad \mathrm{~F}_{254}, \mathrm{EM}$ Science) were developed using a chloroform:methanol solvent system $(13: 1) \mathrm{v} / \mathrm{v}$. The plates were allowed to dry and elution profiles were determined using long and short wave UV lamps (UltraViolet Products inc.). Silica from individual UV visible bands was transferred to borosilicate tubes and extracted with $10 \mathrm{ml}$ methanol. This was repeated four times or until all color had eluted from the silica. Extracts of each band were dried in vacuo and assayed for bioactivity using LLAs. 
Silica Gel Column Chromatography (Si-1)

This first column chromatography served to correlate further the elution profile with bioactivity. Using $25 \mathrm{~g}$ of silica (70-230 mesh, Merck) in a $2 \times 30 \mathrm{~cm}$ column, $75 \mathrm{mg}$ of crude extract was fractionated with a chloroform:methanol:acetone $(9: 1: 0-6: 3: 3) \mathrm{v} / \mathrm{v} / \mathrm{v}$ gradient yielding $154 \times 10 \mathrm{ml}$ fractions. Fractions were grouped according to TLC profile, dried in vacuo and assayed for bioactivity individually $(10 \mu \mathrm{g} / \mu \mathrm{l}$ and $20 \mu \mathrm{g} / \mu \mathrm{l})$ or in combination to test for synergy.

\section{Autoclaving}

As part of a tissue culture experiment, $100 \mathrm{mg}$ crude methanol extract was autoclaved for 15 minutes at a temperature of $120^{\circ} \mathrm{C}$. Following autoclaving, sample was assayed for bioactivity using LLAs.

\section{Methylation using diazomethane}

Crude and semi-pure extracts were methylated in an effort to overcome difficulties in chemical isolation due to the extreme polarity of bioactive fractions. Methylated compounds are less polar and once isolated they can be demethylated using sodium hydroxide. This reaction was carried out using a diazomethylation kit (Aldrich Chemical Co.). The procedure relies on a reaction between diazald and an alcoholic alkali to produce diazomethane. Due to the toxicity of diazomethane and the risk of explosion, all preparations and the reaction were carried out in the fume hood.

Reagents $(1 \mathrm{ml}$ diethyl ether, $1 \mathrm{ml}$ carbitol (monoethyl ether ethylene glycol) and $0.4 \mathrm{~g}$ of diazald (Aldrich Chemical Co.)) were combined in the inner reaction vessel and the algal extract was dissolved in $3 \mathrm{ml}$ of diethyl ether and placed in the bottom of the outer vessel. The two vessels were assembled with an o-ring and a clamp. The base of the apparatus was placed in an ice bath to dissipate heat. Using a narrow gauge syringe, $37 \%$ potassium hydroxide $(0.5$ to 
1.5ml, BDH Chemical Co.) was carefully injected drop wise through the silicone rubber septum into the inner reaction vessel to begin the generation of diazomethane. The reaction rate was accelerated by gently shaking the apparatus every 10 minutes for the first 30 minutes and allowed to run overnight. The apparatus was disassembled and the diethyl ether was evaporated from the sample under a stream of nitrogen gas. Thin-layer chromatography (hexane:ethyl acetate 3:7) v/v and LLAs were used to follow changes to the extract.

\section{Amberlite XAD-2 Column Chromatography (A-1)}

Amberlite XAD-2 column chromatography (Beress et al., 1993) was used to isolate the polyphenol portion of the crude extract. Amberlite XAD-2 is a polymeric divinylbenzene reverse-phase adsorbent with a high affinity for aromatic substances; thus is suitable for the isolation of alga phlorotannins (Gregson and Daly, 1982). A column $(2 \times 40 \mathrm{~cm})$ was prepared by adding presoaked Amberlite XAD-2 beads (Sigma) in water, followed by 2 volumes of methanol and water to wash the column. Crude extract $(60 \mathrm{mg})$ was charged to the column in a minimal volume of water and eluted using a water:acetonitrile gradient $(100: 0-50: 50) \mathrm{v} / \mathrm{v}$. followed by a final wash with $3 \mathrm{M}$ ammonium hydroxide (Fisher). The final fraction $(\mathrm{pH} 11.4)$ was neutralized using dilute hydrochloric acid to a $\mathrm{pH}$ of 6.5 . The resulting ammonium chloride was then separated from algal constituents by washing the fraction with acetonitrile. Fractions were grouped according to TLC profile and assayed for bioactivity using LLAs.

\section{Polyamide Minicolumns}

This method was designed to remove $99 \%$ of polyphenolic compounds from plant extracts, thus allowing for the evaluation of their possible role in bioactivity (Collins et al., 1998). Holes were drilled in the base and lid of several plastic $1.5 \mathrm{ml}$ micro-centrifuge tubes (Dia Med) using a 20-gauge needle. A small 
amount of glass wool was packed at the base of each tube and an aqueous suspension of $\mathrm{CC} 6$ polyamide poured (Macherey-Nagel, Germany) to form a bed approximately $1 \mathrm{~cm}$ deep. The micro-centrifuge tubes were then placed in the neck of $13 \times 100 \mathrm{~mm}$ glass test tubes and the polyamide in the minicolumn was rinsed with water and packed by centrifugation (GLC-1, Sorvall) for one minute $(1000 \mathrm{xg})$ three times. One millilitre of aqueous extract $(\leq 25 \mathrm{mg} / \mathrm{ml})$ was applied to the column. Extracts were allowed to percolate and the column was rinsed with $1 \mathrm{ml}$ of distilled water and centrifuged for 1 minute as before and the eluate collected. This procedure was repeated with $1 \mathrm{ml}$ methanol:water (50:50) v/v and $1 \mathrm{ml}$ methanol. Fractions were dried in vacuo and assayed for bioactivity using LLAs.

\section{Dialysis}

An approximation of relative molecular weight was achieved using dialysis. Algal fractions were dissolved in a minimal volume of distilled water and dialyzed through a cellulose membrane (M.W. cut-off 12,000; Sigma). The surrounding solution of distilled water $\left(4^{\circ} \mathrm{C}\right)$ was stirred constantly and replaced at intervals of $6,21,48$ and 72 hours. These dialysate fractions were collected along with the final contents of the membrane, dried in vacuo and assayed for bioactivity using LL_As.

\section{Sephadex LH-20 Column Chromatography (Se-1)}

Sephadex LH-20 separates compounds primarily on the basis of molecular exclusion; resulting in further purification of active fractions based on differences in molecular weight. Sephadex beads (Pharmacia) were soaked for 4 days in methanol:chloroform (4:1) v/v, degassed in vacuo with constant stirring and poured to prepare a $2 \times 40 \mathrm{~cm}$ column, which was rinsed with two volumes of methanol:chloroform (4:1) $\mathrm{v} / \mathrm{v}$. The sample was a butanol fraction obtained from liquid partitioning. The fraction $(49 \mathrm{mg})$ was applied to the column in a 
minimal volume of water-saturated butanol and eluted using a gradient of methanol:water $(100: 0-50: 50) \mathrm{v} / \mathrm{v}$.

\section{PHYTOCHEMISTRY}

\section{Extraction and liquid/liquid Partitioning}

The scale of extraction was increased using fresh material. Ten kilograms of $F$. gardneri was collected from Acadia Beach, Vancouver (49 $17^{\prime} \mathrm{N}, 123^{\circ} 14^{\prime}$ W) in December 2000. Material was washed, dried and ground, as previously described. Plant material was extracted at $45^{\circ} \mathrm{C}$ four times in $4 \mathrm{~L}$ volumes of methanol. The supernatant was dried under vacuum at $35^{\circ} \mathrm{C}$ as previously described to produce a dried crude extract. The crude extract was suspended in $1200 \mathrm{ml}$ of distilled deionized water and partitioned against hexane $(3800 \mathrm{ml})$ in two 2L separatory funnels. Once separated, the water fraction was dried under vacuum to remove residual hexane and then partitioned against ethyl acetate $(2400 \mathrm{ml})$. Fractions were separated and residual ethyl acetate was removed from the water fraction in vacuo, which was then partitioned against butanol $(1200 \mathrm{ml})$. All four fractions were dried under vacuum and then assayed for bioactivity using LLAs.

\section{Silica gel column chromatography (Si-2)}

Based on results from previous silica gel columns, silica gel chromatography of the ethyl acetate fraction provided a further purification step. Using a silica to extract ratio of 1:25 the column $(5 \times 40 \mathrm{~cm})$ was filled with $325 \mathrm{~g}$ of silica (600 mesh, Merck) and charged with the extract mixed with 62g silica (1:5) w/w. The column was eluted using a gradient solvent system with hexanes:acetone $(80: 20-0: 100) \mathrm{v} / \mathrm{v}$ and then with acetone:methanol (100:0 $0: 100) \mathrm{v} / \mathrm{v}$. 
Sephadex LH-20 Column chromatography (Se-2)

Following silica chromatography, fractions were subjected to further purification using Sephadex LH-20 column chromatography (see $\mathrm{Se}-1$ above). Active fractions $(3 \mathrm{~g})$ from silica gel chromatography $(\mathrm{Si}-2)$ were pooled (fractions 53-78) and applied in a minimal volume of methanol to a column $(5 \times 30 \mathrm{~cm})$ prepared with $30 \mathrm{~g}$ Sephadex LH-20 beads. The column was eluted using an isocratic single solvent system beginning with $100 \%$ methanol $(1500 \mathrm{ml})$, followed by $100 \%$ acetone $(650 \mathrm{ml})$.

\section{Characterization of Bioactivity}

\section{Spray reagents}

Active fractions collected during this study were partly characterized using the following spray reagents (Stahl, 1969). Unless specified otherwise, all TLC was performed using aluminum silica gel $60 \mathrm{~F}_{254}$ plates (EM Science).

Ninhydrin (Stahl, 1969)

Ninhydrin reagent was prepared by dissolving $0.2 \mathrm{~g}$ ninhydrin (Fisher) in $100 \mathrm{ml}$ ethanol. TLC plates were sprayed with the reagent and heated to $110^{\circ} \mathrm{C}$. Positive reaction for amino acids, amines and aminosugars was indicated by the development of a pink/purple color.

Phenol sulphuric acid (Stahl, 1969)

Reagent was prepared by dissolving $3 \mathrm{~g}$ phenol (Fisher) and $5 \mathrm{ml}$ concentrated sulphuric acid (Anachemia) in $95 \mathrm{ml}$ ethanol. TLC plates were developed, sprayed and heated at $100^{\circ} \mathrm{C}$ for $10-15$ minutes. Bands containing sugars or glucosides were indicated by the development of a brown or yellow color. 
Vanillin sulphuric acid (Stahl, 1969)

This reagent which is a general spray reagent identifying most organic compounds including higher alcohols, phenols, steroids and essential oils, was prepared by combining $1 \mathrm{~g}$ vanillin (Sigma) with $100 \mathrm{ml}$ concentrated sulphuric acid (Fisher). Once plates were sprayed, color development was accelerated by heating at $120^{\circ} \mathrm{C}$.

\section{Folin-Ciocalteu reagent (Stahl, 1969)}

This reagent, which is specific for phenolic compounds, was prepared by combining $10 \mathrm{~g}$ sodium tungstate (BDH Chemical Co.) and $2.5 \mathrm{~g}$ sodium molybdate (BDH Chemical Co.) in $70 \mathrm{ml}$ of water. To this, $5 \mathrm{ml}$ of $85 \%$ phosphoric acid (Fisher) and 10ml of 36\% hydrochloric acid (Fisher) was added. The mixture was then refluxed for 10 hours. After cooling, $15 \mathrm{~g}$ lithium sulphate (BDH Chemical Co.), $5 \mathrm{ml}$ water and 1 drop of bromine were added and the solution refluxed for a further 15 minutes. To develop TLC plates with this reagent, plates were first sprayed with $20 \%$ aqueous sodium carbonate (MCB Reagents) followed by spraying with a three times dilution of the stock solution. Bands containing phenolic compounds were indicated by the development of a grey color.

Dragendorff's reagent (Stahl, 1969)

Three variations of this reagent were prepared because of subtle differences in specificity. All were used to identify nitrogen-containing compounds containing quaternary nitrogen, including betaines. Heating was not required to produce a yellow to red color change indicating positive reactions.

1. Reagent was prepared by dissolving $8 \mathrm{~g}$ of bismuth nitrate (Baker and Adamson) in $20 \mathrm{ml}$ of $25 \%$ nitric acid ( $\mathrm{v} / \mathrm{v}$ ) (Anachemia). The solution was mixed into a slurry of $20 \mathrm{~g}$ potassium iodide (Sigma) with $1 \mathrm{ml} 6 \mathrm{M}$ 
hydrochloric acid (Fisher) and $5 \mathrm{ml}$ distilled water. The solution was diluted with water until a red-orange color developed and filtered.

2. Reagent was prepared by dissolving $0.85 \mathrm{~g}$ bismuth nitrate (Baker and Adamson) into $50 \mathrm{ml}$ of $25 \%$ acetic acid (v/v) (Fisher). A second solution of $8 \mathrm{~g}$ potassium iodide (Sigma) dissolved in $20 \mathrm{ml}$ water was added in equal proportions. The spray reagent was prepared by combining $1 \mathrm{ml}$ of the above stock solution with $2 \mathrm{ml}$ of acetic acid (Fisher) and $10 \mathrm{ml}$ of water.

3. Reagent was prepared by briefly boiling $25 \mathrm{ml}$ acetic acid, $2.6 \mathrm{~g}$ bismuth carbonate (MCB Reagents) and 7g sodium iodide JT Baker Chemical Co.). The solution was allowed to stand for 12 hours after which the abundant sodium acetate precipitate was removed by filtration. Twenty milliliters of the above solution were combined with $80 \mathrm{ml}$ ethyl acetate and $0.5 \mathrm{ml}$ water. The spray reagent was prepared by combining $10 \mathrm{ml}$ of the above stock solution with $100 \mathrm{ml}$ acetic acid and $240 \mathrm{ml}$ of ethyl acetate.

\section{Lindt reagent (Ragan and Craigie, 1976)}

Mix 1\% (w/v) vanillin (Sigma) with a solution of 1 part $6 \mathrm{M}$ hydrochloric acid (Fisher) and 9 parts $95 \%$ ethanol. The presence of phloroglucinol is indicated by development of a red color.

\section{Phloroglucinol reagent (Ragan and Craigie, 1976)}

This reagent was used to identify the presence of phloroglucinol. It was made by preparing an aqueous solution of $0.1 \%(\mathrm{w} / \mathrm{v})$ ferric chloride (Baker and Adamson) and $0.1 \%(\mathrm{w} / \mathrm{v})$ potassium ferricyanide (JT Baker Chemical Co.). 


\section{Characterization of Fraction A}

Dialysis

Fraction A originates from Sephadex LH-20 column chromatography (Se-2) of extracts from Fucus gardneri (Figure 3.9). This fractionation led to the isolation of two active fractions, $A$ and $B$, with fraction $A$ being of lower molecular weight. Dialysis was used to obtain the crude approximation of the relative molecular weights of bioactive molecules in fractions $\mathrm{A}$ and $\mathrm{B}$.

\section{Amberlite IR-120 Column Chromatography (A-2)}

This method (Blunden and Gordon, 1986) was used to isolate betaines and other quaternary ammonium or tertiary sulphonium compounds. Amberlite IR-120 ion exchange resin (Mallinckrodt) was pre-soaked in water overnight and $100 \mathrm{mg}$ of water-soluble crude extract was applied to the column. The column was eluted with $500 \mathrm{ml}$ of distilled water followed by $300 \mathrm{ml}$ of $3 \mathrm{M}$ ammonium hydroxide ( $\mathrm{pH} 11.5$, Fisher). The fraction was immediately neutralized with dilute hydrochloric acid (Fisher) to $\mathrm{pH}$ 6.5. Ammonium chloride was removed from this latter fraction by partitioning with butanol. Fractions were assayed for bioactivity using LI.As.

\section{Acid-Urea Gel Electrophoresis}

This method is designed to detect and isolate small cationic peptides. The protocol was provided by Dr. R.E.W. Hancock's research group (Department of Microbiology, University of British Columbia). The algal fraction was fraction A (fractions 6-9) from Sephadex LH-20 column (Se-2). The gels were poured and run using a Bio-Rad (U.S.A.) mini-gel system. The acrylamide solution was prepared by combining $3.2 \mathrm{~g}$ urea (Baker and Adamson), $5.33 \mathrm{ml}$ acrylamide:bisacrylamide (30:0.8 w/w, Bio-Rad), $1.33 \mathrm{ml}$ water and $0.2 \mathrm{ml} 10 \%$ ammonium persulfate $w / v$ (Bio-Rad). Gels were made by adding $30 \mu$ of TEMED (Bio-Rad) catalyst, mixing thoroughly and immediately pouring into 
moulds. The loading comb was placed directly into the top of the running gel. Once set, gels were pre-electrophoresed to remove the ions with a running buffer of $5 \%$ acetic acid (Fisher). Run in reverse polarity at $150 \mathrm{v}$, pre-electrophoresis continued until the current remained constant (1-2 hours). Poured gels were wrapped in Saran wrap and refrigerated overnight.

Samples were loaded in a sample solution, which was prepared as follows. A 10M urea (Baker and Adamson) solution was treated with Bio-Rad AG501-X8 mixed bed resin for the removal of anions from the solution. The sample solution was then prepared by combining $900 \mu \mathrm{l}$ of treated $10 \mathrm{M}$ urea with $50 \mu \mathrm{l}$ water and $50 \mu$ l of acetic acid (final concentrations $9 \mathrm{M}$-urea/5\% acetic acid), to which a small amount of methyl green was added as a tracking dye. The extract was then dissolved $(20 \mathrm{mg} / \mathrm{ml})$ in $5 \%$ acetic acid and mixed 2:1 v/v with the sample solution. $20 \mu \mathrm{l}$ aliquots were loaded into wells at the following concentrations: undiluted, $1 / 1,1 / 10,1 / 100$ and $1 / 1000$. The gel was run in reverse polarity at $150 \mathrm{v}$ for $1 \frac{1}{2}$ hours and at $15 \mathrm{v}$ overnight. The gel was stained using Coomassie blue (9 parts water:methanol (1:1) v/v, 1 part glacial acetic acid and $0.25 \mathrm{~g} / 100 \mathrm{ml}$ brilliant blue R-270(Sigma)) and destained using water:ethanol:glacial acetic acid (Fisher) (9:9:2) v/v/v.

\section{SDS-Polyacrylamide Gel Electrophoresis}

Sodium dodecylsulphate-polyacrylamide gel electrophoresis (SDS-PAGE) in a Bio-Rad (U.S.A.) mini-gel system was used to detect and separate total protein in fraction $\mathrm{A}$. The running gel was produced by combining the following ingredients in a Falcon tube: $1.3 \mathrm{ml}$ distilled water, $1.25 \mathrm{ml} 1.5 \mathrm{M}$ Tris- $\mathrm{HCl}(\mathrm{pH} 8.8$, BDH Chemical Co.), $25 \mu \mathrm{l} 20 \%$ SDS (BDH Chemical Co.), $2.5 \mathrm{ml} 30 \%$ acrylamide (Bio-Rad) and 25 $\mu 1$ 10\% ammonium persulphate w/v (Bio-Rad). Addition of $2.5 \mu \mathrm{l}$ of TEMED (Bio-Rad) catalyzed polymerization. The solution was then mixed and immediately poured between glass plates of the Bio-Rad mini-gel 
apparatus. The top of the running gel was immediately covered with a layer of isobutanol saturated with water to ensure a flat surface. The running gel was topped with a stacking gel for better separation. After allowing 40 minutes for the running gel to polymerize, the isobutanol was washed off with distilled water and the stacking gel was poured over top of the running gel. The stacking gel solution was prepared by combining $1.5 \mathrm{ml}$ distilled water, $625 \mu \mathrm{l} 0.5 \mathrm{M}$ Tris- $\mathrm{HCl}(\mathrm{pH} 6.8)$, $12.5 \mu \mathrm{l}$ of $20 \% \operatorname{SDS}, 325 \mu \mathrm{l}$ of $30 \%$ acrylamide and $12.5 \mu \mathrm{l} 10 \%$ ammonium persulphate $\mathrm{w} / \mathrm{v}$. As before, the polymerization was initiated by the addition of 2.5 $\mu$ l TEMED catalyst. Once poured, combs were placed at the top of the gel and solution was allowed to set for 1 hour. The algal extract used in this experiment was fraction $A$ that had been further purified by boiling (described below- P-1). Proteins in fraction A $(1.5 \mathrm{mg})$ were denatured prior to electrophoresis by adding $40 \mu \mathrm{l}$ of loading buffer $(15 \mu \mathrm{l}$ mercapto-ethanol (Sigma) and $400 \mu \mathrm{l}$ distilled water), sonicating and then heating at $90^{\circ} \mathrm{C}$ for 20 minutes. The entire $40 \mu \mathrm{l}$ sample was loaded into one lane and the gel was run using running buffer $(2.3 \mathrm{mM}$ Tris $\mathrm{pH} 8.3,19.2 \mathrm{mM}$ glycine, $0.1 \% \mathrm{SDS})$ at $250 \mathrm{v}$ for 40 minutes. Once complete the gel was removed from glass plates and dyed in Coomassie blue stain ( 9 parts water:methanol (1:1) v/v, 1 part glacial acetic acid and $0.25 \mathrm{~g} / 100 \mathrm{ml}$ brilliant blue R-270) for one hour, destained for 2 hours in a solution of water:ethanol:glacial acetic acid (9:9:2) v/v/v and photographed using AlphaImage 1200 (Alpha Innotech Corporation).

\section{Polyamide minicolumn}

A portion of fraction A (fractions 14-20@25mg/ml) was applied to polyamide columns and eluted with distilled, deionized water. Activity of the eluted solution was compared in LLAs to the original activity of fraction A. 


\section{Phloroglucinol experiment}

To explore the possibility that phloroglucinol had an antiviral effect, a phloroglucinol standard (1,2,5-trihydroxybenzene, BDH Chemical Co.) was assayed for bioactivity against PVX. In addition, crude and semi-pure active fractions were chromatographed against a phloroglucinol standard in TLC. Plates were run using ether:ethanol:ethyl acetate:water $(14: 11: 5.5: 3) \mathrm{v} / \mathrm{v} / \mathrm{v} / \mathrm{v}$ and then sprayed with phloroglucinol specific spray reagents (Ragan and Craigie, 1976).

\section{Polyamide Column chromatography (P-1)}

Preliminary experiments found that polyamide mini-columns fractionated bioactivity in fraction A. As a result the process was scaled-up and applied to the entire fraction A (pooled with material from an earlier column, total-3.75g). In an attempt to solubilise fraction A for chromatography, the material was boiled in water for 2 seconds using a microwave, vortexed, immediately cooled and then centrifuged. The supernatant was verified to be antiviral using LLAs and then applied to the CC 6-AC polyamide $(70 \mathrm{~g})$ (Macherey-Nagel, Germany) column. The column was washed with an isocratic solvent system beginning with water $(100 \%)$, then water:methanol (50:50), methanol $(100 \%)$ and finally acetone $(100 \%)$. Fractions were clustered into 11 groups based on the TLC profile and assayed for bioactivity using LLAs.

\section{Characterization of Fraction B}

\section{Dialysis}

Fraction B originates from Sephadex LH-20 column chromatography (Se-2) of extracts from Fucus gardneri (Figure 3.9). This fractionation lead to the isolation of two active fractions, A and B, with fraction $\mathrm{B}$ being of higher molecular weight. Dialysis was used to obtain a crude approximation of the relative molecular weights of fractions $\mathrm{A}$ and $\mathrm{B}$. 


\section{Determination of sugars and related substances}

This method (Dubois et al., 1956) was used to confirm the presence of carbohydrates in fractions thought to contain polysaccharides. The reaction was carried out using test tubes with an internal diameter of $16-20 \mathrm{~mm}$ to allow for good mixing while not allowing heat to dissipate too quickly. Agar (5.6mg; BDH Chemical $\mathrm{Co}$.) was used as a positive control and distilled water was the negative control. Sample (6.1 mg fraction B) or controls were added to $2 \mathrm{ml}$ distilled water, $50 \mu$ of phenol:water (80:20) v/v, and $5 \mathrm{ml}$ of $95 \%$ sulphuric acid (Anachemia). Tubes were allowed to stand for 10 minutes, shaken and placed in a $25^{\circ} \mathrm{C}$ water bath for 20 minutes. A color change to yellow or brown indicated the presence of carbohydrates in the sample.

\section{Ethanol Precipitation of Polysaccharides}

Originally designed as a rapid method for dereplication of extracts containing sulphated polysaccharides in screening programs (Beutler et al., 1993), this method was used to assess the role, if any, of sulphated polysaccharides in the bioactivity of $F$. gardneri. "The process of dereplication seeks to select a small subpopulation of hits identified in a primary screen that are most likely to contain active compounds with the desired characteristics." In this case ethanol precipitation removes polysaccharides which are often ubiquitous in marine extracts (Collins et al., 1998). An aqueous solution of each crude methanolic or aqueous extract was prepared to a final concentration of $50 \mathrm{mg} / \mathrm{ml}$ and an equal volume of ethanol was added. The solution was precipitated overnight at $-20^{\circ} \mathrm{C}$, centrifuged $(1000 \mathrm{xg})$ and decanted. Both supernatant and precipitate were evaporated under vacuum and assayed for bioactivity using LLAs.

\section{Acid hydrolysis}

Acid hydrolysis of fractions was used to determine the monsaccharide constituents of the algal polysaccharides. Algal fractions $(\sim 200 \mathrm{mg})$ were refluxed 
in $5 \%$ hydrochloric acid (Fisher) overnight at $100^{\circ} \mathrm{C}$. Hydrolysed algal fractions and mono- or polysaccharide standards were chromatographed on silica gel TLC plates using methylene chloride:methanol (8:3) $\mathrm{v} / \mathrm{v}$ and developed with phenol sulphuric acid.

\section{Schöniger's oxygen flask method}

Sulphur analysis using this method was performed by Peter Borda of the Department of Chemistry, University of British Columbia using Schöniger's oxygen flask method (Hilp, 1988).

\section{Transmission Electron Microscopy of PVX}

Following up on work completed by Sano (1995), transmission electron microscopy (TEM) was used to evaluate the effects of fractions (crude extract, fraction A from $P$-1-frac.28, fraction B from $S e$-2-frac 1-2) from $F$. gardneri on PVX morphology and distribution. Preparation of treatment solutions was designed to reflect that of local lesion assays, therefore solutions of each extract $(10 \mu \mathrm{l} / \mu \mathrm{g})$ were prepared using LLA control solution (aqueous 5\% 2-methoxy ethanol). A $200 \mu$ l aliquot of each solution was mixed with $10 \mu \mathrm{l}$ of PVX $(1.15 \mathrm{mg} / \mathrm{ml})$, vortexed and allowed to incubate for 30 minutes. Electron microscopy grids (Ni 200) were prepared by applying $10 \mu \mathrm{l}$ of solution to the film surface for 1 minute. Solutions were then removed from grids using hardened filter paper (Whatman). Grids were then briefly treated with $10 \mu \mathrm{l}$ of $2 \%$ uranyl acetate (Canemco) in acetone and dried as before with hardened filter paper. Using a Zeiss 10C TEM (Germany), grids were viewed at magnifications between 31,500 and $50,000 \mathrm{x}$ 's.

\section{Polysaccharide Isolation}

The primary polysaccharides from $F$. gardneri were isolated according to modified methods of Mian and Percival (1973). Fresh plant material $(1.5 \mathrm{~kg})$ was 
collected from Towers Beach, Vancouver $\left(49^{\circ} 16^{\prime} \mathrm{N}, 123^{\circ} 15^{\prime} \mathrm{W}\right)$ in August 2001, washed, and ground fresh in liquid nitrogen using a mortar and pestle. Timing of this collection coincided with reported peak accumulation of carbohydrate reserves (Tuomi et al., 1989). The ground plant material was extracted twice with $6 \mathrm{~L}$ of ethanol to reduce the amount of phenolic compounds that could otherwise contaminate polysaccharide fractions. Ethanol (1) was decanted and plant material allowed to dry. From this, 230g (dry weight) was extracted by constant stirring with $3 \mathrm{~L}$ of $2 \%$ aqueous calcium chloride $\mathrm{BDH}$ Chemical Co.) for four hours at room temperature. This yielded a laminarin and "fucans" fraction (2). Residual plant material was collected by filtration and further extracted in $3 \mathrm{~L}$ of dilute hydrochloric acid (Fisher) at $70^{\circ} \mathrm{C}$ for 4 hours under constant stirring, during which time a $\mathrm{pH}$ of 2 was maintained by addition of further hydrochloric acid. This yielded a "fucans" fraction (3). A final extraction of the residual plant material was done with $3 \mathrm{~L} 3 \%$ sodium carbonate (MCB Reagents) heated to $50^{\circ} \mathrm{C}$ and stirred constantly for 9 hours. This yielded an alginate and "fucans" fraction (4). Each of the three aqueous fractions (2-4) was reduced to a volume of $500 \mathrm{ml}$ in vacuo at $40^{\circ} \mathrm{C}$. Crude polysaccharide fractions were further isolated by the addition of $1-1.5 \mathrm{~L}$ of ethanol. Precipitated polysaccharide was removed by filtration and washed with additional ethanol. 


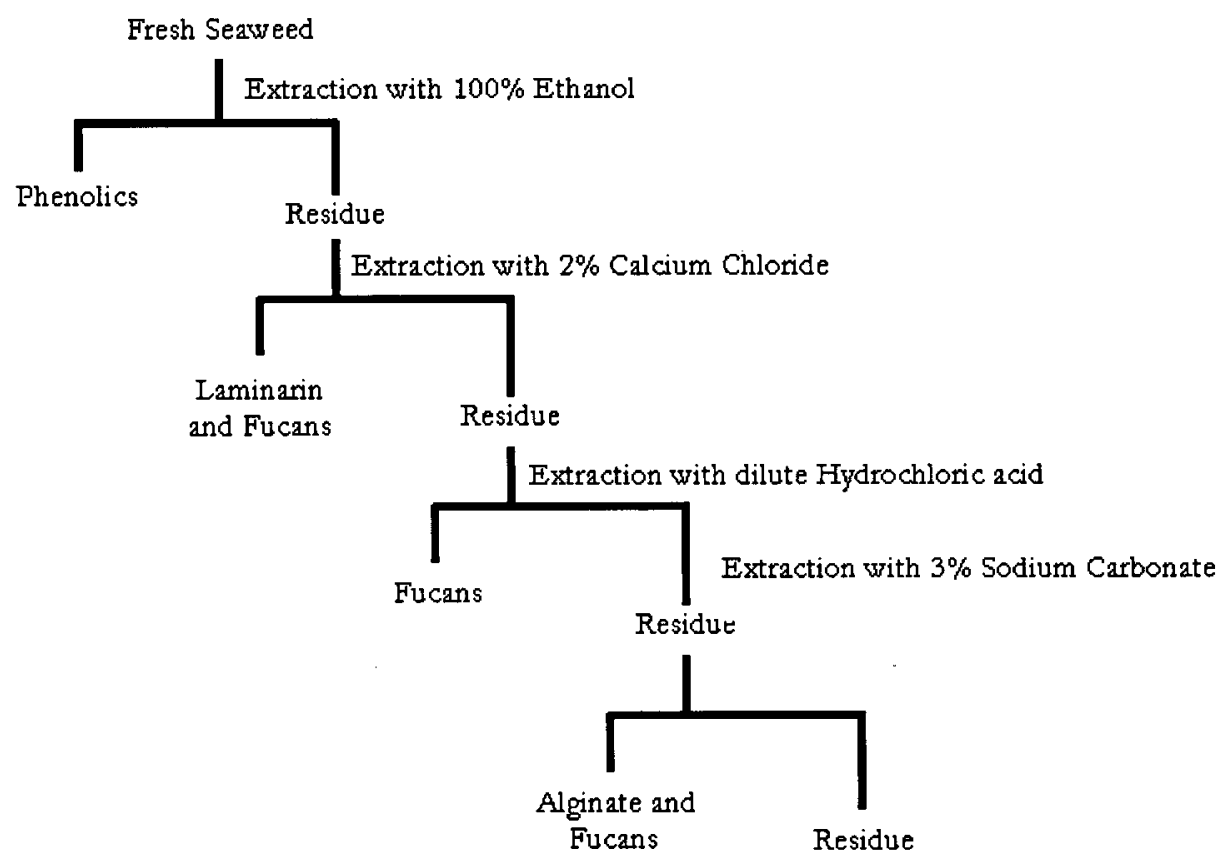

Figure 3.2: Flow diagram of serial polysaccharide extraction of Fucus gardneri (modified from Main and Percival, 1973).

Each of the three crude polysaccharide fractions was fractionated using Sephadex G-100 (Sigma) column gel filtration. Sephadex G-100 (68g) was prepared for chromatography by boiling in distilled deionized water for 2 hours. The slurry was poured to build three columns $(3 \times 25 \mathrm{~cm})$. Precipitates $(2.14 \mathrm{~g}, 3$. $13 \mathrm{~g}$ and $4.15 \mathrm{~g}$ ) from each fraction were dissolved in $125 \mathrm{ml}$ of water and applied to a column. Columns were eluted isocratically using distilled, deionized water. Fractions were collected, dried in vacuo, pooled based on TLC profile and assayed for bioactivity in LLAs. Once isolated, polysaccharide fractions were assayed for bioactivity and active fractions compared with purchased standards (fucoidan, alginate and lamanarin) using acid hydrolysis. Hydrolysis was performed by refluxing samples and standards individually in $100 \mathrm{ml} 10 \% \mathrm{HCl}$ $\mathrm{v} / \mathrm{v}$ for 3 hours, simple sugar residues generated were compared on cellulose TLC plates (EM Science) using water-saturated butanol as the solvent system. 
For comparison, eight commercial polysaccharide standards (soluble starch (Nutritional Biochemical Co.), dextran sulphate (Sigma), dextran (Sigma), agar (BDH Chemical Co.), chitosan (Sigma), sodium alginate (Matheson Coleman and Bell), laminarin (Fluka) and fucoidan (Fluka)) were tested for antiviral effect in LLAs at $10 \mu \mathrm{g} / \mu \mathrm{l}$. Alginate standard was tested over a concentration gradient $(33 \mu \mathrm{g} / \mu \mathrm{l}-0.01 \mu \mathrm{g} / \mu \mathrm{l})$ to evaluate the range of antiviral effect and any phytotoxicity. 


\section{Results}

\section{PRELIMINARY PHYTOCHEMISTRY}

Extraction of dry plant material over a time course yielded levels of bioactivity dependent on the polarity of the extraction solvent (Table 3.1). Determination of bioactivity in solvent aliquots taken over the time course clearly showed that compounds responsible for the antiviral effect were preferentially soluble in methanol.

Table 3.1: Percent inhibition of PVX infectivity in LLAs by extracts from two different solvent extractions over a time course.

\begin{tabular}{ccc}
\hline Infusion Time & $\begin{array}{c}\text { Hexanes- \% } \\
\text { Inhibition }\end{array}$ & $\begin{array}{c}\text { Methanol- \% } \\
\text { Inhibition }\end{array}$ \\
\hline 1 minute & $26.0 \pm 19.0$ & $100.0 \pm 0$ \\
$\mathbf{2 . 5}$ hours & $-21.6 \pm 9.4$ & $100.0 \pm 0$ \\
$\mathbf{2 6}$ hours & $46.0 \pm 16.4$ & $100.0 \pm 0$
\end{tabular}

Positive values refer to viral inhibition, negative values refer to viral stimulation and \pm refers to the standard error of the mean.

In both cases bioactivity from preparatory-TLC was found exclusively at the origin of TLC plates. Table 3.2 is a summary of the bioactivity found on the plates with band 1 being the origin and band 8 the top of the elution profile (Figure 3.3). Similarly results from the initial silica column chromatography (Si-1) showed that the silica retained much of the bioactivity (Table 3.3). Antiviral activity that did elute from the column came near the end of the profile (fractions 151-154) and was weak (42-69\%) regardless of concentration. Combinations of extracts tested did not show evidence of synergy between fractions. It should be noted that in these cases both preparatory-TLC and silica column chromatography used relatively non-polar solvent systems. 
Table 3.2: Percent bioactivity of compounds isolated from preparatory-TLC bands, with band one being the plate origin and band 8 the top of the elution profile.

\begin{tabular}{ccccc}
\hline Band & $\mathbf{1}$ (origin) & $\mathbf{2}$ & $\mathbf{3}$ & $\mathbf{4}$ \\
\% PVX Inhibition & $100 \pm 0$ & $30.4 \pm 17.8$ & $-73.7 \pm 26.6$ & $-25.7 \pm 34.8$ \\
\hline \hline Band & $\mathbf{5}$ & $\mathbf{6}$ & $\mathbf{7}$ & $\mathbf{8}$ (top) \\
\% PVX Inhibition & $-49.7 \pm 16.6$ & $13.5 \pm 13.2$ & $-54.8 \pm 24.5$ & $20.7 \pm 12.1$ \\
\hline \hline
\end{tabular}

Positive values refer to viral inhibition, negative values refer to viral stimulation and \pm refers to the standard error of the mean.

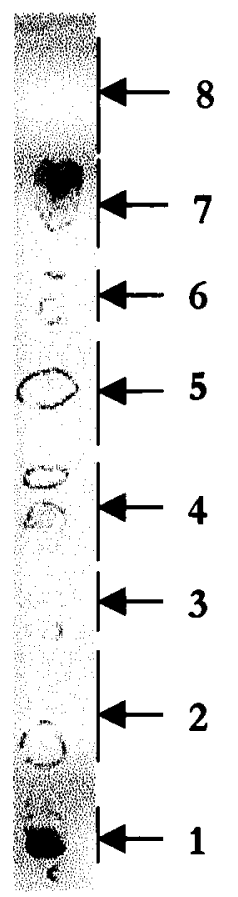

Figure 3.3: Silica preparatory thin-layer chromatogram of crude Fucus gardneri extract. Numbers 1-8 represent the banding pattern tested for bioactivity (Table 3.2). Solvent system chloroform:methanol (13:1). Plate was developed using vanillin-sulphuric acid reagent. 
Table 3.3: Percent inhibition of PVX infectivity in LLAs by groups of fractions collected from silica column chromatography $\left(S_{i-1}\right)$.

\begin{tabular}{|c|c|c|c|c|c|c|}
\hline Fractions & $1-14$ & $15-22$ & 23 & $24-39$ & $40-52$ & $53-83$ \\
\hline $\begin{array}{c}\text { \% PVX } \\
\text { Inhibition }\end{array}$ & $\begin{array}{l}-3.1 \\
\pm 8.3\end{array}$ & $\begin{array}{c}-3.6 \\
\pm 17.4\end{array}$ & $\begin{array}{l}-28.4 \\
\pm 42.6\end{array}$ & $\begin{array}{c}3.3 \\
\pm 6.0\end{array}$ & $\begin{array}{l}-16.0 \\
\pm 7.0\end{array}$ & $\begin{array}{l}-42.6 \\
\pm 55.3\end{array}$ \\
\hline Fractions & $84-143$ & 144-150 & 151 & 152 & 153 & 154 \\
\hline $\begin{array}{c}\text { \% PVX } \\
\text { Inhibition }\end{array}$ & $\begin{array}{l}-28.7 \\
\pm 27.9\end{array}$ & $\begin{array}{l}-44.9 \\
\pm 19.0\end{array}$ & $\begin{array}{r}68.6 \\
\pm 3.2\end{array}$ & $\begin{array}{c}46.0 \\
\pm 23.2\end{array}$ & $\begin{array}{c}42.7 \\
\pm 12.4\end{array}$ & $\begin{array}{c}69.1 \\
\pm 15.7\end{array}$ \\
\hline
\end{tabular}

Positive values refer to viral inhibition, negative values refer to viral stimulation and \pm refers to the standard error of the mean.

Thin-layer chromatography and LLAs of autoclaved crude extract found no changes with bioactivity remaining at $100 \%$ (Table 3.4 , TLC not shown). Methylation of the crude extract yielded a dramatic change to both the biological activity and TLC profile (Table 3.4, Figure 3.4). Bioactivity of crude extract was reduced from $100 \%$ to less than zero. Controls showed that activity was soluble

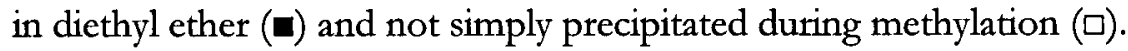

Table 3.4: Percent inhibition of PVX infectivity of fractions collected before and after heat treatment and diazo-methylation of crude $F$. gardneri determined using LLAs.

\begin{tabular}{ll}
\hline Fractions & \% PVX Inhibition \\
\hline Autoclaved crude $F$. gardneri & $100 \pm 0$ \\
Methylated crude $F$. gardneri & $-46.2 \pm 47.2$ \\
Non-methylated crude $F$. gardneri & $100 \pm 0$ \\
Crude in diethyl ether $(\square)$ & $100 \pm 0$ \\
Methylation precipitate $(\square)$ & $23.9 \pm 8.0$
\end{tabular}

Positive values refer to viral inhibition, negative values refer to viral stimulation and \pm refers to the standard error of the mean. 


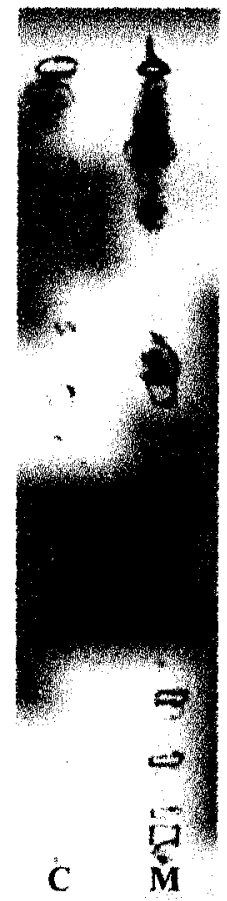

Figure 3.4: Silica thin-layer chromatogram of crude (c) and methylated (m) Fucus gardneri extracts (Table 3.4). As this comparison demonstrates, methylation of the crude extract resulted in the generation of new compounds. Solvent system hexane:ethyl acetate (3:7). Vanillin-sulphuric acid reagent used to develop plate.

Amberlite XAD-2 column chromatography (A-1) of the crude extract yielded thirteen fractions. These were grouped according to TLC profile into four groups that correlated with changes in elution solvents (Table 3.5). Bioactivity as determined by LLAs was found primarily in the ammonium hydroxide fraction (pH 11). 
Table 3.5: Percent inhibition of PVX infectivity in LLAs of fractions collected from Amberlite XAD-2 column chromatography $(A-1)$.

\begin{tabular}{ccc}
\hline Fractions & Elution Solvent & \% PVX Inhibition \\
\hline $\mathbf{1 - 4}$ & Water & $7.1 \pm 10.8$ \\
$\mathbf{5 - 8}$ & Water:Acetonitrile (75:25) & $52.6 \pm 18.0$ \\
$\mathbf{9 - 1 2}$ & Water:Acetonitrile (50:50) & $46.6 \pm 4.8$ \\
$\mathbf{1 3}$ & 3N Ammonium hydroxide & $96.9 \pm 2.1$
\end{tabular}

Positive values refer to viral inhibition, negative values refer to viral stimulation and \pm refers to the standard error of the mean.

\section{PRELIMINARY EVIDENCE SUgGESTING TWO ACTIVE COMPOUNDS}

Dialysis was used to fractionate the crude extract early in the phytochemical analysis of $F$. gardneri. Over a period of 72 hours with regular changes in the solution, dialysis reached equilbrium. In the process, bioactive compounds were found both inside and outside the dialysis membrane. Sephadex LH-20 chromatography $(S e-1)$ of an $F$. gardneri fraction yielded 54 fractions. These were clustered into five groups based on TLC profiles and when assayed for bioactivity yielded two distinct groups of fractions with antiviral activities of 73\% (frac.4-7) and 95\% (frac. 13-35) (Table 3.6).

Table 3.6: Percent inhibition of PVX infectivity of fractions collected from Sephadex LH-20 column chromatography $\left(S_{e-1}\right)$.

\begin{tabular}{cc}
\hline Fractions & \% PVX Inhibition \\
\hline $\mathbf{1 - 3}$ & $25.0 \pm 23.4$ \\
$\mathbf{4 - 7}$ & $73.3 \pm 5.6$ \\
$\mathbf{8 - 1 2}$ & $19.5 \pm 24.7$ \\
$\mathbf{1 3 - 3 5}$ & $95.3 \pm 1.0$ \\
$\mathbf{3 6 - 5 4}$ & $26.6 \pm 15.5$ \\
\hline
\end{tabular}




\section{PhyTOCHEMISTRY}

Extraction of $10 \mathrm{~kg}$ of $F$. gardneri yielded $145 \mathrm{~g}$ of crude extract that was verified by LLA to completely inhibit PVX infectivity. Liquid partitioning of this crude extract yielded hexane $(26 \mathrm{~g})$, ethyl acetate $(12.5 \mathrm{~g})$, butanol $(64 \mathrm{~g})$ and water (42g) fractions that were also found to be all $100 \%$ antiviral. The ethyl acetate fraction was further fractionated using silica column chromatography (Si-2) yielding 100\% bioactivity from fractions 53-78 (acetone:methanol 95:5 - 0:100) $\mathrm{v} / \mathrm{v}$ (Table 3.7).

Table 3.7: Percent inhibition of PVX infectivity from silica column chromatography (Si-2) of the ethyl acetate fraction from liquid partitioning of crude $F$. gardneri extract.

\begin{tabular}{cccc}
\hline Fractions & \% PVX Inhibition & Fractions & \% PVX Inhibition \\
\hline $\mathbf{1 - 4}$ & $47.6 \pm 7.3$ & $\mathbf{3 2 - 3 8}$ & $33.8 \pm 14.0$ \\
$\mathbf{5 - 8}$ & $2.8 \pm 4.1$ & $\mathbf{3 9 - 5 2}$ & $-1.9 \pm 42.6$ \\
$\mathbf{9 - 1 2}$ & $-2.8 \pm 46.3$ & $\mathbf{5 3 - 5 9}$ & $100 \pm 0$ \\
$\mathbf{1 3 - 1 5}$ & $0.3 \pm 23.6$ & $\mathbf{6 0 - 6 3}$ & $100 \pm 0$ \\
$\mathbf{1 6 - 2 0}$ & $56.8 \pm 8.7$ & $\mathbf{6 4 - 7 1}$ & $100 \pm 0$ \\
$\mathbf{2 1 - 2 5}$ & $11.5 \pm 36$ & $\mathbf{7 2 - 7 3}$ & $100 \pm 0$ \\
$\mathbf{2 6 - 3 1}$ & $26.2 \pm 13.6$ & $\mathbf{7 4 - 7 8}$ & $100 \pm 0$
\end{tabular}

Positive values refer to viral inhibition, negative values refer to viral stimulation and \pm refers to the standard error of the mean.

Sephadex LH-20 column chromatography ( $S e-2)$ of active fractions (5378 - total $3 \mathrm{~g}$ ) obtained by silica chromatography (Si-2) yielded nine fractions averaging $240 \mathrm{ml}$ each (Table 3.8). Local lesion assays of these fractions revealed two distinct groups of bioactivity. Fractions 6-9 (2.4g) showed considerable bioactivity and fractions 1 and $2(0.1 \mathrm{~g})$ were completely antiviral. These two groups of antiviral compounds will be referred to as Fraction A and Fraction B respectively (Table 3.8 ). 
Table 3.8: Percent inhibition of PVX infectivity in LLAs by fractions collected from Sephadex LH-20 column chromatography (Se-2) of silica column (Si-2) fractions (53-78).

\begin{tabular}{cccl}
\hline Fractions & Solvent & \% PVX Inhibition & Reference \\
\hline $\mathbf{1}$ & Methanol & $100 \pm 0$ & FRACTION B \\
$\mathbf{2}$ & Methanol & $99.9 \pm 0.1$ & \\
$\mathbf{3}$ & Methanol & $81.4 \pm 4.0$ & \\
$\mathbf{4}$ & Methanol & $-3.1 \pm 13.3$ & \\
$\mathbf{5}$ & Methanol & $\mathbf{6 5 . 5} \pm 4.3$ & \\
$\mathbf{6 - 7}$ & Methanol & $87 \pm 4.4$ & FRACTION A \\
$\mathbf{8 - 9}$ & Acetone & $100 \pm 0$ & \\
\hline
\end{tabular}

Positive values refer to viral inhibition, negative values refer to viral stimulation and \pm refers to the standard error of the mean.

\section{CharaCterization}

\section{Fraction A}

In dialysis, bioactive compounds in fraction A passed through the cellulose membrane and into the surrounding distilled water. Thin-layer chromatography of fraction A yielded several bands that individually were reactive to Folin-Ciocalteu (phenols) and Ninhydrin (amino groups) and reacted slightly with phenol-sulphuric acid (carbohydrates) and Dragendorff's (alkaloids) reagents. At this point it was not clear which band was responsible for bioactivity of fraction $\mathrm{A}$.

\section{Betaines}

Amberlite IR-120 chromatography $(A-2)$ was used to address the possibility of algal betaines exerting an antiviral effect (Table 3.9). Chromatography of crude extract yielded water and ammonium hydroxide fractions. The latter fraction was partitioned with butanol, producing aqueous and butanol fractions. Spray reagents confirmed that the aqueous ammonia fraction was positive for both amino and quaternary nitrogen moieties. 
Table 3.9: Percent inhibition of PVX infectivity in LLAs by fractions collected from Amberlite IR-120 column chromatography (A-2).

\begin{tabular}{lc}
\hline \multicolumn{1}{c}{ Fractions } & \% PVX Inhibition \\
\hline Water Fraction & $98.1 \pm 2.0$ \\
Ammonia fraction - Aqueous* & $89.0 \pm 14.9$ \\
Ammonia fraction - Butanol & $16.5 \pm 16.3$ \\
\hline
\end{tabular}

* Positive reaction with dragendorff's reagent.

Positive values refer to viral inhibition, \pm refers to the standard error of the mean.

\section{Peptides}

Following up on the potential of amino-based compounds contributing to the antiviral effect, acid urea gel electrophoresis and SDS-PAGE were performed to look for anti-viral peptides. Acid urea gel electrophoresis, designed to isolate cationic peptides, did not reveal any such molecules (image of gel not included). Likewise SDS-PAGE, which screens for total protein, did not find discrete banding; however staining with Coomassie blue indicated the presence peptide-containing compounds in material from fraction A (Figure 3.5). The tailing portion of the electrophoresis profile was dyed, while the region below the leading edge fluoresced white under short-wave ultraviolet light. 


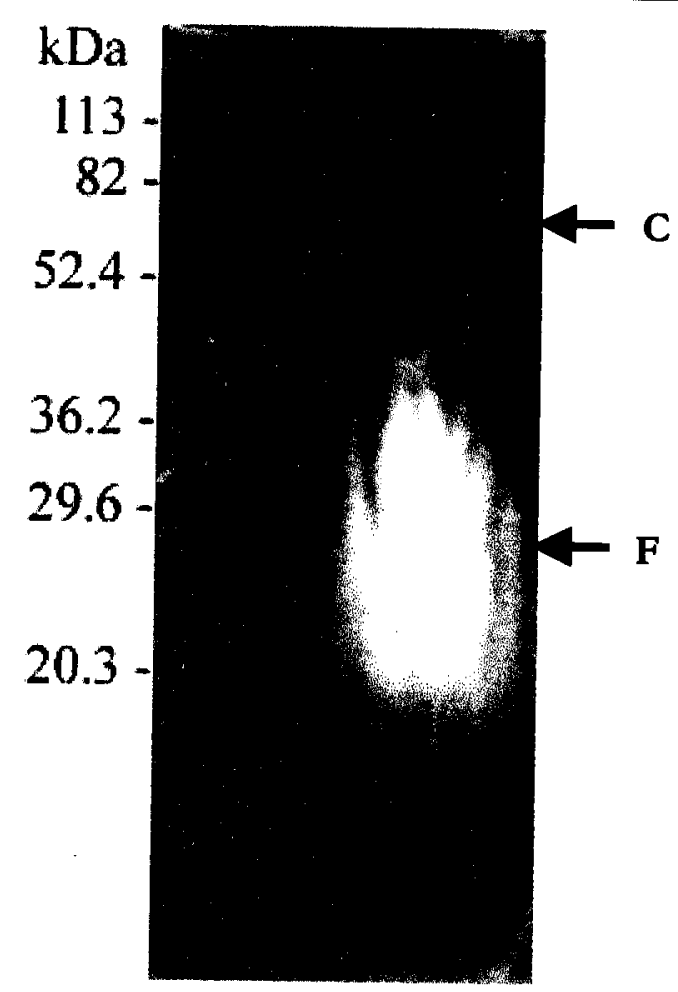

Figure 3.5: Fluorescence image of electrophoresis of fraction A in SDS-PAGE. Left lane contains protein molecular weight standards. Right lane contains fraction A: Dark Coomassie blue stained tail (Coomassie is specific for basic and aromatic amino acids) (C); White UV fluorescence $(\mathbf{F})$.

\section{Phenolic compounds}

To evaluate if antiviral activity was due to a phenolic compound, one fraction from group A was run through polyamide mini-columns. Activity was considerably reduced from $92.2 \%$ to $39 \%$ viral inhibition. Using appropriate spray reagents and TLC solvents, phloroglucinol, a common algal phenolic compound, was found to be present in active, crude and semi-pure fractions of $F$. gardneri. However, LLAs of phloroglucinol found no antiviral effect $(4.5 \%$ stimulation).

Building on the results of polyamide mini-columns and in an attempt to resolve remaining difficulties with purity of active fractions, fraction $A$ was applied to a large polyamide column $(P-I)$. Polyamide chromatography of fraction A led to significant increases in purity in two ways. Firstly, by briefly 
boiling the desiccated fraction in water, compounds responsible for bioactivity became soluble $(2.5 \mathrm{~g})$ while a considerable amount of material remained insoluble as a red precipitate. This aqueous solution was verified to be $100 \%$ antiviral and was run through the column yielding 28 fractions emerging in several clusters of activity (Table 3.10). Interestingly bioactivity eluted in three distinct groups. Thinlayer chromatography of eluted fractions found fraction 28 (99.3\% inhibition) to be particularly pure. Thin-layer chromatography of this fraction strongly indicated both carbohydrate and amino compounds (ninhydrin positive) in the principal band.

Table 3.10: Percent inhibition of PVX infectivity in LLAs from fractions collected from Polyamide column chromatography $(P-I)$ of fraction A of Sephedex LH-20 chromatography (Se-2).

\begin{tabular}{ccc}
\hline Fractions & $\begin{array}{c}\text { Elution Solvents } \\
\text { Applied in Series }\end{array}$ & $\begin{array}{c}\% \text { PVX } \\
\text { Inhibition }\end{array}$ \\
\hline $\mathbf{1 - 4}$ & Water & $52.9 \pm 20.7$ \\
$\mathbf{5 - 6}$ & Water & $60.1 \pm 20.0$ \\
$\mathbf{7 - 1 4}$ & Water & $53.1 \pm 17.9$ \\
$\mathbf{1 5}$ & Water:Methanol (50:50) & $59.8 \pm 18.8$ \\
$\mathbf{1 6 - 1 9}$ & Water:Methanol (50:50) & $93.3 \pm 5.6$ \\
$\mathbf{2 0 - 2 1}$ & Methanol & $58.6 \pm 23.0$ \\
$\mathbf{2 2}$ & Methanol & $86.7 \pm 29.6$ \\
$\mathbf{2 3 - 2 4}$ & Methanol & $100 \pm 0$ \\
$\mathbf{2 5 - 2 6}$ & Acetone & $100 \pm 0$ \\
$\mathbf{2 7}$ & Acetone & $2.4 \pm 18.9$ \\
$\mathbf{2 8}$ & Acetone & $99.3 \pm 0.6$ \\
\hline Positive values refer to viral inhibition, \pm refers to the standard error of the mean.
\end{tabular}

\section{Fraction B}

Dialysis of fraction B from Sephadex LH-20 chromatography (Se-2) found that bioactivity remained within the cellulose membrane. Using TLC, this same fraction reacted positively with the phenol-sulphuric acid reagent (carbohydrates) but not Folin-Ciocalteu (phenols) or Dragendorffs (alkaloids) spray reagents. The presence of carbohydrates was confirmed using Dubois' 
(1956) method, with both fraction B and agar (positive standard) solutions developing a distinct yellow to brown color.

Ethanol precipitation of the Sephadex LH-20 fraction B yielded a cream colored precipitate. Acid hydrolysis of this precipitate established it as crude polysaccharide (Figure 3.6). Thin-layer chromatography of hydrolysate, yielded four sugar residues one of which was glucose. Using Schöniger's oxygen flask method, Peter Borda of the Department of Chemistry (University of British Columbia) found sulphur to contribute $1.5 \%$ dry weight to the precipitate. Bioactivity of this precipitate was $100 \%$ while acid hydrolysed extract had no antiviral effect.

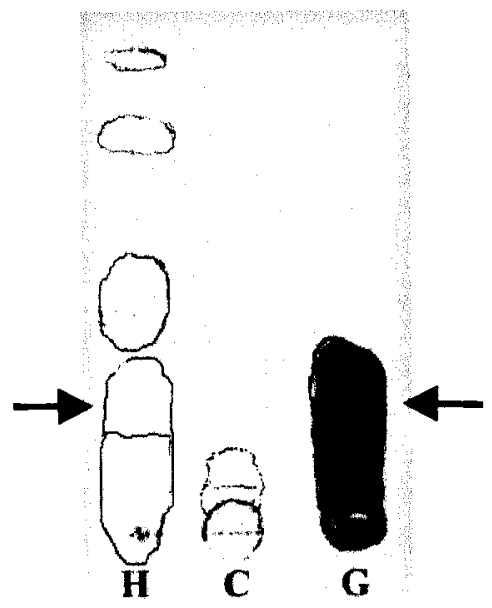

Figure 3.6: Thin-layer chromatogram of acid hydrolysed fraction $B(\mathbf{H})$, crude fraction B (C) and glucose sugar standard (G). Arrows indicate glucose bands in standard and hydrolysed sample. Solvent system methylene chloride:methanol (8:3). TLC plate developed with phenol-sulphuric acid spray reagent specific for carbohydrates.

Transmission electron microscopy showed that PVX particles in the control appeared randomly arranged and interwoven, whereas particles exposed to the polysaccharide fraction (B) were almost exclusively aggregated in needlelike rafts (Figure 3.7). As a comparison, virus particles were also exposed to a strongly antiviral fraction from fraction A. Some aggregation of virus particles was observed; however, for the most part this treatment was comparable to 
control. Images of virus treated with crude extract were obscured by undissolved material, thus are not included.
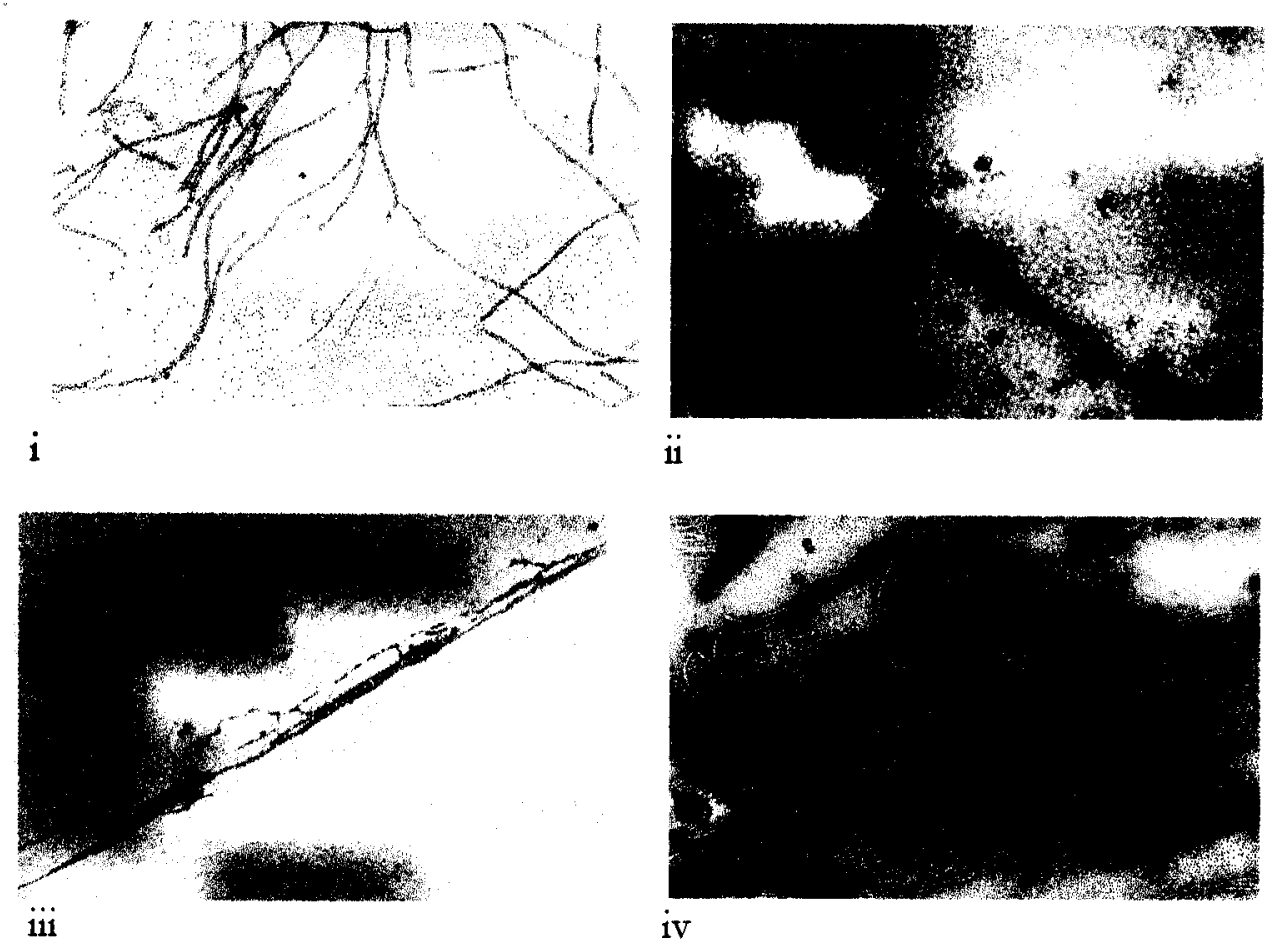

iii

iv

Figure 3.7: Transmission electron microscopy images of PVX particles after incubation in the following solutions: (i) negative control, (ii) polysaccharide treatment (fraction B), (iii \& iv) alginate. Virus in negative control appears randomly arrange and non-linear, while virus treated with fraction $B$ containing polysaccharide aggregated into needle-like rafts (iii) representative of most aggregates in alginate solution (iv) massive aggregation observed in several alginate preparations. Magnification x 31500 .

Isolation of the specific bioactive polysaccharide (Mian and Percival, 1973) resulted in four crude fractions: 1. ethanol extraction(3.55g), 2. calcium chloride extraction $(9.49 \mathrm{~g})$, 3. hydrochloric acid extraction(3.96g) and 4. sodium carbonate extraction(79.1g). All four crude fractions had strong antiviral effect in LLAs (Table 3.11). Crude polysaccharide fractions (2, $3 \& 4$ ) were fractionated using Sephadex G-100 chromatography yielding 8, 6 and 9 fractions respectively. Fractions from each Sephadex G-100 column were tested using LLAs. Only fractions from hydrochloric acid (3) and sodium carbonate (4) extractions were 
found to completely inhibit PVX infectivity. These active, purified polysaccharides were hydrolysed and compared to simple sugars and standard laminarin, fucoidan and alginate using TLC. Results from chromatography of hydrolysed active fractions (Figure 3.8) and bioassays of commercial standards (Table 3.12) combine to implicate alginate as the source of bioactivity in fraction B. Alginate completely inhibited PVX infectivity at concentrations of $1 \mu \mathrm{g} / \mu \mathrm{l}$, $10 \mu \mathrm{g} / \mu \mathrm{l}$ and $33 \mu \mathrm{g} / \mu \mathrm{l}$. Laminarin was the only other polysaccharide standard to show inhibition of PVX infectivity; however, chromatography of hydrolysates from the most antiviral polysaccharide fractions isolated did not show evidence of glucose (monomer of laminarin).

Table 3.11: Percent inhibition of PVX infectivity of crude polysaccharide fractions collected in a serial extraction of $F$. gardneri.

\begin{tabular}{lc}
\hline \multicolumn{1}{c}{ Fraction } & \% PVX Inhibition \\
\hline Ethanol extraction & $99.4 \pm 0.59$ \\
Calcium chloride extraction & $98.6 \pm 0.80$ \\
Hydrochloric acid extraction & $84.1 \pm 14.76$ \\
Sodium carbonate extraction & $85.7 \pm 2.08$ \\
\hline Positive values refer to viral inhibition, \pm refers to the standard \\
error of the mean.
\end{tabular}

Table 3.12: Percent inhibition of PVX infectivity of commercially prepared polysaccharides.

\begin{tabular}{lllc}
\hline Polysaccharide & $\begin{array}{c}\text { \% PVX } \\
\text { Inhibition }\end{array}$ & Polysaccharide & $\begin{array}{c}\text { \% PVX } \\
\text { Inhibition }\end{array}$ \\
\hline Soluble starch & $-42.9 \pm 38.8$ & Chitosan & $-63.2 \pm 44.7$ \\
Dextran sulphate & $-35.4 \pm 47.2$ & Alginate & $95.2 \pm 3.9$ \\
Dextran & $-36.8 \pm 30.5$ & Laminarin & $56.6 \pm 25.1$ \\
Agar & $-57.4 \pm 10.4$ & Fucoidan & $-71.9 \pm 32.9$ \\
\hline \multicolumn{2}{l}{ Positive values refer to inhibition of infectivity; } & Negative values refer to stimulation of infectivity. \\
土 refers to the standard error of the mean.
\end{tabular}




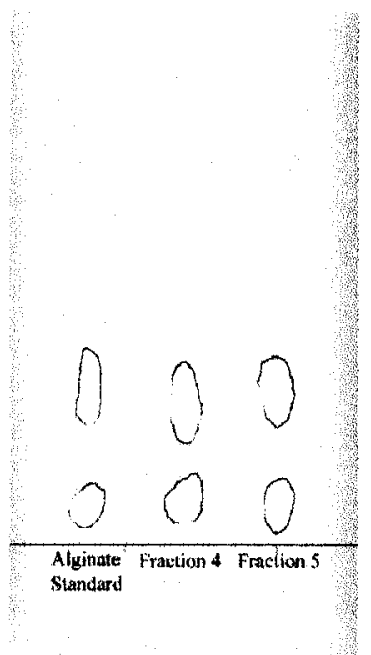

Figure 3.8: Thin-layer chromatography of hydrolysed alginate standard and active fractions from Sephadex G-100 chromatography. Chromatography profiles match. Using an alginate standard for comparison, the presence of alginate in active fractions (100\%) of hydrochloric acid (4) and sodium carbonate (5) extractions was confirmed. Solvent system: water saturated butanol and 1 drop formic acid. TLC plate sprayed with phenol-sulphuric acid. 


\section{Discussion}

\section{Preliminary Characterization}

A comparison between extraction of the plant material over a 24-hour period with either hexane or methanol provided the first evidence that antiviral bioactive molecules from $F$. gardneri were polar (Table 3.1). The polar nature of the active material was confirmed using silica preparatory-TLC and column chromatography $\left(S_{i-1}\right)$. During these fractionations, elution of the antiviral agents was reduced by interaction with the polar silicate substrate. This effect was illustrated in the case of preparatory-TLC by bioactivity being found only at the origin of the plate, and in column chromatography by bioactivity eluting late from the column and with only marginal effect (Tables 3.2 and 3.3). These preliminary findings which found the bioactivity to be polar in nature, tended to rule out nonpolar compounds, like steroids or pigments, as being the source of antiviral activity.

Exposure of the crude extract to methylation, heat and alkali provided other valuable information. Effects of heat and alkali were chance observations made in association with other experiments. When autoclaved in preparation for tissue culture, samples of the crude extract remained 100\% antiviral and no obvious changes in the extract's TLC profile were observed (Table 3.4, TLC not shown). Chromatography of extracts on Amberlite XAD-2 and IR-120 ( $A-1 \& A$ 2) provided interesting results because final elutions used $3 \mathrm{M}$ ammonium hydroxide. As with exposure to heat, in both cases bioactivity remained intact following exposure to $\mathrm{pH} 11$ (Tables 3.5 and 3.9). It is difficult to make specific conclusions from these observations. The function of the active molecules appeared to be unchanged by heat and alkali; however, without further characterization it was not possible to rule out specific classes of molecules as possible sources of bioactivity. 
Diazomethylation helped me to deal with the highly polar nature of the bioactive compounds. By replacing hydroxyl groups with methyl groups, polar extracts were made more amenable to fractionation. Once purified, active compounds could be demethylated and compounds identified. Thin-layer chromatography and local lesion bioassays were used to gauge the effect of methylation on bioactivity and in both cases an obvious change in the properties of the crude extract was observed (Table 3.4 and Figure 3.4). Thin-layer chromatography profiles showed that there were twice as many bands in the methylated extracts than in the non-methylated material. This can be attributed to the generation of new compounds by methylation. Even more dramatic was the complete loss of bioactivity in methylated crude extracts. The knowledge that hydroxyl substituents are targeted during methylation hints at their importance in inhibition of PVX. This becomes important in understanding the mode of action of fraction B. Despite this success, methylation was later abandoned as a method of purification because of problems associated with demethylation.

\section{DISCOVERY OF TWO ACTIVE FRACTIONS}

In the development of a fractionation protocol, several forms of separation were attempted including dialysis and Sephadex LH-20 column chromatography. The first indication that bioactivity resided in more than one molecular source came during dialysis of the crude extract. Dialysis was performed until no further material passed through the membrane at 72 hours. Upon assaying the fractions, it was found that bioactivity was both retained and excluded by the membrane, suggesting that two different sized molecules were involved in the antiviral effect. Likewise, fractionation of extracts with Sephadex LH-20 column chromatography resulted in two active fractions of different relative molecular weight (Table 3.6). Upon realization that bioactivity was the result of more than one compound, the focus changed to scaling up extraction and isolation protocols. 


\section{Phytochemistry}

Large-scale extraction and partitioning yielded hexane, ethyl acetate, butanol and water fractions, all of which were found to be completely antiviral. Finding bioactivity in non-polar fractions was a little surprising; and it seemed likely to be the result of over-extraction (recall Table 3.1). Nonetheless, the ethyl acetate fraction was chosen as a focus in hopes of targeting antiviral compounds of more moderate polarity. Silica column chromatography (Si-2) of the ethyl acetate fraction, as in the $S i-1$ column, yielded bioactive compounds late in the elution profile (Table 3.7). Aside from being completely antiviral, these fractions all shared a deep red and highly polar compound. This red compound was associated with most, but not all, of the strongly active fractions produced throughout this study. Several attempts to isolate this compound using thin-layer and column chromatography unfortunately failed to separate it from similarly polar compounds.

The active fractions from silica chromatography $(\mathrm{Si}-2)$ were pooled and further fractionated using Sephadex LH-20 column chromatography (Se-2; Table 3.8). As before, two groups of active fractions eluted from the column: fraction $A$ (low molecular weight) and fraction B (high molecular weight), from this point on these fractions were evaluated separately. 


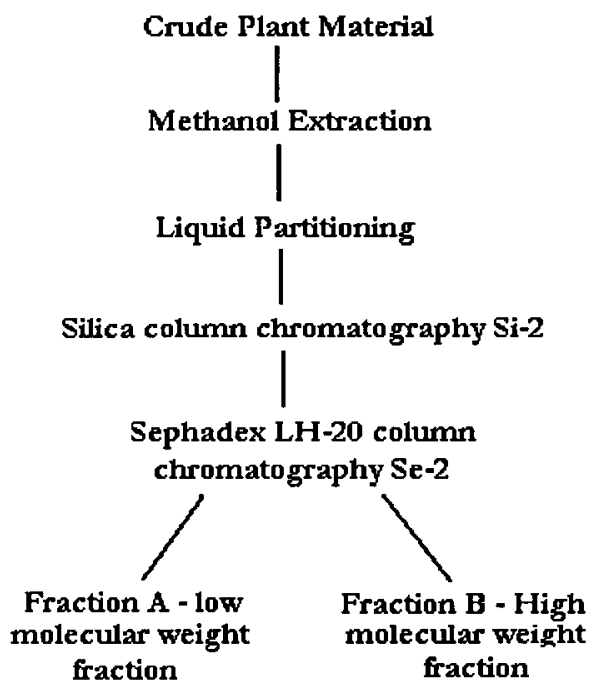

Figure 3.9: Flow diagram of methods used leading to the isolation of fraction $A$ and B from Sephadex LH-20 column chromatography (Se-2).

\section{Characterization of Fraction A}

With the separation of fractions $A$ and $B$, the focus of the project changed to isolation and identification of their active constituents. Dialysis of fraction A established bioactivity to be water-soluble and small enough to pass through dialysis tubing (M.W. cut-off 12,000). Thin-layer chromatography identified phenolic, amino groups and possibly carbohydrates and quaternary nitrogen in this fraction; however, from this little else can be specified. Bioactivity could originate from any of the earlier mentioned classes of molecules; thus the role of each in bioactivity was addressed individually.

\section{Polysaccharides}

Using a protocol to dereplicate extracts for sulphated polysaccharides, fraction A was precipitated with ethanol. Upon the addition of ethanol to fraction A no precipitate resulted suggesting that polysaccharides were not present. The 
positive reaction for carbohydrates observed in TLC may have been in response to glucoside components of proteins or tannins.

\section{Betaines}

Following up on the suspicion that betaines may contribute to the antiPVX effect of $F$. gardneri, isolation methodology from Blunden and Gordon (1986) was performed. To separate betaines from other algal metabolites, the extract was fractionated using Amberlite IR-120 column chromatography (A-2). According to Blunden and Gordon (1986), betaines would elute into the ammonia fraction. This "betaine" fraction, which was verified as containing both quaternary ammonium and amino groups, was found to reduce viral infectivity (Table 3.9). Interestingly, the ninhydrin reaction in this fraction was unique in that the color change was yellow, rather than purple suggesting an n-terminal proline. Although activity was found in the "betaine" fraction, chromatography achieved little purification and thus little confidence that betaines were in fact responsible for bioactivity.

\section{Peptides and Lectins}

With the finding that constituents of fraction A contained amino groups and the assistance of Dr. R.E.W. Hancock (Department of Microbiology, UBC), extracts of $F$. gardneri were evaluated for bioactive peptides. Natural peptides are known to have many therapeutic roles (Osusky et al. 2000; Zhang et al., 2000), including the antiviral cyanovirin-N from Nostoc ellipsosporum (Boyd et al., 1997). Acid-urea gel electrophoresis, which is specific for cationic peptides, was the first method used to isolate peptides. This method however did not yield any cationic peptides. Isolation of the total protein content of fraction A was then attempted using SDS-PAGE. Although this method was not successful in that discrete bands were not produced, some separation was achieved including one fraction that was positively stained by Coomassie blue (Figure 3.5). Coomassie blue is specific for basic and aromatic amino acids and therefore may indicate the 
presence of peptides. The molecular weight standards indicate that this region of the gel contains compounds with molecular weights larger than what would be expected for small peptides. Consequently it does not appear that such compounds are involved, however the diffuse and tailing nature of the stained region is consistent with the electrophoresis of glyco-proteins (I.E.P. Taylor personal communication). The contents of this band were sent for amino acid analysis; however, due to interruption of analytical services at both the University of British Columbia and the University of Victoria follow-up work on this fraction has not been completed.

\section{Phenolics}

Work focusing on phenolic compounds from $F$. gardneri has been the most conclusive of the characterization completed on fraction A. The role of phenolic compounds in bioactivity was confirmed by their selective removal using polyamide minicolumns. When run through polyamide, bioactivity from fraction A was dramatically reduced, indicating a role for polyphenols in antiviral activity. This finding was corroborated using Amberlite XAD-2 column chromatography $(A-1)$, which allowed for the isolation of phenolic compounds (Table 3.5). In this case, bioactivity was concentrated in the ammonium fraction, which according to Beress et al. (1993), contains phenolics, particularly phlorotannins. Considering the abundance of phenolic compounds, especially those based on phloroglucinol, in $F$. gardneri these findings are not too surprising. Thin-layer chromatography with a phloroglucinol standard confirmed its presence in crude extracts; however, when assayed for bioactivity phloroglucinol (4.5\% stimulation) itself was found to have no effect on PVX. It is likely that polymers of phloroglucinol are responsible for such bioactivity. Phenolic compounds from $F$. vesiculosus as well as other marine algae have been found inhibitory to HIV (Beress et al. 1993; Moen and Clark 1993), HSV-1 and Sindbis virus (Hudson et al., 1999a,b). 
Full size polyamide column chromatography $(P-1)$ was used in an attempt to isolate active phenolic constituents from fraction A. Preparation of fraction A for chromatography involved experimenting with brief boiling to solublize the material. While the bioactive components dissolved as a colorless solution, the deep red material that could not previously be separated (pg. 101) remained insoluble. The aqueous fraction was then run through polyamide and yielded three groups of bioactive fractions (Table 3.10). Although the purity of active fractions had improved, none consisted of a single compound and crystallization likewise did not yield active pure compounds. Of the three bioactive fractions, number 28 was the least contaminated and when tested the dominant band was strongly reactive to reagents for both amino groups and carbohydrates. This finding raises the possibility of a bioactive peptide; however, because of the problems with amino acid analysis further work on this fraction has remained unfinished. 


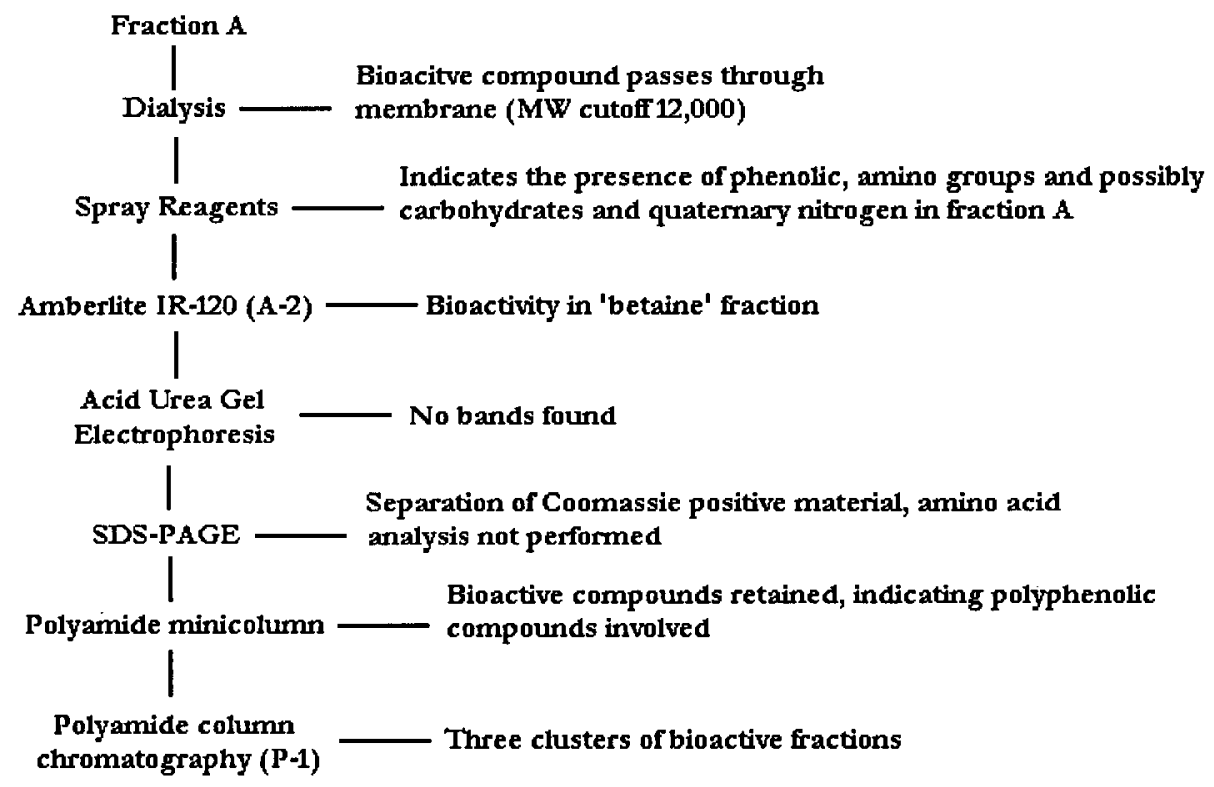

Figure 3.10: Summary of methods and results from the characterization of Fraction A.

\section{Fraction A summary}

Although progress was made in the fractionation of fraction $A$, the chemical origins of bioactivity in fraction A remain undefined. Although a portion of bioactivity can be clearly attributed to phenolic compounds, possible contribution from peptides, glyco-proteins or betaines cannot be ruled out. Bioactivity resulting from a phenolic compound can likely be attributed to phlorotannins simply because other abundance and previous findings (Beress et al., 1993). As the final polyamide column showed, there are at least two if not three active compounds in this fraction. It is this complexity, combined with what appears to be mixed biosynthetic origin (i.e.: glyco-protein) that explains the often non-specific and sometimes contradictory results observed. 


\section{FRACTION B}

Based on the separation results from Sephadex chromatography, it was assumed, because of the elution order, that the molecular weight of fraction $\mathrm{B}$ was greater than fraction $A$. This was confirmed by dialysis. Unlike fraction A, the bioactivity of fraction $B$ was retained by a semi-permeable membrane with a molecular weight cut-off of 12,000 daltons. An interesting correlation comes from Beress et al. (1993) who found that the most antiviral fraction of $F$. vesiculosus to be a polysaccharide fraction with a molecular weight between $10,000-20,000$ daltons.

Further characterization of this fraction suggested that the antiviral constituent was a sulphated polysaccharide. Ethanol precipitation, designed for the dereplication of sulphated polysaccharides, yielded an antiviral precipitate. When sprayed with phenol sulphuric acid, thin-layer chromatography of this precipitate was positive for carbohydrate. Using agar as a positive standard, this result was corroborated by a colorimetric phenol-sulphuric acid reaction in solution. Evidence of the precipitate being a polysaccharide was provided by acid hydrolysis. When sprayed with phenol-sulphuric acid, chromatography of the acid hydrolysate clearly showed the generation of 4 sugars, one of which was glucose (Figure 3.6). Glucose is one of the most common constituents of algal polysaccharides, being found in cellulose and laminarin, and is liberated along with other simple sugars during hydrolysis of glycosidic bonds. Evidence that the polysaccharide may be sulphated came from elemental analysis, which reported fraction $\mathrm{B}$ to contain $1.5 \%$ sulphur by dry weight. Several previous antiviral studies have found that sulphated polysaccharides act against both plant and animal viruses (Gonzalez et al., 1987; Nakashima et al., 1987; Baba et al., 1988, Sano, 1995). Fucus gardneri contains sulphated polysaccharides, the most abundant being fucoidan and sulphated hexuronoxylofucans (Painter, 1983). 
In work with tobacco mosaic virus, Sano (1995) found the sulphated polysaccharides chondroitin sulphate $C$ and A strongly inhibited viral infectivity in LLAs. Electron microscopy of an in vitro preparation of virus and chondroitin sulphates showed an aggregation of the virus particles, thus reducing the functional concentration of the virus in solution. To determine if fraction $\mathrm{B}$ had a similar effect on PVX, virus treated with this polysaccharide fraction was observed using transmission electron microscopy. Using the incubation protocol of LLAs, the effect of fraction B on PVX was clearly similar to the findings of Sano $(1995,1999)$. While control treatment left viruses randomly arranged and supple, viruses exposed to fraction B were aggregated in needle-like rafts (Figure 3.7).

Confident that one of the antiviral agents in $F$. gardneri was a polysaccharide, I attempted to make a positive identification of the glycan involved by using an extraction method specific to polysaccharides. Ethanol precipitation of aqueous algal extracts does yield polysaccharide, but the material is invariably a combination of alginic acid, fucoidan and protein (Percival and McDowell, 1967). Instead, I chose a method designed for the sequential extraction of laminarin, fucans and alginic acid (Table 3.11). The first extract, calcium chloride, which contains crude laminarin and fucans, was found to inhibit PVX in LLAs (Mian and Percival, 1973). Likewise, both the aqueous $\mathrm{HCl}$ extract containing crude fucans and the sodium carbonate extract containing crude alginate and fucans were found to inhibit viral infectivity.

Following Sephadex G-100 chromatography of these extracts, active fractions were hydrolyzed and compared to polysaccharide standards. Comparison of TLC profiles and evaluation of bioactivity identified alginate as the antiviral (95\%) polysaccharide (Table 3.12, Figure 3.8). Testing alginate over a range of concentrations $(33 \mu \mathrm{g} / \mu \mathrm{l}-0.01 \mu \mathrm{g} / \mu \mathrm{l})$, an antiviral effect was found to 
occur down to a concentration of $1 \mu \mathrm{g} / \mu \mathrm{l}$ with no indication of toxicity at any concentration. Referring back to work done on $F$. vesiculosus, a non-sulphated alginate fraction was also found to be antiviral against HIV (Beress et al., 1993). Laminarin likely also contributed to the overall bioactivity observed in fraction B; however, bioactivity of laminarin standards was marginal and TLC of hydrolysates did not identify this polysaccharide in the most potent fractions.

Although earlier evidence in this study implicated fucoidan as a likely candidate for antiviral activity in fraction B, it appears that alginic acid and fucoidan were co-isolated in Sephadex LH-20 chromatography. Fucoidan standard was tested in LLAs and was found to actually stimulate PVX infectivity (Table 3.12). It is also important to note that anti-viral activity of polysaccharides is not necessarily widespread. Of the eight commercial polysaccharides tested for antiviral activity against PVX, six actually stimulated PVX infectivity and only alginate showed any considerable bioactivity (Table 3.12).

Furthermore, recent work by Sano (1999) has also identified commercial sodium alginates to be antiviral against tobacco mosaic virus in LLAs on Nicotiana tabacum. As with fraction B in this study and chondroitin sulphate A and C (Sano, 1995), alginate was found to cause aggregation of virus particles into needle-like precipitates. This more recent work helped to elucidate the antiviral mode of action of these polysaccharides. Not only does aggregation reduce the functional concentration of the virus, thus reducing the frequency of infection, but it may prevent penetration of viral nucleic acids into the cell by arresting decapsulation. In addition, anionic properties of the polysaccharides may also reduce infection by limiting interaction between cells and virus. It has been proposed that the infection process of tobacco mosaic virus in part relies on an attraction between cellular anionic phosphate groups and cationic amino groups on the viral capsid. Supplying anionic polysaccharide could overwhelm such an 
interaction and thus suppress the rate of infection (Sano, 1999). Recalling the effect that methylation had on activity, a mode of action of this sort makes sense. For a large part, the anionic charge on polysaccharides comes from an abundance of hydroxyl groups. If these are methylated the polysaccharides would lose their anionic charge and consequently any mode of action dependent on it.

Despite the popularity of this charge mediated mode of action, there is strong evidence that it may not be the only antiviral effect that polysaccharides exert. In the past 8 years several studies have found polysaccharides to elicit plant defences and induce systemic acquired resistance (SAR) to crop pathogens (Klarzynski et al., 2000; Mercier et al., 2001; Kovalenko et al., 1993). Some algal polysaccharides, for example laminarin, are capable of mimicking natural elicitors, which upon recognition at the surface of the host cell stimulate the expression of plant defence genes (Mercier et al., 2001). The end result includes thicker cellwalls, production of phytoalexins, host hydrolyases and inhibitors of pathogen hydrolyases. These effects appear to be widespread, having been induced in assays using wheat, soyabean, alfalfa and tobacco. To date most studies have focused on testing resistance to the two most costly crop pathogens, fungi and viruses (Klarzynski et al., 2000; Mercier et al., 2001; Kovalenko et al., 1993). Although only laminarin and mannan sulphates, not alginate, have been implicated in systemic acquired resistance, the possibility of SAR as an additional mode of action is intriguing. 


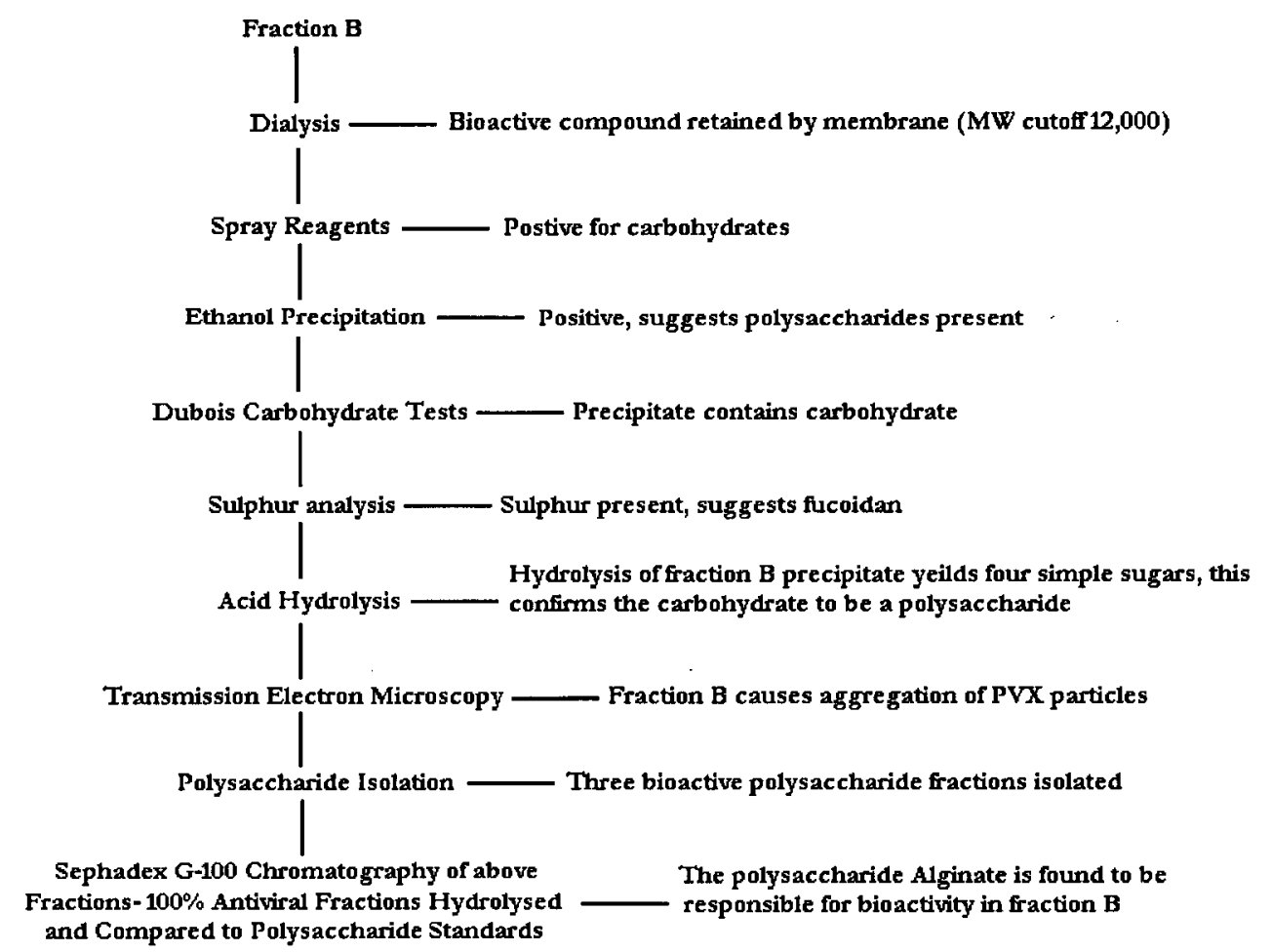

Figure 3.11: Summary of methods and results from the characterization of Fraction B.

\section{Fraction B Summary}

Isolation of alginate from Fucus gardneri and its identification as an antiviral agent against potato virus $\mathrm{X}$ is a first for plant virology. This is also the first screening of algae to look at the phytochemistry of antiviral activity in plant system. Initial indications that fucoidan is involved in antiviral activity have proven to be incorrect; however the finding that fucoidan stimulates infection is nonetheless interesting. In retrospect fraction $\mathrm{B}$ appears to have been an assemblage of molecules including alginate, laminarin and fucoidan. Transmission electron microscopy gave clear indications that alginate's antiviral mode of action relates to promoting aggregation of virus particles. Understanding the modes of action involved in alginate's antiviral effect, particularly possible modulation of plant defences, presents an excellent research opportunity. 


\section{SUMMARY AND CONCLUSIONS}

In this research project, marine algae from coastal British Columbia were examined for compounds with bioactivity against the plant virus, potato virus $\mathrm{X}$. Overall this project contributed to existing knowledge in this and related fields in several ways. This is the first study to evaluate New World algal species for compounds with potential for plant virus chemotherapy. Over thirty species were evaluated for bioactivity against potato virus $\mathrm{X}$, extracts from six algal species (Fucus gardneri, Alaria nana, Ralfsia sp., Codium fragile, Fragillaria oceanica, Egregia menziesil) strongly inhibit PVX infectivity. The disproportionate representation of Heterokont species in these most antiviral extracts was unexpected and deserves further evaluation. Of these six species, it is the first time that Fucus gardneri, Ralfsia sp. and Fragilaria oceanica have been reported as sources of antiviral agents.

Phytochemical analysis has lead to isolation protocols and the identification of one of the primary antiviral constituents in Fucus gardneri. Crude extracts of $F$. gardneri undoubtedly were the most potent in preliminary antiviral screening and dilution experiments. Fractionation of the crude extract using partitioning, column chromatography and a variety of other separation protocols resulted in the isolation of two bioactive fractions. Antiviral activity of the lower molecular weight fraction (A) was the result of phenolic and maybe amino-based compounds that have yet to be positively identified. Phytochemical analysis of the higher molecular weight fraction (B) resulted in the isolation and identification of the polysaccharide alginate as the source of bioactivity. Alginate inhibited potato virus $\mathrm{X}$ infectivity dramatically, and preliminary electron microscopy studies of crude alginate extracts suggests the antiviral mode of action to be related to virus particle aggregation. To date most antiviral research relating to polysaccharides has focused on synthetic, animal or red algal polysaccharides with little work evaluating the potential of brown algal polysaccharides (Witvrouw 
and De Clercq, 1997). Follow-up work on alginate's mode(s) of action, particularly focusing on possible induction of plant defences may yield exciting results.

As was found in the screening of $F$. vesiculosus for anti-HIV activity (Beress et al., 1993), bioassay guided fractionation of $F$. gardneri in the present study found bioactivity to be broadly distributed in a large number of fractions. Phytochemical analysis leaves little doubt that several antiviral compounds or a group of like compounds remain unidentified. The isolation and identification of these, as well bioactivity from the other top five extracts highlighted during screening, may be well worth the effort. Local lesion assays evaluating the antiviral activity of alginate and fractions of A showed no signs of phytotoxicity. Given the water solubility, natural abundance and apparent biologically benign nature of these antiviral agents, future work should include their evaluation in traditional chemotherapy protocols and determination of their effect against established infection. 


\section{BIBLIOGRAPHY}

Baba, M., Snoeck, R., Pauwels, R. and De Clercq, E. 1988. Sulphated polysaccharides are potent and selective inhibitors of various enveloped viruses, including herpes simplex virus, cytomegalovirus, vesicular stomatitis virus and human immunodeficiency virus. Antimicrobial Agents and Chemotherapy 32: 1742-1745.

Beutler, J.A., McKee, T.C., Fuller, R.W., Tischler, M., Cardellina II, J.H., Snader, K.M., McCloud, T.G. and Boyd, M.R. 1993. Frequent occurrence of HIVinhibitory sulphated polysaccharides in marine invertebrates. Antiviral Chemistry and Chemotherapy 4: 167-172.

Beress, A., Wassermann, O., Tahhan, S., Bruhn, T., Beress, L., Kraiselburd, E.N. Gonzalez, L.V. de Motta, G.E. and Chevez, P.I. 1993. A new procedure for the isolation of anti-HIV compounds (polysaccharides and polyphenols) from the marine alga Fucus vesiculosus. Journal of Natural Products 56: 478-488. [Erratum appears in Journal of Natural Products (1996). 59: 552.]

Blunden G., and Gordon S. 1986. Betaines and their sulphonio analogues in marine algae. In: Progress in Phycological Research. Volume 4. Edited by: F.E. Round and D.J. Chapman. Biopress Ltd., Bristol. pp. 39-80.

Boyd, M.R., Gustafson, K.R., Mcmahon, J.B., Shoemaker, R.H., O'Keffe, B.R., Mori, T., Gulakowski, R.J., Wu, L., Rivera, M.I., Laurencot, C.M., Currens, M.J., Cardellina, J.H., Buckheit, R.W., Nara, P.L., Pannell, L.K., Sowder, R.C., and Henderson, L.E. 1997. Discovery of cyanovirin-N, a novel human immunodeficiency virus-inactivating protein that binds viral surface envelope glycoprotien gp120: potential application is microcide development. Antimicrobial Agents and Chemotherapy 41: 1521-1530.

Collins, R.A., Ng, T.B., Fong, W.P., Wan, C.C., and Yeung, H.W. 1998. Removal of polyphenolic compounds from aqueous plant extracts using polyamide minicolumns. Biochemistry and Molecular Biology International 45: 791-796.

Dubois, M., Gilles, K.A., Hamilton, J.K., Reber, P.A. and Smith, F. 1956. Colorimetric method for determination of sugars and related substances. Analytical Chemistry 28: 350-356. 
Eppley, R. W. 1958. Sodium exclusion and potassium retention by the red marine alga, Porphyra perforata. Journal of General Physiology 41: 901-911.

Gregson, R. P. and Daly, J. J. 1982. Polyhydroxy biphenyl ethers from the brown alga Cystophora congesta. Australian Journal of Chemistry 35: 649-657.

Gonzalez, M.E., Alarcon, B. and Carrasco, L. 1987. Polysaccharides as antiviral agents: Antiviral activity of carrageenan. Antimicrobial Agents and Chemotherapy 31: 1388-1393.

Haslam, E. 1998. Practical Polyphenolics - from Structure to Molecular Recognition and Physiological Action. Cambridge University Press. pp. 1-80.

Haug, A. 1974. Chemistry and biochemistry of algal cell-wall polysaccharides. In: Biochemistry Series One. Vol. 11 Plant Biochemistry. Edited by: Northcote, D.H. University Park Press. pp. 51-88.

Higgins, C.F. and Payne, J.W. 1982. Plant peptides. In: Nucleic Acids and Proteins in Plants I: Structure, Biochemistry and Physiology of Proteins. Edited by: Boulter, D., and Parthier, B. Springer-Verlag. New York. Pages. pp.438-442.

Hilp, M. 1988. Oxygen flask combustion method of the euoprean pharmacopedia ph. Eur III. Comments on the determination of sulfur in heparin salts. Archiv der Pharmazie (Weinheim) 321: 313-314.

Hudson, J.B., Kim J.H., Lee M.K., Hong Y.K., and DeWreede, R.E. 1999a. Multiple antivital activities in extracts of seaweed from British Columbia. Pharmaceutical Biology 37: 300-306.

Hudson, J.B., Kim, J.H., Lee, M.K., DeWreede, R.E., and Hong, Y.K. 1999b. Antiviral compounds in extracts of Korean seaweeds: evidence for multiple activities. Journal of Applied Phycology 10: 427-434.

Jenkins, T., Blunden, G., Wu, Y., Hankins, S.D., and Gabrielson, B.O. 1998. Are the reductions in nematode attack on plants treated with seaweed extracts the result of stimulation of the formaldehyde cycle? Acta Biologica Hungarica 49:421-427.

Jin, H.J., Kim, J.H, Sohn, C.H. Dewreede, R.E., Choi, T.J. and Towers, G.H.N. 1997. Inhibition of Taq DNA polymerase by seaweed extracts from British Columbia. Journal of Applied Phycology 9:383-388. 
Kim, J.H., Hudson J.B., Haung A.M., Bannister K., Jin H., Choi T.J., Towers G.H.N., Hong Y.K., and DeWreede R.E. 1997. Biological activities of seaweed extracts form British Columbia, Canada, and Korea. I. Antiviral activity. Canadian Journal of Botany 75: 1656-1660.

King County Washington, Department of Natural resources, Water and Land resources division. $2001 \mathrm{http://splash.metrokc.gov/wlr/waterres/marine/algae.-}$ $\underline{\text { htm }}$

Klarzynski, O., Plesse, B., Joubert, J.M., Yvin, J.C., Kopp, M., Kloareg, B., Fritig, B. 2000. Linear beta-1,3 glucans are elicitors of defense responses in tobacco. Plant Physiology 124: 1027-1037.

Kovalenko, A.G., Grabina, T.D., Kolesnik, L.V., Didenko, L.F., Oleschenko, L.T., Olevinskaya, Z.M., and Telegeeva, T.A. 1993. Virus resistance induced with mannan sulphates in hypersensitive host plants. Journal of Phytopathology 137: 133-147.

Lee, R. E. 1999. Phycology $3^{\text {rd }}$ Edition. Cambridge University Press. pp. 481-540.

Lehninger, A.L., Nelson, D.L. and Cox, M.M. 1993. Principles of Biochemistry. Worth Publishers. New York. pp. 293-310.

Liu, Q.R., Lopez-Corcura, B., Mandiyan, S., Nelson, H., Nelson, N., 1993. Molecular characterization of four pharmacologically distinct $\alpha$-aminobutyric acid transporters in mouse brain. Journal of Biological Chemistry 268: 2106-2112.

Mann, J. 1987. Secondary Metabolism. Oxford University Press. New York. pp. 1-25.

McInnes, A.G., Ragan, M.A., Smith, D.G., and Walter, J.A. 1985. The high molecular weight polyphloroglucinols of the marine brown alga Fucus vesiculosus $\mathrm{L} .{ }^{1} \mathrm{H}$ and ${ }^{13} \mathrm{C}$ nuclear magnetic resonance spectroscopy. Canadian Journal of Chemistry 63:304-312.

Mercier, L., Lafitte, C., Borderies, G., Briand, X., Esquerre-Tugaye, M.T., Fournier, J. 2001. The algal polysaccharide carrageenans can act as an elicitor of plant defence. New Phytologist 149:43-51. 
Mian, J. A. and Percival E. 1973. Carbohydrates of the brown seaweeds Himanthalia lorea, Bifurcaria bifurcata and Padina pavonia. Carbohydrate Research 26:133-146.

Moen, L.K. and Clark, G.F. 1993. A novel reverse transcriptase inhibitor from Fucus Vesiculosus. International Conference on AIDS 9: 145-161.

Nakashima, H., Kido, Y., Kobayashi, N., Motoki, Y., Neushel, M., and Yamamoto, N. 1987. Purification and characterization of an avian myeloblatosis and human immunodeficiency virus reverse transcriptase inhibitor, sulphated polysaccharides extracted from sea algae. Antimicrobial Agents and Chemotherapy 31: 1524-1528.

O'Clair R. M. and Lindstrom S. C. 2000. North Pacific Seaweeds. Plant Press. Auke Bay. pp. 1-114.

Osusky, M., Zhou, G., Osuska L., Hancock, R.E., Kay, W.W., and Misra, S. 2000. Transgenic plants expressing cationic peptide chimeras exhibit broadspectrum resistance to phytopathogens. Nature Biotechnology 18: 1162-1166.

Painter, T.J. 1983. Algal polysaccharides. In: The Polysaccharides Vol. II. Edited by: Aspinall, G.O. Academic Press. pp. 196-275.

Percival, E. 1970. Algal polysaccharides. In: The Carbohydrates: Chemistry and Biochemistry Vol. IIB $2^{\text {nd }}$ Edition. Edited by: Pigman, W. and Horton, D. Academic Press. New York. pp. 537-568.

Percival E. and McDowell, R.H. 1967. Chemistry and enzymology of marine algal polysaccharides. Academic Press. New York. pp. 157-164.

Prasad, C. 1995. Bioactive cyclic dipeptides. Peptides 16:151-164.

Ragan, M.A. 1985. The high molecular weight polyphloroglucinols of the marine brown alga Fucus vesiculosus L.: degradative analysis. Canadian Journal of Chemistry 63: 294-303.

Ragan, M. A. and Craigie, J.S. 1976. Physodes and phenolic compounds of brown algae. Isolation and characterization of phloroglucinol polymers from Fucus vesiculosus (L.). Canadian Journal of Biochemistry 54: 66-73. 
Ragan, M.A. and Glombitza, K.W. 1986. Phlorotannins, brown algal polyphenols. In: Progress in Phycological Research Vol. 4. Edited by: F.E. Round and D.J. Chapman Biopress. Bristol. pp. 81-110.

Schaeffer, D.J. and Krylov V.S. 2000. Anti-HIV activity of extracts and compounds from algae and cyanobacteria. Ecotoxicology and Environmental Safety 45: 208-227.

Sano Y. 1995. Antiviral activity of polysaccharides against infection of tobacco mosaic-virus. Macromolecular Symposia 99: 239-242.

Sano, Y. 1999. Antiviral activity of alginate against infection by tobacco mosaic virus. Carbohydrate Polymers 38: 183-186.

Stahl, E. 1969. Thin-Layer Chromatography - a Laboratory Handbook. Translated by Ashworth M.R.F. Springer-Verlag. New York. pp. 855-906.

Tuomi, J., Ilvessalo, H., Niemela, P., Siren, S. and Jormalainen, V. 1989. Withinplant variation in phenolic content and toughness of the brown alga Fucus vesiculosus L. Botanica Marina 32: 505-509.

Valls, R. and Piovetti, L. 1995. The chemistry of the Cystoseiraceae (Fucales: Phaeophyceae): chemotaxonmic relationships. Biochemical Systematics and Ecology 23: 723-745.

Van Den Hoek, C., Mann, D.G. and Jahns, H. M. 1995. Algae: an Introduction to Phycology. Cambridge University Press. Cambridge. pp. 103-168.

Waterman, P.G. and Mole, S. 1994. Analysis of Phenolic Plant Metabolites. Blackwell Scientific Publications. pp. 1-43.

Whistler, R.L. and Smart, C. L. 1953. Polysaccharide Chemistry. Academic Press. New York. pp. 5-45.

Witvrouw, M. and De Clercq, E. 1997. Sulfated polysaccharides extracted from sea algae as potential antiviral drugs. General Pharmacology 29: 497-511.

Zhang, L., Dhillon, P., Yan, H., Framer, S. and Hancock, R.E. 2000. Interaction of bacterial cationic peptide antibiotics with outer and cytoplasmic membranes of Pseudomonas aeruginosa. Antimicrobial Agents \& Chemotherapy 44: 33173321. 


\section{APPENDIX 1}

Table A1.1: Percent inhibition of PVX infectivity of chalcones and crude extracts not discussed in thesis. Chalcones courtesy of Jeffery Harborne assayed at $20 \mu \mathrm{g} / \mathrm{ml}$, extracts assayed at $10 \mathrm{mg} / \mathrm{ml}$.

\begin{tabular}{|l|c|c|}
\hline Extract & $\begin{array}{c}\text { Average \% } \\
\text { PVX } \\
\text { inhibition }\end{array}$ & $\begin{array}{c} \pm \text { Standard } \\
\text { Error }\end{array}$ \\
\hline Wild Potato HAW1452 Stoloniferum & -60.7 & \pm 82.7 \\
\hline Wild Potato HJ'T349 Chacoense & 34.0 & \pm 21.7 \\
\hline 4'-methoxy 2'3-dihydroxy chalcone $^{\prime}$ & -63.9 & \pm 55.5 \\
\hline 2',4',3,4,-tetrahydroxy Chalcone (Butein) $^{\prime}$-'-102.2 & \pm 34.1 \\
\hline 4'-hydroxy 3,4,dimethoxy chalcone & -9.9 & \pm 31.8 \\
\hline 6,3',4' trihydroxy aurone (Sulfuretin) & 14.0 & \pm 41.1 \\
\hline 2'-hydroxy 4',6',2,4 tetramethoxy chalcone & -81.2 & \pm 50.1 \\
\hline 7-hydroxy-4'-methoxy chalcone & -100.6 & \pm 107.6 \\
\hline 3',4' dimethoxy flavone & -24.8 & \pm 35.4 \\
\hline 2'-hydroxy 3,4,5-trimethoxy dibenzoyl methane & -113.1 & \pm 65.1 \\
\hline 2'-hydroxy 4',6',2,5-tetramethoxy chalcone & -68.8 & \pm 50.3 \\
\hline 2'-hydroxy 3,4-dimethoxy chalcone & 5.4 & \pm 14.7 \\
\hline 2'4 diOH Chalcone & -60.5 & \pm 24.9 \\
\hline Acacetin & -13.0 & \pm 41.0 \\
\hline Devil's Club whole plant methanol extract & -1.5 & \pm 8.1 \\
\hline Feverfew surface dichloromethane extraction** & -22.9 & \pm 5.8 \\
\hline Feverfew whole plant methanol extract & 7.3 & \pm 3.6 \\
\hline Lomatium dissecticum root methanol extract & 98.4 & \pm 32.8 \\
\hline Lomatium dissecticum shoot methanol extract & 14.4 & \pm 3.0 \\
\hline Lomatium geyeri root methanol extract & 6.2 & \pm 10.4 \\
\hline Lomatium geyeri shoot methanol extract & 0.4 & \pm 8.4 \\
\hline Lomatium macrocarpum root methanol extract & 9.9 & \pm 17.5 \\
\hline $\begin{array}{l}\text { Lomatium macrocarpum shoot methanol } \\
\text { extract }\end{array}$ & -22.4 & \pm 35.4 \\
\hline Hypericum perforatum whole plant* & 100.0 & \pm 0 \\
\hline
\end{tabular}

*Extract provided by Andres Lopez **Extract provided by Kevin Usher. 